University of Louisville

ThinkIR: The University of Louisville's Institutional Repository

Electronic Theses and Dissertations

$12-2010$

\title{
The trickster, the griot, and the goddess : optimal consciousness in the works of Ntozake Shange, Kara Walker and India. Arie.
}

Tiffany D. Caesar 1985-

University of Louisville

Follow this and additional works at: https://ir.library.louisville.edu/etd

\section{Recommended Citation}

Caesar, Tiffany D. 1985-, "The trickster, the griot, and the goddess : optimal consciousness in the works of Ntozake Shange, Kara Walker and India. Arie." (2010). Electronic Theses and Dissertations. Paper 193. https://doi.org/10.18297/etd/193

This Master's Thesis is brought to you for free and open access by ThinkIR: The University of Louisville's Institutional Repository. It has been accepted for inclusion in Electronic Theses and Dissertations by an authorized administrator of ThinkIR: The University of Louisville's Institutional Repository. This title appears here courtesy of the author, who has retained all other copyrights. For more information, please contact thinkir@louisville.edu. 
THE TRICKSTER, THE GRIOT, and THE GODDESS...: OPTIMAL CONCIOUSNESS IN THE WORKS OF NTOZAKE SHANGE, KARA WALKER, AND INDIA. ARIE

\author{
By \\ Tiffany D. Caesar \\ B.A., Truman State University, 2008
}

\author{
A Thesis \\ Submitted To The Faculty of The \\ College of Arts and Sciences of The University of Louisville \\ In Partial Fulfillment of the Requirements \\ For the Degree of \\ Master of Arts \\ Department of Pan-African Studies \\ University of Louisville \\ Louisville, Kentucky
}

December 2010 
Copyright 2010 by Tiffany Caesar

All Rights Reserved 

THE TRICKSTER, THE GRIOT, and THE GODDESS: :

OPTIMAL CONCIOUSNESS IN THE WORKS OF NTOZAKE SHANGE, KARA

WALKER, AND INDIA: ARIE

\author{
By \\ Tiffany Caesar \\ B.A., Truman State Univerity, 2008
}

A Thesis Approved On

August 25; 2010

by The Following Thesis Committes:

Thesil Director 


\section{DEDICATION}

This thesis is dedicated to my mom, whose spirit has been with me through the whole process.

Thank you mom, you were the first artist I knew. 


\section{ACKNOWLEDGEMENTS}

I would like to thank my mentor, professor, and thesis director Dr. Martin for her continuous patience and motivation through my Master's of Pan-African Studies and thesis process. I have been very fortunate to have someone like her to guide me-thanks for helping me find my rhythm. To Dr. Thomas, you have always opened your office to me and rubbed my back with your encouraging words. You also allowed me to explore new creative avenues, thank you! Young, Black, and Fabulous- Dr. Story you wear the garb of professor very well; thank you for pushing me to be independent in my study and equipping me with the confidence to know that I can achieve. I am forever grateful for the call I received from Dr. Talley to tell me I was accepted to the Master's of PanAfrican Studies program; she has also been a wonderful mentor and motivator throughout my experience at the University of Louisville. I also appreciate my wonderful cohort Anita Thomas, Ciara Pierce, and Willie Wright; my PAS experience could not have happened without you all. I also acknowledge all the people who helped me edit; Lauren at the writing center, you were god sent and all my friends who helped: Ade Aderibigbe, Danielle Leveston, Triza Cox, Jacqueline Thompson, Jennifer Oladipo, and more! I would also like to thank my Granny, Nana, and Grandfather for their continuous motivation. DeMarcus Caesar, my little brother, you keep your sister in check. If I did not 
mention you, know that you are appreciated. I am forever grateful for the energy and visions I receive from my Ancestors and Guardian Spirits, Ashe! 


\begin{abstract}
THE TRICKSTER, THE GRIOT, and THE GODDESS...: OPTIMAL CONCIOUSNESS IN THE WORKS OF NTOZAKE SHANGE, KARA WALKER, AND INDIA. ARIE
\end{abstract}

\author{
Tiffany Caesar
}

August, 252010

The creative expressions of three black women artists--Ntozake Shange, Kara Walker, and India. Arie--are explored using optimal consciousness-an Afrocentric framework by Linda James Myers. This concept advocates that the role of the artist is to provide art that raises the consciousness of the people. An illustration of optimal consciousness will be demonstrated in their works by using the following criteria presented in the theory: authenticity, the fusion of sacred and secular, and positive interpersonal relationships. The creative works utilized for this analysis are Shange's choreopoem For Colored Girls Who Have Considered Suicide When The Rainbow is Enuf, Walker's silhouette narrative Gone, An Historical Romance of Civil War as it Occurred Between the Dusky Thighs of One Young Negress and Her Heart, and Arie's song "Video." 
TABLE OF CONTENTS

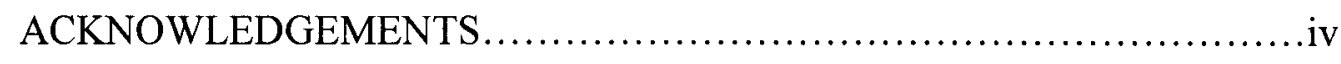

ABSTRACT ...............................................................

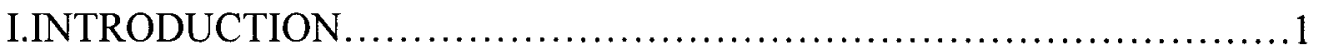

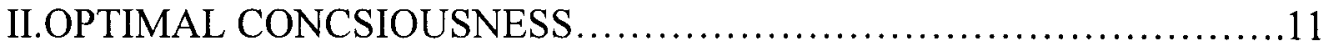

III. TRADITIONAL AFRICAN ART AND BLACK

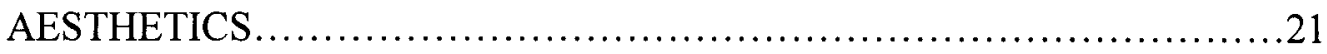

IV. A SURVEY OF BLACK AESTHETICS FROM 1920s UNTIL

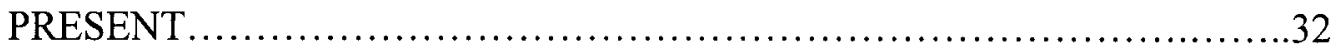

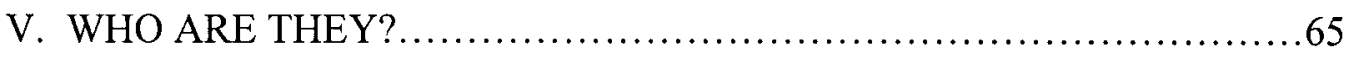

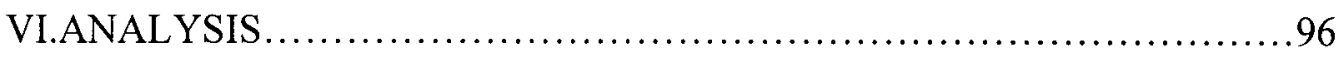

VII.CONCLUSION....................................................... 122

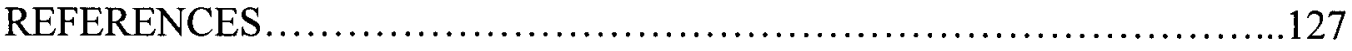

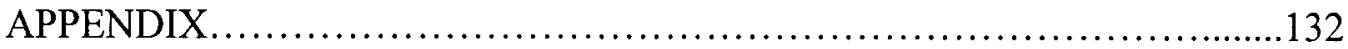

CURRICULUM

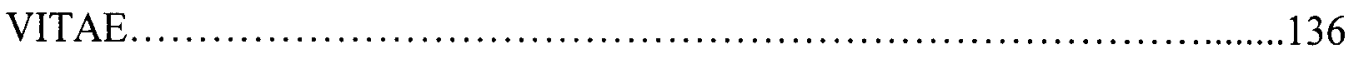




\section{CHAPTER I}

\section{INTRODUCTION}

This case study demonstrates how three African American women artists-Ntozake Shange, Kara Walker, and India. Arie- earliest works represent Linda James Myers's Afrocentric theory of optimal consciousness. The basis of this discussion is another Afrocentric theory, the Nzuri Model by Kariamu Welsh-Asante, which accents the importance of the collaborative efforts of the critic, artist, and patron. The creative works utilized for this analysis are Shange's choreopoem For Colored Girls Who Have Considered Suicide When The Rainbow is Enuf, Walker's silhouette narrative Gone, An Historical Romance of Civil War as it Occurred Between the Dusky Thighs of One Young Negress and Her Heart, and Arie's song "Video."

Following Introduction in Chapter 1, Chapter II Optimal Consciousness discusses the theoretical framework applied to these artists' works created by Afrocentric psychologist and cultural critic Linda James Myers. Optimal consciousness within the framework of Black aesthetics suggests that the role of the artist is to provide art that raises the consciousness of the people. The Black artist has to create work that is functional to the society to evoke change. The three criteria within optimal consciousness used for this study are authenticity, the fusion of the sacred and secular, and positive interpersonal relationships. In discussing authenticity, Myers emphasizes that "[t]rue artisans feel empowered by what is within. Technicians replicate the externalized productions of others" ("Optimal Consciousness" 181). Originality of the artist is a 
crucial aspect of optimal consciousness. Linda James Myers argues for a more holistic approach when it comes to viewing art. Instead of viewing it as either sacred or secular, one should "acknowledge the sacred in the secular ... and make the secular sacred" (181). This aspect of the theory allows the study to demonstrate how Shange, Walker, and Arie's works transcend the segmentation of the sacred and secular, and infuses both. Positive interpersonal relationships are the last criteria of optimal consciousness examined; it stresses the activity of communication that includes the artist, audience, and the artistry. Myers further extrapolates, "[a]n optimal Afrocentric perception would acknowledge the multiplicity of roles that both the communicator and listener play as the dialogue continues. If the conversation is to be the best possible, both must actively participate" (181). In order for there to be a positive interpersonal relationship, the audiences of the artist's work have to "[l]earn to be free" and let the energy of the art move them to react (181). This call and response strategy allows an unconstrained fluidity within the communication.

In collaboration with optimal consciousness, the Nzuri Model values the relationship of the critic, artist, and patron promote a collective space for functional criticism. Each member of this triad must be centered in an Afrocentric worldview so that their analyses are grounded in the same context. As stated, "[t]here has to be a common denominator so that the aesthetic is expanded, documented and preserved" (WelshAsante 172). With feedback coming from sources that fathom the worldview of the artist, the art is improved and the creator can grow. By acknowledging the interconnectedness of the roles of the researcher and critic, artist, and patron--the criticism of the artistry is 
enhanced. This concept of the Nzuri Model is further discussed in Chapter III Black Aesthetics and also the perspective from which this research is written.

Chapter III also familiarizes the reader with the traditional views of art from Africa and the impact slavery had on it. Also there will be a survey of other theoretical frameworks on Black aesthetics in America. It is a challenge to evaluate and discuss Black art if analyzed in the Eurocentric traditions. Myers states that "[t]he black aesthetic emerges from a cultural frame of reference, the complete antithesis to that of mainstream America" ("Optimal Consciousness" 181). She also confirms that "[f]rom ancient times within African cultures the role of the artist has been one of elevating the consciousness of the people" (Myers 178).

Black scholar and author Hoyt Fuller affirms that "the black aesthetic is corrective, a means of helping black people out of the polluted mainstream of Americanism" (178). Yet when the majority of the songs or movies presented on Black culture are drenched in stereotypes of an uneducated, over-sexualized, drug-addicted people who are unconscious of their surroundings, one wonders if there is contemporary art that is "corrective" for the Black community.

With this study, there is data that confirms there is still art that has been created within the last forty years that is corrective for the people. The Black artists presented here provide art that raises the consciousness of their audience and allows them a space for "identifying, fractioning out, and rejecting the absurdities" of the dominant culture (178). A great way to help the Black community reject these falsified perceptions, is to present images and symbols that are authentic representations of black people; hence the importance of the black artist. Shange, Walker, and Arie provide a type of creativity often 
seen as extinct. Welsh-Asante and Myers reason that the emulation of dominant culture by current Black artists is the cause of this artistic identity crisis. In this way, there is a critical necessity for the Black culture to use art to motivate, educate, inform, and in essence raise the consciousness of this vulnerable population.

The idea of Black art as a corrective, educational, or motivational tool for the black community has been commonly seen throughout the history of Blacks in America. Chapter IV A Survey Of Black Aesthetics From 1920s Until Present will discuss the Harlem Renaissance, Black Arts, and Hip Hop Movements. This chapter provides a history of Black aesthetics in America while discussing specific social and political contexts which will better situate the three artists of this study. The Harlem Renaissance of the 1920s-1930s has been considered one of the earliest, well-documented explosions of Black art in America. Within this time period, there is the creation of the New Negro who is described as someone who has agency in his or her life with higher education and more militancy (Painter 190). Artists like Langston Hughes, Zora Neale Hurston, and Claude Mckay are able to speak their minds using language to spark change and contribute to a unique Black aesthetic that was motivating to the community. Though the Harlem Renaissance capitalized on their white patrons who indulged in the creativity of these Black artists, the Black Arts Movement of the 1960s did not; it paralleled to the Black Power Movement. Both were characterized as being self-conscious, selfgenerating, and self-sustaining; it took Dubois's phrase "For Us By Us" to another platform (Karenga 489). The work of Nikki Giovanni, Imamu Amiri Baraka, and Sonia Sanchez sparked a movement that instilled within their viewers and listeners an immense amount of Black pride. Yet in the 1980s a new cultural movement drawing on this rich 
artistic history and pride came to the forefront: Hip Hop. This younger generation reaped the benefits of the battles won in the past through events like the Civil Rights Movement; they possess an attitude of empowerment and entitlement. Though Hip Hop has been commonly associated with rap music, it includes graffiti, dancing, fashion, and politics. This new generation of Blacks used-and continue to use-all these forms within Hip-Hop to create change. Even within contemporary rap music, the first Black president was highly revered in Young Jeezy's song "My President Is Black" showing Hip Hop's political edge while former President George W. Bush was criticized in a song called "Hell No We Ain't All Right!" by Public Enemy. These Black cultural movements aid in the understanding of the history of black artistry in America. There are other Black cultural movements; however, these are the ones that have contributed to or affected the artistry of Shange, Walker, and Arie.

Chapter V Who Are They? gives a concise description of Shange, Walker, and Arie's background. A brief discussion of how each artist represents a modern day manifestation of common African archetypes seen within Africa and the disapora such as the Orisha Oya, Trickster, and Griot provides texture to this research. An Orisha is a deity among the Yoruba of West Africa. There are several hundred orisha, one of which is Oya. She has many manifestations, like wind, fire, the buffalo, and the River Niger (Gleason 2). In describing this female warrior and outspoken god, or goddess, scholar Judith Gleason states "Oya is the goddess of edges, of the dynamic interplay between surfaces, of transformation from one state of being to another" (2). When Shange creates art, she goes to war, armed with her creativity. She also has many manifestations such as a dancer, playwright, poet, scholar, and more. Using the Zulu language, Paulette 
Williams changed her name to Ntozake Shange. Her name now means "she who comes with her own things" and "she who walks like a lion" (Anderlini 85). She is the creator of For Colored Girls Who Have Considered Suicide When The Rainbow Is Enuf, one of the first platforms that openly discussed the issues of Black women with no remorse. Shange embraces her feminine energy, just like Oya.

The trickster is an archetype seen throughout West Africa and America, you never know what the trickster is up to; he or she is a master of illusions called by various names such as Esu, Legba, Brer rabbit, or devil. The trickster can be a "deceiver, thief, parricide, cannibal, inventor, creator, benefactor, magician, perpetrator of obscene acts" or Kara Walker (Pelton 7). When depicting racial issues of the antebellum South, viewers do not know whose side she is on, the slave or the master. The trickster "shows himself in a baffling array of mythical masks" (5). One of the masks for Walker is The Negress which will be further explored in later chapters.

Walker shocked the art world when at a very tender age of 27 she won the MacArthur Genius Award which was accompanied by a $\$ 500,000$ grant, for her controversial silhouettes. Her images of the antebellum South through black silhouettes have told many stories, with each eye taking their own interpretation. Walker seems to recapture slavery's true essence by literally putting in the missing pieces in her artwork.

The griot is known as the holder of traditions, taking the knowledge of the people and passing it down. They embody the qualities of a historian and storyteller (Hale 18). Sometimes called praise-singers, words are the main tool of choice in which they create songs, tales, and epics (18). Griots are highly reverenced and also assist in diplomacy as well as instrumental music (18). They are able to present the past history of the culture 
which can help in making political decisions. There is always a lesson to be learned in the lyrics of India. Arie as she strums her guitar. Her songs are full of morals, values, and positivity that encourage the community. Arie possesses the griot's qualities, exemplifying a great storyteller and keeper of traditions. Though she is the youngest artist who is analyzed, her work is just as important by encouraging people to love themselves to telling men to respect women. Her positive outlook allowed her to bounce back after being nominated for several Grammys and not winning any for her song, "Video." The following year, she won a Grammy for "Simple Things" in which lyrics placed higher value on sunshine than glitter and gold. Her lyrics defy contemporary music, which often focuses on superficial objects such as money, cars, and houses, in favor of more unconventional lyrics that are infused with gratitude and ancestral homage.

Chapter VI is the analysis of Shange's choreopoem For Colored Girls Who Have Considered Suicide When The Rainbow is Enuf, Walker's silhouette narrative Gone, A Historical Romance of Civil War as it Occurred Between the Dusky Thighs of One Young Negress and Her Heart, and Arie's song "Video" using Linda James Myers's optimal consciousness. This chapter, describes how each work represents the three criteria in optimal consciousness: authenticity, the sacred and secular, and positive interpersonal relationships.

The choreopoem created by Shange includes spoken word, dance, and music. It is a space in which women could come together to share their pain, joy, and life circumstances-a healing place. Critics have said that "Shange's theatre pieces work to raise consciousness individually, socially, and artistically, and center around the complex notions of identity politics" (Lester 5). Walker provides a whimsical, mythological, 
truthful, callous and historical account of the antebellum South which goes beyond the obvious racial tension using black paper and white walls. Her silhouettes have also been compared to an illustrated book (Wagner 93). Arie's song provides a counter discussion to popular songs that emphasize that a woman's beauty is obtained through material possession and physical perfection. By showing how she loves herself regardless of societal images, she is able to help other women embrace their true selves. Those brief descriptions of the works of Shange, Walker, and Arie are looked at in depth to reveal the three criteria of optimal consciousness.

Chapter VII Conclusion brings the elements of the discussion together and presents the researchers observations and experience with the artists and their works. For example, this chapter, explores the fact that these African American women artist all changed their names, grew up in middle class America, and were ostracized in some way by contemporary society. This chapter also posits numerous branches of future research involving Black women and art, neo-soul, and Black cultural movements.

\section{LIMITATIONS}

The major limitation of this research was applying the criteria of optimal consciousness to three artists working in three different styles and genres: - a playwright, singer, and visual artist. Each artist had a unique way of demonstrating their authenticity, fusion of sacred and secular, and exhibiting positive interpersonal relationship that had to be analyzed differently. However, the perspective of optimal consciousness allowed some points of similarity to be identified. Analyzing artists from a similar genre would have added more depth to the discussion but reduce some of the comparative analysis. 
Also, providing equal analysis of three different artists and works posed as a challenge. Though, there were examples of optimal consciousness in all their works, the quality and quantity in each varied. For example, the section in chapter VI Analysis discussing authenticity has the most data because there were more examples of how the artists' crafts were authentic. On the other hand, the segment on the fusion of the sacred and secular, Shange's choreopoem provides more illustrations of this criterion than the other artists work. In addition, since only one work was analyzed from each artist, there were some limitations in how much discussion could be led about the artists work and style.

There were also limitations in the section on positive interpersonal relations. Though Linda James Myers provided examples on interpersonal relationships, more research on the psychological aspects of optimal consciousness would have allowed a more well-rounded critical view. However, incorporating the literature from another discipline within the time frame of this research was not feasible and will be addressed in future research.

Out of all the artists, the most laborious person to find research literature on was India. Arie. Since she is the youngest artist and is primarily embedded in popular culture, there has been little written about her work. She has not been academically canonized like Shange and Walker, contributing to the limiting sources on her artistry. By relying on interviews, websites, magazines and other non-traditional sources, there is a scholarly foundation in process about her background. There was also a lack of information on her musical genre, considered "neo-soul". 
By using optimal consciousness, this research strives to reveal new ideas about Black women artists and their crafts, as well as inspire others to think critically about current artists today. Another goal is to demonstrate how three African American female artists across genres shift the consciousness of their viewers and listeners to one of positive awareness. This research is not only relevant within many disciplines such as Women's Studies, Black Studies, Art, History, but it is even for the person who wants to know more about the spiritual qualities of art.

As a person who embodies not only the researcher, but an artist, critic, and patron, there is an even more intimate connection with the work of these artists. As an artist, you have the ability to share the joys of creativity with Shange, Walker, and Arie because of the shared insight that goes hand in hand with the process and result of creating. As a patron of all of these artists, you can enjoy the art in which they form. The reward of this criticism will be an Affirmation or Ashe, which is recognition of the vitality in their work (16). The Ashe principle is described as the "affirmation of one's traditions through reinforcement, reliance, enhancement and retrieval in the artistic product," but the simplest form of it means gratitude (13). By analyzing their work from the personal experience of an artist, patron, and critic, it gives these artists gratitude; Ashe Ntozake Shange, Ashe Kara Walker, Ashe India. Arie. 


\section{CHAPTER II}

\section{OPTIMAL CONSCIOUSNESS}

From ancient times within African cultures, the role of the artist has been one of elevating the consciousness of the people. Providing them signs and symbols of the higher forms of

life and human functioning, the aesthetician encouraged, educated and reflected those aspects of being to which humanity must aspire to fulfill its purpose (Myers, "Optimal Consciousness" 178).

The theoretical framework of optimal consciousness is developed by Afrocentric psychologist Linda James Myers who maintains that the responsibility of the artist is to create art that is purposeful for the society. Optimal consciousness, in relation to Black art, is the ability for the artist to create works that address an issue in society while presenting it in a way that raises audience/community awareness of consciousness. The idea of consciousness-raising can be used interchangeably with shifting energy, in that they both create change in the viewer. In an Afrocentric worldview "one acquires knowledge through symbolic imagery and rhythm" (Myers, Optimal Psychology 13). The artist provides the imagery to give knowledge that will inform the self, whether that is by using Shange's choreopoem, Walker's silhouette, or India's song. The artists of this study, Shange, Walker, and Arie, each provide this imagery through their artworks. It is crucial that artists create work that shifts people's energy to maximize their existence and knowledge or raise their consciousness. 
This is essential because one of the functions of the Black aesthetic, according to the theory of optimal consciousness, is to evoke positive change. Linda James Myers uses two key words in describing her theory: optimal and consciousness; optimal is the "maximally positive experience in a holistic way" (Optimal Psychology 4). The optimal allows us to figure the best way to address an issue. Consciousness is defined as the "permeating essence or pervasive energy, or spirit" which is the key factor in the optimal conceptual thought (13). Consciousness is energy, it is spirit, and it is a manifestation of you. Spirit "refers to that permeating essence we come to know in an extrasensory fashion" (i.e. energy/consciousness/God) (12). Consciousness and spirit are interchangeable, and it is felt outside of the normal five senses. It is challenging to measure spirit/consciousness in comparison to the other senses and it seems to fall under the category of the unknown. According to Mutombo Nkulu-N'Sengha, an African scholar, in an African epistemology there are the supernatural, the natural, and the paranormal paths to knowledge (68). The paranormal paths skirt the edge of the unknown. However, spirit is one of the elements that is frequently discussed within an African world view and is essential to optimal consciousness. A spiritual experience is subjective to the individual; it is accepted as true based on his or her knowledge.

Functionality is an important element of optimal consciousness. It is a challenging obstacle to create Black art when there is pressure from the dominant society to create art that has been defined by the stereotypical ideas and images of the Black race. Myers further discusses the conflict of evaluating Black culture under the Eurocentric worldviews, 
This [African] worldview is the complete antithesis to the one of dominant socialization in U.S. society. Yet much of African American culture and experience is examined and judged from the perspective of the dominant culture, rather than the Afrocentric perspective which it reflects more closely. As a consequence, serious errors of transubstantiation are made, and African American culture and the black aesthetic are often misunderstood or undervalued ("Optimal Consciousness" 179).

It is a constant battle for an artist to create art that is sustaining for the community when "[b]eing a part of the culture, the mold is set for African Americans, with little opportunity for developing their own indigenous cultural frame of reference" (180). Myers suggests that now Black aesthetics are "at risk of total destruction, being co-opted into a lifeless art form characterized by the political economy of the "music industry,"' television industry, beauty industry, and the list can go and on (180). When there is a constant promotion of violence, sex, hate, money, and instant gratification, where is there room for the elevation of the consciousness? Myers states, "[t]he role of the artist changes from that of an enlightened leader to that of a slick showman, the art form from a mechanism of moral uplift ta a reinforcer of lower passions" (179). She attests that "a society that perpetuates racism and sexism to the point of institutionalization is teaching its adherents to think in a very limited, superficial manner - sub-optimally, to say the least" ( Myers, Optimal Psychology 9). She also states, Mass media further reinforces racism/sexism by changing history to suit the desired image of the dominant group and presenting stereotypic, negative images 
of non-dominant groups, reinforcing the notion that in our society only the reality of a certain people is valid (9).

The black aesthetic can only be recaptured and revitalized through "the elevation of human and spiritual networks, which can only come about through education and raising the consciousness of the people about who they are, their history and culture, and what they represent as spiritual beings"(Myers, Optimal Consciousness, 181). Myers provides an example on how music was able to raise the consciousness of enslaved Black people. She mentions that music was a "non-verbal expression of people's consciousness" that specifically carried a spiritual element allowing them to transcend their inhumane situation as slaves (179). Music shifted their energy so that they could endure their circumstances, allowing Blacks to stay encouraged through the horrid 400 years of harsh servitude (179). The rhythms of the diverse Africans enhanced their survival once they crossed the Atlantic. This is illustrated in their usage of music to communicate and run away as discussed in Chapter III. As discussed later in chapter III, Traditional African Art and Black Aesthetic Theories. Rhythms are seen as a source of the spirit. Throughout the African American experience there is a constant pattern showing how music, spoken word, theatre, art, dance and other performance vehicles were used to aid them in times of turmoil or celebrates times of joy which will be covered in Chapter $I V$.

Myers refers to Larry Neal's ideas on black aesthetics as an example of the optimal conceptual thinking. Neal points out that, “...the ideas the people put forth as representing their history and experience, their mythology, as spirit worship, veneration of the ancestors" (179). The putting forth of these ideas causes a transformation that allows the art to be a manifestation of the "Infinite Spirit, Ntu, The Force" or whatever a 
person calls their ultimate power. According to Neal, rhythm is the foundational force of the creative principle that can be experienced through vibes or vibration, an energy relationship between entities has been phrased in musical terminology as "on the One," "In the groove," or "swinging" (179). Neal recognizes that these creative forces carry an energy that is transformative not only to the artist, but the audience members as well. Optimal consciousness is not only experienced in music, but also in theatre, art, poetry, stories and more. It has been described as "a unity which contains and transcends all opposites, rather than segmented, dichotomous, either/or form" (180). This thesis will show how three creative vehicles the choreopoem, silhouette, and song negotiate their rhythms differently, but are still able to impact the spirit.

The fusion of the sacred and secular is one of the components of optimal consciousnesses. The encouragement of the diunital ${ }^{1}$ - when complementary opposites coexist- such as the spiritual and secular, has been documented in traditional African cultures. According to Myers, this fusion has the ability to provide a remedy to the negative effects the Eurocentric worldview has had on the African mind. Optimal consciousness recognizes the erroneousness of the Eurocentric epistemology and attempts to alleviate the manacles of the cultural brainwashing placed on the descendants of Africans. Myers states, "[t]he intellectual imperialism of Western patriarchy has proven to be viciously intolerant of any perspective that breaks the bonds of its conceptual incarceration" (Optimal Psychology 4). Viewing the sacred and secular as a unit versus separate entities assists in breaking the conceptual bondage of Blacks in America.

\footnotetext{
${ }^{1}$ Brown, Timothy J. "Reaffirming African American Cultural Values: Tupac Shakur's Greatest Hits As A Musical Autobiography." Western Journal of Black Studies (2005).
} 
In describing the spiritual element of jazz or the fusion of the sacred and the secular, she discusses how the jazz musician goes into a zone, in which he/she is led by the spirit, especially seen in improvisation (Myers, "Optimal Consciousness" 181). The audience can see and experience the communication that the musician is having with his or allowing the viewers and listeners to respond as they are affected (181). Through this idea one can realize that "[h]uman kind is a spiritual force not apart from infinite spirit, infinite energy, infinite consciousness, and/or God (supreme or ultimate reality)" (Myers, Optimal Psychology 8). Myers further describes the process,

For example, from the beginning, the beauty of jazz resided in union of the infinite Spirit and the musicians. To the extent the musician was able to let go of his/her individual ego and separateness and allow the infinite Spirit to manifest through him/her and his/her instrument, magic was made ("Optimal Consciousness").

However, the transcendent element of jazz--the union of the infinite spirit and musician-has been lost to the dissection of it into scientific terms of counting and measuring, though it is extremely hard to write a jazz improvisation because of the constant spontaneity and spiritual element (181). Jazz improvisation is not to be written or contained, it is to be a free spiritual expression, however " $[t]$ he epistemological position of mainstream America, assuming external knowledge and knowing by counting and measuring, translates in the music arena to "reading" music (181)." Then if you cannot read music, and you are spiritually gifted to play by ear, your talent is seen as inferior. That is why she affirms, "[t]rue artisans feel empowered by what is within. Technicians 
replicate the externalized productions of others" (181). This means that an artist's work is his or her to their experience and no one else's.

If Black art is not put into context using theories or perspectives that are informed by the Black community, black art will continually be under attack by a society that does not have or understand the cultural framework. It is crucial that there are black art critics to discuss black art from an Afrocentric perspective which places a distinct value back on the importance of conscious black art. If not, Black artists will be misinformed about what to create, being affected by the norms of society, which is external, hostile, or disapproving of their experiences. When the artist is seen as "the teacher innovator and mythology maker," it is important that he/she pull from internal experiences that are familiar to their surroundings (Welsh-Asante 15). Otherwise the viewer or audience will be misinformed about the knowledge they are gaining about themselves, which can be fatal. According to Welsh-Asante the "patron or audience responds by supporting the artist and hopefully promoting understanding and appreciation." However, if the work of the artist is self/community negating, this can be detrimental to the audience or patron who supports it. Black art judged and created within an Afrocentric worldview is necessary to provide alternative art that is not destructive to the self and community. That is why the coordinated efforts of the critic, artist, and patron are essential promoting work that is transformative, and corrective, and that raises the consciousness.

According to Myers, the energy that Neal discusses can be traced back to the Egyptian Mystery System as well as other types of spiritual energies based on the experience and the collective race memory. In the Egyptian Mystery System emphasis was placed on all that was good; the idea of goodness was a tool to aid in the elevation of 
consciousness. However with slavery, new challenges to goodness were introduced (Myers, "Optimal Consciousness" 179). Now within the African American collective consciousness the residue of the Middle Passage is exhibited through landlessness and claustrophobia, as well as the isolation of urbanization with the ghettos (179). As the African in America endured numerous trials and tribulations, these experiences became a part of cultural memory. Cultural memory from the African American experience can also include acts of lynching, Jim Crow Laws, syphilis experiments, the raping of black women, police brutalities, feelings of neglect during natural disasters such as Hurricane Katrina and more. Stories, songs, plays, music, and poems have been created to express the feelings of the black people experiencing these cruelties. These expressions in one way or another affirm the situation. The black artist is responsible for not only recording the good, but also the bad. Myers explains this balance noting that "[a] transmutation and synthesis takes places as the collective folk consciousness seeks to integrate the new, yet sustain the essential" (180). The challenge is not to saturate the art with just the bad, but to balance it with the good, and allow knowledge to be gained from it somehow. Though this is occurring, there are still artists who are creating work that is functional to the society. Larry Neal calls it a neo-mythology in which the "[s]hamans are now preachers, poets, rhythm and blues singers, jazz and pop musicians, rock and rollers and so on" (180).

Myers provides three ways for a Black aesthetic to reach optimal consciousness. The artist's work has to be authentic, described as the "higher refined energies directly from the spirit" while inauthentic is a "lower more dense replication and imitation of the spirit" (181). If you are observing a true black aesthetic that is authentic, you can see and 
feel the conversation that the artist is having with God (higher being). As discussed earlier, this study is dealing with paranormal knowledge which skirts the edge of the unknown. The spiritual experience that an audience member may have is subjective; there is no list of rules that describes an individual's intimate divine encounter. Second, we must remove ourselves from the Eurocentric world view of segmentation of the sacred and secular. Myers states below,

We must further break out of the bonds of conceptual incarceration imposed by the intellectual imperialism of dominant culture, by no longer allowing the segmentation of ourselves, no longer allowing the segmentation of the so-called sacred and secular... acknowledge the sacred in the secular ("Optimal Consciousness" 182).

These ideas of separation are in conflict with optimal consciousness thought that "allows for the seeming opposites of the sacred (spirit) and the secular (matter) to be unified, contained, and transcended (also described as diunital)" (180). The third concept is to value positive interpersonal relationships. The importance of good communication skills and the understanding of the type of communications that exist are important in optimal consciousness. There exists an active participation within the interpersonal relationships that should be valued. The relationship can be between a woman and man or between characteristics like femininity and masculinity (Myers, Optimal Psychology 13). The interpersonal relationship is not limited to gender, but can also occur between Word/Music, Call/Response, word/Word, and listener/receiver (Myers, "Optimal Consciousness" 182). This is the analysis of the intricate relationships that can transpire between the webs of the artist, creative vehicle, audience, and spirit. Myers states, 
In order for the optimal legacy of our heritage to reach its potential, we must first learn to distinguish the authentic from the inauthentic, the essence from the illusion, the gold from the glitter and require it from our artisans. Optimal Afrocentric theory provides us the requisite frame of mind to accomplish this task, by supplying the assumptions and principles we must utilize within our conceptual system, to see clearly and understand, as theretofore our cultural heritage has been denied us and negated ("Optimal Consciousness" 181). Chapter IV demonstrates how the works of Shange, Walker, and Arie through authenticity, fusion of the sacred and secular, and positive interpersonal relationships manifest optimal consciousness. Optimal consciousness equips me with the tools to positively criticize the artists' abilities to create art from a context of relevancy. Optimal consciousness is also the point at which the triad of the critic/artist/ patron, proposed by Welsh-Asante, converges. The artist will know if he/she is making art that is functional for the society based on the response of the patrons. If the consciousness of the patron is not shifted, that is a reflection of the artist work. Simultaneously, the critic will always make sure the artist's work is incorporating necessary messages that are beneficial for the community by questioning and or encouraging the artist work. The theory of optimal consciousness provides a unique space in which all-the artist, patron, and critic-can co-exist together. 


\section{CHAPTER III}

\section{TRADITIONAL AFRICAN ART AND BLACK AESTHETICS}

In traditional African cultures "art is lived out; it is experienced intimately, it is expected and demanded" (Jegede 238-239). From that definition of traditional African art, there is a sense that art is for all people not just the elite. It is a functional and living element in the society. The purpose of art is to teach, criticize, uplift, or praise. When describing this phenomenon, scholar Jegede states that "art is integral to life and to man's well being [and]... is expressive of a people's world-view, and its absence creates an obvious but uncomfortable vacuum" (239). This illustrates the significance of the artist to the culture's history and to the motivation of the people's well being. Creative energies were directed toward the following: agriculture, religion, child bearing, leadership, encouragement, illness, celebrations, weddings, rites of passage, burials, hunting and more. Art encompassed the sacred and secular as discussed in the previous chapter. For example, the Bamana in Mali, whose diviner is called a chi wara, may advise the people to make masks and dance to evoke the spirits favor for plentiful crops (242). Agriculture was important to African communities and the people were aware that sufficient rain and other weather conditions were critical to their crops growing. The diviner was called upon to perform different ceremonies so that deities and spirits of nature were appeased and would assist them in having good crops for the season. 
Welsh-Asante express the interdependence of the artist and community as such, An artist "in the tradition" worked for the community and his or her task was considered a part of the divine order. An artist in African society does not view society as an impartial observer in order to create, rather society actively gives vision and perspective from which to express oneself (Welsh-Asante 2).

The usefulness of art can be seen also in the Yoruba people of Nigeria, West Africa. For example, twins were highly favored and the carvings of the Ibeji Twins were made to encourage procreation (Jegede 243). For rulers like the $o b a$ in the Yoruba culture, their beautifully crafted beaded crown was used to signify his leadership (243). The Ikenge sculpture encouraged "well being and prosperity" to many states in Nigeria especially, the Igbo people (243). Art was life, and just like people, it was a breathing organism a part of the community daily life. As Welsh-Asante mentions, "[d]istinction between society and artist and between spectators and performers are not linear and so rigidly separate. In traditional African society, the spectators and the artist are one. According to Fabre this is also true of the early African in America. When Africans were brought to the Americas during slavery, they found ways to practice their own customs and rituals that blurred the lines of the spectator and performer. This is seen in the communal activity of field singing. The preacher and the artist within the slave community were also seen as parallel because both were able to motivate the masses; this is also similar to traditional African culture when one thinks of the artist and the spiritual leader (Ife 37). Performance took on different manifestations. During slavery, music was critical to their survival, and in some cases their freedom. Music allowed blacks to escape the institution of slavery with songs like Swing Low, Sweet Chariot. While the whites thought it was 
just a spiritual song, Swing Low Sweet Chariot had a hidden message that helped slaves to freedom. It had hidden messages about the underground railroad that took slavery to freedom in the North (Welsh-Asante 2). Many instruments that originated in Africa were brought to the Americas by African slaves. These instruments include the banjo, balafone (xylophone), the musical bow, flutes, elephant tusk horn, clarinets (dududen), gongs, rattles, castanets, drums and more (Karenga 473). The drum, a direct link to African culture, was prohibited by the slave owners (Asante 54). Forms of artistic expression like singing and drumming were at one time banned during slavery for fear of rebellion by the whites (Karenga 473). Since the slaves could not use the drum, they created other ways to express percussion through tin cans, the hambone on the human body, and spoons (Asante 54). As we can see, Africans adapted in this new culture by incorporating new ideas in their aesthetic so that they could still express themselves. Art was not some worldly function, it encouraged the spirit. Spirituality has been acknowledged by most scholars in black art with the knowledge that "spirit cannot die, it cannot be measured, quantified, or seen" (Welsh-Ashante 11).

Though Africans were coming from all over the African continent to the Americas and languages and aesthetics were different, they were able to find some ways to communicate with each other in order to create a sense of cultural ties. One of the ways was through rhythms that contributed to the field holler during slavery and morphed into work songs, spirituals, blues, and jazz in the African American culture (Ife 36). Another was the ring shout that allowed African slaves to express a commonality amongst their cultural differences (44). Folklore within slavery can also be linked back to the trickster tales in traditional African culture (42). African folklore that was infused with the 
animals such as the jackal, hare, tortoise, and hyena became the fox, rabbit, turtle or terrapin and wolf because of the new American experience (Karenga 484). The types of folklore stories that existed were animal stories, legendary hero stories, human trickster stories, exaggeration stories, why stories, and tales of satire which were all found in the Americas and Africa (Karenga 484). Even slave burial services included dance, singing, and the symbol of the circle all of which were illustrations of African tradition. There were also celebrations for new crops that occurred during slavery which included dancing and singing, such as the agricultural ceremony that was also seen in Africa (43).

On both sides of the Atlantic, African art became an object of scrutiny under Eurocentric standards of aesthetics and was often misrepresented by white foreigners. Black art was labeled inferior because the European observers did not see anything that resembled something aesthetically beautiful according to their standards. African art was therefore labeled primitive and tribal (Jegede 239). Their masks, shrines, and assortment of sacred objects were considered fetish and pagan (239). These artworks were not seen as sacred objects which linked Africans to their ancestors or encouraged a healthy and prosperous life. This is due to the predominant Eurocentic aesthetic that was imperialistic and greatly subjected other forms of aesthetics that were considered foreign to the Eurocentric view (Welsh-Asante 6). Africa became known as the Dark Continent, void of anything that was good and intelligent. Though these societies continued to make art that was functional to their society, it was always in conflict with the Eurocentric ideas of aesthetics, both in Africa and the Americas. 
The Eurocentric definition of aesthetic is the "branch of philosophy that deals with beauty or the beautiful, especially in art, and with taste and standards of value in judging art" (Welsh-Asante 165). It is a linear view of art that focuses more on an outward appearance, superficial. Plato, the father of Greek philosophy, is known for incorporating these views of aesthetics into society. He is also known for the division of man into the rational and emotional, disrupting a cosmology that was once in harmony viewing man and society as whole (Ani).

With this rational objectification of the cosmos, art becomes something to be dissected by the rational mind. Museums were thus created to display artifacts and art in recognition of the past. These materials become an object of amusement, versus an element that was once critical to the society. However in traditional African culture, art was free and functional, not enclosed in a space like a museum. Art was meaningful to the society because the "process and function serve as organic institutions and consequently provide a temporal permanence" for art (Welsh-Asante 5). One may argue that the preservation of art was non-existent because it was created to be consumed and not just viewed.

Black artists and intellectuals have challenged Eurocentric ideologies by rejecting those ideas of creativity and tapping into their own reservoir of art founded on African principles. This occurred in the Harlem Renaissance, when African American artists are beginning to express their feelings openly about living in the prejudice society of America. Black intellectuals in America have looked back to the traditional views of African art as stated previously, to provide frameworks for black art to be judged. As Kariamu Welsh-Asante states, 
We have reclaimed ourselves, become reattached to the African source and refamiliarized ourselves with the theater, music, dances and art of Africa as they come straight from the continent. This reclamation is accomplished alongside the new African culture that has been spawned in America. The phenomenon that continues to take place is the synthesis, fusion and reconstruction that is a vital part of the African American aesthetic (xii).

Kariamu Welsh-Asante's framework is called the Nzuri Model. It was created as a manner to conceptualize the pan-African aesthetic which "aims at individualizing the common characteristics that occur in the African aesthetic" (1). In discussing the idea of a pan-African aesthetic she states that it "transcends geographical and ethnic boundaries and functions on certain commonalities..." (2). In discussing its functionality, she mentions that African art is "the conscious expression of the impression and experience, individual or collective, whether it is by memory or activity" (4). When there is an acknowledgement of the historical aesthetic tradition and motifs, it produces a victory of consciousness that incorporates "reclamation, redefinition, reconstruction, and eliminates the need for reactionary art forms" (6). Within the Nzuri Model she discusses three criteria for the aesthetics of the African people: spirit, rhythm, and creativity (4). The definition of the Nzuri Model is a "theory that regards perception and values as complimentary entities. It is the belief that good and beauty are interchangeable" (11). The core of her model is the spirit, rhythm, and creativity that are units of Ntu, the life fore or vital energy (11). Ntu is also described as the "infinite cosmological energy that permeates all beings and all things. Ntu joins everything and flows through everything" (11). There are also seven aspects used to criticize the art, which are meaning, ethos, 
motif, mode, function, method technique, and form (11). Lastly there are the principles of oral, ashe, and ehe as well as the Nommo Spiritual Mode that completes her theoretical framework for a pan-African aesthetic.

Dona Marimba Richards uses a Kiswahili term Kugusa Mtima (to touch the heart) as a replacement to the Eurocentric word and meaning of aesthetic to conceptualizing African Aesthetic and national consciousness (D. Richards 65). She also uses ikon instead of icon which will be seen throughout this chapter. She states that the "European discourse seeks to limit our understanding of ourselves (often succeeding) by imposing conceptions, terms and definitions which are based on the utamawazo (culturally structured thought) of the European tradition" (64). The word aesthetic, to her, is too limiting for an African world-view. Kugusa Mtima goes beyond "beauty" and "pleasure," while she expands it and places it into the context of the profound African understanding/experience of the universe" (65-66). Richards also states, "Kugusa Mtima deals with transcendence, transformation, human consciousness, and the power of a collective human will" (66). This reinforces the notion that art is life. Richard believes, by an illustration of "Kugusa Mtima such as rhythm, music, dance, song, poetry, myth and masks, we are able to create and alter our reality thereby altering our consciousness of that reality" (69). She links the idea of Kugusa Mtima with a national consciousness which she explains as a "political consciousness in which members of a group understand themselves as sharing a common destiny, based on shared cultural history and racial origin" (63). She describes consciousness as not only "biological/cognitive, but is also a personal/cultural/spiritual experience" (68). With the use Kugusa Mtima manifested in areas like art, symbol, and myth the creation, a national consciousness can occur to 
express and motivate the African identity (71). When inspired by your own cultural symbols, "The predilections for African design will automatically and naturally cause us to reject the artificially assimilated taste of colonial "aesthetic" (74). This idea goes with Linda James Myers, creator of optimal consciousness, “[t]ruth always sell..." because once the audience is awakened to the authentic message that the artist puts forth; they want to hear more (Myers, "Optimal Consciousness" 182 ).

In a similar vein, Afrocentric psychologist Linda James Myers theory of optimal consciousness expresses the importance that black art be functional, conscious-raising, and spiritually transcendent. Her ideas were explored in chapter II. From this brief discussion on traditional African Art and creativity during enslavement, as well as discussion of African centered aesthetics, African art is functional, communal, spiritually transcendent, and consciousness-raising. These are only a few of the theoretical frameworks on black art, Larry Neal, Paul Carter Harrison, and the Molettes are other people who have explored the theorization of black art. All there works explore aspects of black performance in Africa and the Diaspora.

They all understood black art needed to be explored because aesthetics can be used to describe and express the cultural temperament which can impact the people. Art is responsible for the cultural images that inform icons. For example, watermelon and fried chicken have become negative cultural ikons of African American people based on the stereotype that it was enjoyed by black people. Some rap music that glorifies the black woman's body, drugs, and crime have become cultural ikons as well. These ikons do not always have a positive impact on the culture or the viewer. That is why it is critical that there are artists in the black community who create work that challenges 
negative images that have been used for centuries to illustrate the black community. Dona Mariamba Richards states: "An image is an ikon when it becomes a forceful presentation of the national/cultural idea. It is a sensory presence defined by the collective vision and the collective self-image" (76).

When the ikons depict a primarily Eurocentric aesthetic it causes problems for those considered to be the "other" because their cultural symbols are not being acknowledged, and are negated because they do not embody the Eurocentric worldview. As Welsh-Asante states,

Clearly an aesthetic that puts a great emphasis on straight hair is going to present a problem for people with curly hair. An aesthetic that glorifies blonde hair and blue eyes consequently promotes blonde hair and blue eyes. A people who are naturally dark should not even hope for such a transformation. And therein lies the problem. An aesthetic defines and establishes culturally consistent elements and then enthrones standards based on the best historical and artistic examples (5).

On the other hand, as Richards states, "African American culture constitutes one of the most powerful elements for beauty and innovation in the American society" (xii). This signifies that, although Black art has been harshly criticized, it has also been immensely celebrated. Richards encourages Black artists to incorporate positive images of the Black community in their work so that positive ikons can be produced, "Afrocentrically our artists must help us to make the right choices by using African motifs in all that they do. We must surround ourselves and our children with African ikons, thereby developing an "authentic taste," inspired by the Kugusa Mtima-force of Africa" (D. Richards 74). 
Scholar Swindell notes that when Black aesthethics is considered inferior, dominant culture tries to control the output which "is [a] violation of the human spirit" (177). An example of this control factor is when improvisational jazz that is not supposed to be written because of the spontaneity of its nature, was written to be replicated. . Improvisational jazz is a free flowing expression of the jazz musician's spirit. As a Black artist, being conscious of your environment is knowing when your work is conforming to Eurocentric standards. The artist's creativity is informed by the power to define his or her own reality. This concept is the authenticity spoken of here and a key aspect of the Optimal Consciousness Theory. Richards suggests that if Black artists incorporate true cultural images in their work, positive ikons will be created which will help to combat the Eurocentric mentality that has handicapped so many Black people globally: "The predilection for African design will automatically and naturally cause us to reject the artificially assimilated taste of a colonial "aesthetic" (D. Richards 74).

Though it is important for the artist to create art that is viable for their community, there also needs to be someone to give it healthy criticism. Welsh-Asante states that “[p]articipation means not only affirmation of the performance process but acknowledgement of the skill, meaning and history...A sensibility and sensitivity is required in order to protect the artistic and consequently the aesthetic tradition" (WelshAsante 14). This will only enhance the artist and the society and encourage the artist to create work that is functional for the community (14). The art must be examined by the artist, the critic, and the patron (15). 
To challenge one to transform their minds through Black aesthetics is something that has been prevalent throughout Black culture and has manifested in different art forms as seen during slavery, The Harlem Renaissance, The Black Arts, and The Hip-Hop Movement. A historical account of how Black art has been a transformative element in other eras, such as in traditional African culture, follows this chapter. By acknowledging the past, a better understanding of Shange, Walker, and Arie will manifest. 


\section{CHAPTER IV}

\section{A SURVEY OF BLACK AESTHETICS FROM THE 1920S UNTIL PRESENT}

By exploring three major cultural explosions in Black history-the Harlem Renaissance and the Black Arts and the Hip Hop Movement—an illustration will show how there have been Black artist creating art that was functional, whether it was to motivate, educate, or agitate. If it was Langston Hughes commenting on the role of the Black artist during the Harlem Rennaissance, or Sonia Sanchez encouraging black pride in the afro-wearing days of the Black Arts Movement or Grandmaster Flash playing music for the graffiti artist during the Hip-Hop Era; This historical overview of Black aesthetics in America provides a foundation and context for the works of Shange, Walker, and Arie. It illustrates that Blacks artists were using optimal consciousness before the phrase was even conceived by making art that responded to social and political issues of their time period.

\section{Going North and the Harlem Renaissance}

The Harlem Renaissance of the 1920s-1930s is known as one of the earliest experiences of Black artist openly expressing their true sentiments in America. Harlem quickly became known as the "Negro Capital of the World" due to the significant amount of Blacks populating the area during the Great Migration (Takaki 353). Fleeing hardships in the South like lynching and low wages, African Americans came to the northern cities like Detroit, Cleveland, Chicago and New York for the gilded promise land located in the 
North (340-341). The time period between 1910 and 1920 has been likened to the Black Exodus because so many Blacks came from the South doubling the Black populations in these northern cities. African Americans were tired of being sharecroppers, victims of hate crimes, and wanted to be treated with respect (341). An estimated half of a million left the South during the First World War (Painter 190). Famous Black newspapers like the Chicago Defender and the Urban League's Opportunity urged southern Blacks to go North for a better life (Painter 190; Takaki 342). Factories needed people to work and the southern black population provided labor (Takaki 342; Painter 190). Southern Blacks went to places like Chicago due to the Illinois Central Railroad's easy access to small towns in Arkansas, Louisiana, and Mississippi (Takaki 348).

Upon arrival, Blacks received better jobs, wages, less discrimination, and safety from the southern terrorist acts like lynching (Painter 192). The North also offered southern Blacks with the means to a better education, right to vote, and freedom to use their creativity in the areas of art and music (189).

Blacks were developing a new attitude; it was a "new generation of blacks coming to age" that surpassed just the want for money (Takaki 344). This new Black population arising in the North and West was noted for their higher education, and militancy -- known as the "New Negro" (Painter 190). Southern whites felt the shift in the black's attitudes: 
White southerners frequently complained that this new generation of blacks was "worthless". Lacking the habits of "diligence, order, faithfulness" of those who had been born in slavery, they "rarely remain[ed] long enough under the supervision of any planter to allow him sufficient time to teach them (Takaki 344).

African Americans continued to move to the North, and could care less about what southern planters felt about their "New" attitude. Matter of fact, to this younger generation of blacks who were uprooting from the South to the North, slavery was considered "childhood tales" (Takaki 344).

As stated before, this Great Migration coincided with World War I. Although there were a lot of hardships for Black soldiers, there were also outlets for Black soldiers to express themselves creatively through jazz bands. Black soldiers' jazz bands traveled internationally spreading their music (Painter 198). Bill "Bojangles" Robinson, who was famous for his role in Shirley Temple's movie The Little Colonel, was originally a part of the $369^{\text {th }}$ Infantry from New York that was stationed in Paris (198). The Black aesthetic was already spreading nationally and internationally with jazz.

Yet when the war ended, it was not a welcoming environment for the soldiers. The summer of 1919 was coined the "Red Summer" by black writer James Weldon Johnson because of the black blood that was shed (199). Race riots occurred in twenty-six cities because whites were not able to accept blacks with a uniform coming home and demanding respect (199). 
Claude McKay's famous poem, If We Must Die explores the sentiments of the black man fighting back, instead of accepting the treatment of a second class citizen (201). McKay was conscious of what was going on in the society and wrote a poem that embodied that energy to motivate the people to continue in the struggle for equality, he was an artist using optimal consciousness before the idea had a term. His work was functional to the society, and through his eyes he wrote authentically what he saw and his sentiments. He was a part of a group of conscious artists who wrote about the situations of blacks in the 1920s. Black art added to the creation of the "New Negro" that separately became known as the Harlem Renaissance which will be discussed later.

The northern experience was not as easy as it was thought to be by southern Blacks who were migrating. Many Blacks coming from the South soon came to learn that places like Chicago and New York hoarded the same racial sentiments as the South. On the other hand those racial sentiments fueled Blacks in Chicago to start their own businesses and organizations like insurance companies, stores, banks, and churches (Takaki 352). So though Blacks were getting resistance, they knew in order to empower themselves they had to fight back and stick together (352). Black solidarity and ethnic enterprise transpired in Chicago known as the "Black Metropolis," and Harlem, New York "The Negro Capital".

Harlem was not only a thriving place economically and socially for blacks, it was diverse in its black population. An influx of immigrants from the Caribbean added another flare to Harlem. It was stated that "[b]etween 1910 and 1920, 33,464 people of African descent immigrated to the United States" (Painter 192). It was also stated that "[i]n 1920, the total of 73,803 foreign born blacks in the United States came 
overwhelmingly from the Americas, notably the West Indies and Cuba" (192). The New Negro was "international, multi-lingual, and ethically heterogeneous" (192). This is very important to remember in our observance of the Harlem Renaissance, because it was not consisting of only African Americans, but blacks from Jamaica, Cuba, and other places who added to the Harlem flavor.

One man in particular, Marcus Garvey brought his Black Nationalism sentiments to Harlem, stirring up some trouble and providing others with a new way of thinking about blackness (Takaki 355). Marcus Garvey is said to have created the largest Black Nationalist movement in black history (263). He founded the Universal Negro Improvement Association first in Jamaica, then in Philadelphia, Cincinnati, Detroit, and New York (355-356). Garvey, influenced by the ideologies of Booker T. Washington, created the UNIA to unite all the "Negro peoples of the world and establish a black nation in Africa" (355). The UNIA motto was "Up, You Mighty Race, You Can Accomplish What You Will!"'(Painter 203). The UNIA even had colors associated with this Black Nationalist movement "[r]ed symbolized the blood of the race, black their color, and green the greatness of Africa's future" (Takaki 356). Marcus Garvey was prolific in his ability to gain black support to assist him in his "Back To Africa" plans. He created the Black Star Line through the UNIA, a shipping company that would allow Blacks to trade all around the world and assist in creating a Black nation in Africa (356). It would link the three major Black populated places together -- United States, West Indies and Africa (Painter 204). The UNIA had a ship, a church, women's group, laborers, marchers, police force and more (204). It is stated that "[s]ome 40, 000 blacks bought 155,510 shares amounting to three-quarters of a million dollars" (Takaki 357). 
Some other famous blacks from the West Indies were Harlem Renaissance writers Cyril Briggs and Claude McKay:

While there was a political uproar occurring with Marcus Garvey, there was also a Black Arts Movement happening simultaneously known as the Harlem Renaissance. One of the most well-known artists of this time, Langston Hughes, called this period beginning in the 1920s "The New Negro Renaissance" (Takaki 357). Harlem was a place that had many venues where one could enjoy the diverse forms of black entertainment through music, dance, poetry, theatre, and other creative activities. It was also home to many wealthy patrons of Black art (Painter 206). Newspapers like the Opportunity and the Crisis gave literary awards as a way to boost creativity in the Black community (206). Also organizations like The Harmon Foundation provided funding for Black artist to create work (211). Songs like Lift Every Voice and Sing by the Weldon Brothers becomes a Black national anthem though it was written and composed several decades earlier (206). Black music during the Harlem Renaissance served to uplift the community and to heal it from the ongoing discrimination and the southern terrorism that existed. These artists were inspired by their circumstances and wrote songs, plays, music, poems and more to express their experiences. The artist was a reflected events in the society.

Even the leader of the $369^{\text {th }}$ Infantry Band, James Reese Europe, was, “...more firmly convinced than ever that Negros should write Negro Music..." he continued "We won France by playing music which was ours... The music of our race springs from the soil" (207). Black artists believed that it was their right to make art for the people. There were artists like Ma Rainey making music specifically geared towards the black population. There was also the black musical Shuffle Along by Flourney Miller and 
Aubrey Lytel gracing Broadway Theatres (207). Marion Anderson entered the scene by winning the coveted New York Philharmonic singing competition in 1925 (208). There were also notable black visual artists of this time period like Aaron Douglas who used African motifs throughout his work and a sculptor named Augusta Savage (211).

Race leaders like W.E.B Du Bois, Jessie Fauset, Walter White, and James Weldon Johnson encouraged the flourishing of Black art during this time period (209). Also publishers were taking an interest in black literature by authors like Claude McKay, Zora Neal Hurston, Jean Toomer, and Langston Hughes (209).

Alaine Locke published the New Negro--an anthology of poems, essays, and visual art from the Harlem Renaissance (209). Also Arthur A. Schomburg, an avid collector of Black literature and one of the founders of the American Negro Academy, had his collection bought by the New York Public Library (210). The Schomburg collection consisted of "five thousand books, three thousand manuscripts, and two thousand artworks" (210). This contributed to the Black intellectual movement that coincided with the Harlem Renaissance. It was led by the older Black generation like $\mathrm{Du}$ Bois and Alaine Locke, but continued by the younger generation seen in Hughes and Hurston (210). Before Black history was dominated by whites, during the 1920 s there was an increase of Black scholarship created by Black intellectuals on the rise (210).

However, Blacks were not the only ones filling these cabarets and night clubs, whites would come to Harlem at night in throngs to experience the "colorful, exotic, spontaneous, sensuous, and lively" adventures (Takaki 358). Also there was a young group of Black intellectual artists coming from middle class families, and good educational backgrounds whose ideas gave fuel to the Harlem Renaissance (358). The 
black artists would go to Harlem to find inspiration for their creative works, "[d]rawing their inspiration and materials from black folk culture, they created literature that rebelled against Middletown America" (358).

The artist of the Harlem Renaissances discussed issues that ranged from Black identity to cultural ideologies to Black folklore as exhibited in music, stories, art, and dance. Langston Hughes famous essay The Negro Artist and The Racial Mountain provided his thoughts on how a Black artist should be proud of being Black and should not try to separate their race from their craft (359). However Zora Neale Hurston ideas on how the Black artist should be viewed was different than Langston Hughes but so was Jean Toomer, they both found Hughes's concept of the "racial mountain" too simplistic, too one-dimensional" (366). Claude McKay's Home to Harlem, Jean Toomer's wrote Cane, and Zora Neale Hurston's Their Eyes Are Watching God all provide a glimpse of the diversity of the Black experience in America.

Zora Neale Hurston was one of the most celebrated women of the Harlem Renaissance, though there were others. Unfortunately during this time period, men were at the forefront or at least the ones who were discussed the most. She matured in an all Black town called Eatonville in Florida (364). She studied anthropology at Barnard in New York, and in Columbia under the renowned anthropologist Franz Boas (364). Her skills allowed her to return to her hometown of Eatonville to collect the stories and write Their Eyes Are Watching God. The Harlem Renaissance was seen as "stifling to Hurston as an artist and as a woman" (366). Zora Neale Hurston, had her own obstacles to overcome-just like Shange, Walker and Arie several decades later. Hurston use of "incorrect English" or black vernacular was criticized just as the work of contemporary 
artist Ntozake Shange. However, her work was authentic and spirit lead, while discussing the relationships that existed in her small town of Eatonville. She was an artist using optimal consciousness in her work by staying true to her authentic spirit.

Black artists decided to openly survey the Black experience and create art that was not censored. This was the beginning of an exploration of the Black culture through poetry, stories, music, art, and other vehicles of creativity. In describing the art of this creative movement Karenga states, "[t]he Harlem Renaissance produced race and socially conscious artists who reached back to Africa and the Black masses for a distinctive Black motif' (469). Artists designs like Aaron Douglas's work illustrated African and African American culture through the "African sculptures, jazz music, dance and geometric forms" (Aaron Douglas). Contemporary silhouette artist Kara Walker also pulls from the African American experience by using stereotypical images like the pickaninny, mammy, and sambo in her portraits of the antebellum South.

The blues lyrics of Mamie Smith in her hit Crazy Blues were heard throughout the clubs in Harlem, while contemporary neo-soul artist India. Arie pays homage to her ancestors like Mamie Smith for paving the way for her. So the Harlem Renaissance was a thriving time period for Black artists and some parallels can be seen between them and Shange, Arie, and Walker.

In 1929 the stock market crash on Wall Street, ushered in the Great Depression. This primarily ended the Harlem Renaissance, and many Blacks suffered by losing jobs and struggling economically. Many of the white patrons felt that Black art would be a great weapon used to end discrimination, however it continued and the Great Depression did not help (Painter 211). White patrons could no longer afford to finance the Black 
artists of the Harlem Renaissance. The Great Depression was so bad that some Blacks even tried to go back to the South only to be greeted by whites saying, "[n]o jobs for Niggers Until Every White Man Has a Job!" (Takaki 366). Blacks still continued to make art, but the next cultural explosion in Black communities would not be sponsored by whites. It would be self sufficient. However, this "explosion" the Black Arts Movement of the 1960 s, had its own set of challenges.

\section{Black Power and the Black Arts Movement}

The Black Arts Movement happened simultaneously with the Black Power Movement in the early 1960s to the mid-1970s. It was known as the "Second Black Renaissance" (Karenga 489). It was characterized as being self-consciousness, selfgenerating, self-determining, and self-sustaining; it took Dubois's phrase For Us By Us to another platform (489). Poets like Sonia Sanchez and Nikki Giovanni commented on black culture. In an essay by writer Julian Mayfield he comments on the power of words, "Malcom X...mastered the English language to shape words into bullets that would strike home at the center of his targets" (30). Also in 1975 John Killins wrote, "words are the writer's ammunition" (466). The artists of the Black Arts Movement used art as a weapon of mass destruction to fight against the racism that Blacks still experienced.

The ideas of Black Power began to resurface in 1965 with the emergence of Black Nationalist leader Malcom X (Marable 84). During the Black Power Movement Blacks focused on their African heritage more (Painter 317). "Black is Beautiful" became the mantra and was heard throughout the United States by Blacks illustrating their pride (317). Because of the slow response from government in addressing the needs of the Black community, and with the assassination of two major Black leaders Malcom X and 
Martin Luther King Jr. -- a more militant stance towards the government was brewing in the Black Community.

Malcom X's family descended from the West Indies, just like Black Nationalist leader Marcus Garvey and did not preach the same rhetoric of equality, as Martin Luther King, Jr. During the early years of Malcom X's political life, it was not odd to hear him say sentences such as, "[e]very white man in America, when he looks into a black man's eyes, should fall to his knees and say 'I'm sorry--my kind has committed history's greatest crime against your kind; will you give me the chance to atone?"' (Marable 85) He was a key member in the Nation of Islam whose fiery speeches caused migrants from the South to come to the North just to hear him speak (86). Just like in Harlem, in the early 1900s, many of the people who supported Marcus Garvey were Southern migrants as well fleeing the terrorism that existed in the South. By the mid 1960s, before his death, Malcom X had removed his ties from the Nation of Islam due to internal conflict and started the Organization of Afro-American Unity (OAAU), "a militant black nationalist force based primarily in New York City", just like Marcus Garvey's UNIA that was situated in Harlem (87).

While Malcom X was helping to resurrect a Black Nationalist movement that was seen in the early 1900s, he was in conflict with many of the other integrationists. Civil Rights advocate Bayard Rustin and others highly criticized Malcom X for his Black Nationalist ideas. However, Malcom X had caught the attention of the younger generation of Blacks that was exhibited in CORE and SNCC which will later form the later factions of Black Power organizations (88). 
Malcom X continued to stir up the youth of the 1960 s and even encouraged Blacks in their community to start "rifle clubs to defend the black community against police brutality and white vigilance violence" $(88)$. Later there was the uprising of the Black Panthers, a Black Nationalist organization that carried rifles to protect their community from police brutality.

Groups like CORE (Congress of Racial Equality) and SNCC (Student Nonviolent Coordinating Committee) that were comprised of Black and white members, began to lose their white members due to the rise of the Black Nationalist sentiments that were against the assistance of the white man helping in the Black struggle (88). However, Malcom X had enemies; it was believed that government officials and the Nation of Islam wanted him dead. In 1965 he was assassinated in Harlem while giving a speech to a Black audience (89). He had already placed a seed in the younger generation of Black Nationalists that would try to continue to create Black communities that were not affected by the dirty hands of the white man.

The 1960 s was also a decade of many race riots occurring all around the United States, with the most famous ones occurring in Watts and Compton, the most densely Black populated areas in Los Angeles (90). Race riots also occurred before the Harlem Renaissance after World War I ended. Detroit also had a huge race riot starting July 23, 1967, the graveness of the riots is Los Angeles and Detroit mentioned below, In Watts and Compton, the black districts of Los Angeles, black men and women took to the streets, attacking and burning white-owned property and institutions. The Watts rebellion left $\$ 40$ million in private property damage and 34 persons 
killed. Federal authorities ordered 15,000 state police and National Guardsmen into Detroit to quell that city's uprising in 1967 (90).

The race riots were coined as the "twentieth century slave revolts" by intellectuals who could not explain it as anything else (91). Though there were race riots, at the same time, the Black family annual income and Black employment was on the rise. The phrase "Black Power" emerged again, with a new thrust in the Black communities. It was believed that SNCC activist Willie Ricks was the key in promoting this idea (92). However the word was criticized as not being the best terminology by people like King (92).

One of SNCC leaders, Stokely Carmichael, after an arrest in Mississippi stated, "[ $t$ ]his is the twenty-seventh time I have been arrested. I ain't going to jail no more. What we gonna start saying now is "black power"' (92). Organizations like CORE and SNCC were no longer trying to get along with or include whites in their agenda in helping the Black man. It became the duty of the Black man to fix their own problems. For a long period, Black Power could not really be defined and the conservatives who were trying to understand it simplified it to mean Black capitalist power. Carmichael and a sociologist Charles V. Hamilton, who both wrote Black Power: The Politics of Liberation created this definition of it as,

A political framework and ideology which represents the last reasonable opportunity for this society to work out its racial problems short of prolonged destructive guerilla war...[Black Power will allow blacks] to exercise control over our lives, politically, economically and psychically. We will also contribute to the 
development of a viable large society...there is nothing unilateral about the movement to free black people. (Marable 94)

Carmichael and Hamilton also believed that "whites need[ed] to leave the black liberation struggle and reduce racism among whites" (Painter 319). It was a fight against institutional racism that provided Blacks with poor education, healthcare, and jobs while positioning their experience to those of third world nations (320). During this time period it was no longer appropriate to call Blacks "Negro," the name "Black," "African American," and "Afro-American" became the words of choice (320). It was encouraged that Blacks break away from the cultural terrorism placed on them by white society and to enhance their knowledge from a Black perspective (320). During this same time period in the Olympic Games were even impacted when John Carlos and Tommie Smith put their fists in the air, a sign of Black Power (332).

Those who associated Black Power with Black Capitalism defined it as a means to "ownership of apartments, ownership of homes, ownership of businesses, as well as equitable treatment of all people" (Marable 95). Nonetheless, the phrase Black Power spread like wild fire as racial propaganda. It also signified "black people defining positively, regardless of what white people thought" (Painter 318). This phrase wanted the world to know that they "would tend to themselves without paying heed to white people" (318). At the same time everyone in the Black community was not aboard this new idea, and there was a frequent clash between the older and younger generation. In 1966 legendary organizations like SCLC (Southern Christian Leadership Conference) and the NACCP (National Association for the Advancement of Coloured People) 
denounced the word usage of Black Power because they felt it was "misconstrued as an incitement to anti-white violence" (320).

At the same time of the Black Power sentiments, there was a war going on in Vietnam that caused tensions within the Black community (Marable 97). Though Blacks were in desegregated units unlike the ones in World War I, they were "poorly represented in the officers' ranks, grossly over-represented among personnel...[and] placed in "combat units" more often than middle-class whites, they also bore unfairly higher risks of being killed and wounded" (Marable 98). Though Blacks in the military were still experiencing racist treatment, they were organizing Black Power groups like the Black Mau Mau, Blackstone Rangers, and even the Black Panthers (Painter 337). SNCC was also considered first in denouncing the war efforts (Marable 98). Again the older generation like Dr. King and Whitney Young of the Civil Rights Movement sought to squash SNCC's open criticism (98).

Authors, poets, and representatives of black art started to speak against the war in Vietnam as well. James Baldwin declared, “[a] racist society can't but fight a racist war-this is the bitter truth. The assumptions acted on at home are also acted on abroad, and every American Negro knows this, for he, after the American Indian, was the first 'Viet Cong' victim" (99). S.E. Anderson wrote a poem called "Junglegrave" and Robert Hayden's poem "Words in the Morning Time" each criticized the war in Vietnam (100). King who was also against the Vietnam War, was soon assassinated. His death further fueled the Black Nationalist Movement even more.

There was also the emergence of the Black Panther Party for Self Defense in 1966 considered to be the "most provocative challenge to white liberal policies" (Painter 321) 
(Marable106). They were inspired by Franz Fanon, Mao Tse-Tung, and Che Guevara, all considered anti-imperialist authors (Painter 321). The group was founded by Bobby Seale and Huey P. Newton, two college students (Marable 106). The Black Panther Party had a Ten-Point Program that addressed what they wanted to achieve, some of their wants are included below:

1. We want freedom. We want power to determine the destiny of our black community.

2. We want full employment for our people.

3. We want an end to robbery by the white man of our black community.

4. We want decent housing, fit shelter for human beings. (107)

As stated earlier they also carried arms in the Black communities to protect themselves from the police (107). Towards the end of the 1960s the free breakfast program had served over twenty "thousand poor children in nineteen cities throughout the United States" (Painter 323).

The Black Panthers also provided transportation, healthcare, clothes, and a newspapers to the poor. They incorporated a free breakfast program for black children and gave free health services to residents (Marable 107). They were lead by mostly college educated Blacks from middle class families: Carmicheal and Baraka were graduates of Howard University, Nikki Giovanni went to Fisk University, and Karenga went to the University of California (108). This is similar to the Harlem Renaissance, when all the artists and intellectuals of the time were college educated Blacks from middle class rebelling. 
All these issues occurring in the 1960s and early 1970s sparked what has been called the Black nationalist renaissance or the second renaissance, "a tremendous outpouring of literary criticism, poetry, music and art, all of which served to reinforce Black Power and the uneven nationalist movement, in politics" (103). Malcom X encouraged a "cultural revolution to unbrainwash an entire people" (Painter 324). During this time period there was a "cultural regeneration as a vital means toward black liberation" (325). The Black Panthers' usage of guns in the communities inspired artists "to create images of black warrior heroes defending the black community" (321). For example the piece entitled the Wives of Shango named after the Yoruba deity of thunder "showed his glamorous, well-armed wives in Afro hairstyles, mini-dresses, and bandoleers of bullets (321). Black Visual artist, Archibald Motley Jr. created The First One Hundred Years: He Amongst You Who Is Without Sin Shall Cast the First Stone: Forgive Them Father They Know Not What They Do that showed the body-less heads of President John F. Kennedy and Martin Luther King Jr. (328). The American flag became a symbol of "black people's oppression" (333). A painting titled Deathmakers illustrates white skeleton police officers carrying a Black corpse with the American flag in the background (333).

Poets who gained their careers after the Harlem Renaissance like Gwendolyn Brooks, Dudley Randall, and Margaret Walker served as "patrons and inspiration to the younger artist" (Marable103). The Black World edited by Hoyt W. Fuller promoted black poets and playwrights such as Sonia Sanchez who wrote the famous poem We a BaddDDD People, Naomi Madgett author of Star by Star, Don L. Lee wrote Black Pride, and more (104). Two of the most influential artists of this time period were poets Nikki 
Giovanni and Leroi Jones (Imamu Amiri Baraka) (104). While writing poetry and plays, Baraka created the Spirit House, a place for black arts and culture in Newark (104). He expressed "Black Art Is Change, It Must Force Change, It Must Be Change" (Painter 338). This directly connects with optimal consciousness affirmation that the role of the artist is to elevate the consciousness of their audience. In further describing his poetry, Baraka's poetry uses black English as the national language of African Americans. For his black art relates to the people in black communities, not academics or literary critics. It uses black people's words and reflects their values, speaking as they speak about lives in poverty that may not be aesthetically pretty (339).

Larry Neal became one of the prime theorists of Black aesthetics during this tumultuous time period. In his chart called Some Reflections of the Black Aesthetic he discusses some of the important elements within Black Art. Through mythology, manifestations, and key concepts, he illustrates a Black aesthetic. Neal begins by discussing the original mythology that was seen through the spirit worship, Orishas, ancestors and show how that was manifested in the Sambo, gospel songs and juba once in the Americas (Neal 13). He discusses a Neo-Mythology that includes the preachers, poets, blues singers, and mackdaddies and how that carried over in contemporary dances, fashion, and strolls (13). Neal mentions the History As Unitary Myth that includes important Black historical figures and folklore characters like Nat Turner, Brer' Rabbit, High John the Conquer, Signifying Monkey, Malcom X, Garvey and more (15). As far as concepts he explains race memory as "[r]hythm as an expression of race memory; rhythm as a basic creative principle..." (13). He mentions the Middle Passage as being terror, 
landlessness, and claustrophobia in our race memory (13). In Transmutation and Synthesis he illustrates the dances of race memory "transmitted through the collected folk consciousness" described as the folk spirit in the Harlem Renaissance (13). These dances were the Funky Butt, Stomp, Jump Jim Crow, Watusi, Grind, twist, jitterbug and slow drag (13). His next section is called Blues/God Tone As Meaning and Memory in which he acknowledges "[s]ound as racial memory, primeval" (14). Within that section he mentions Call and Response, word as energy, and the fusion of the sacred and secular in Blues "perceived as an emanation outside of man, but yet a manifestation of his being/reality" (14). The last idea he describes is the Black Arts Movement/Black Art Aesthetic as "[F]eeling/contemporary and historical. Energy intensifies...the integral unity of culture, politics and art. Spiritual. Despises alienation in the European sense. Art consciously committed; art addressed primarily to Black and Third World people" (16). These ideas permeated the Black Arts Movement.

Artists continued to challenge the white hegemony. Nikki Giovanni poems spoke bluntly about black militancy writing in one of her poems "[c]an we learn to kill WHITE for BLACK" (Marable 104). Sonia Sanchez was known as the Black Power poet of Philadelphia (Painter 339). Also songs like Say It Loud, I'm Black and I'm Proud (1968) could be heard on the radio stations across America (337). Black Nationalist leader of the West Coast, Maulana Karenga created Kwanza, a Black holiday that included the "Swahili language and cultural imagery of Tanzanian traditional society" (Marable 105). He also created the organization $U s$ after the Watts riots to create some type of stabilization after it (Painter 325). He was interested in changing racist minds and detrimental patterns in the black culture (Marable 105). 
Ron Karenga also contributed his vision of the Black Aesthetic in his essay entitled Black Cultural Nationalism. He fought for the battle of the mind and felt that the black aesthetic was a critical tool in winning the minds of the Black people (Karenga 32). He acknowledged that there were two levels of art, social and artistic, but was more concerned with the social component of art (32). He states,

For all art must reflect and support the Black Revolution, and any art that does not discuss and contribute to the revolution is invalid, no matter how many lines and spaces are produced in proportion and symmetry and no matter how many sounds are boxed in or blown out and called music (33).

He agreed with the ideas Leopold Senghor ideas that art should be functional, collective and committed (33). Art is functional if it is useful for the community, or in Karenga's case, the revolution (33). It's collective if it is from the people, the artist recognizes their inclusion within a group, and it is returned back to the people (34). Art is committing if it commits to the revolution and change (37). According to Karenga "all our art must contribute to revolutionary change and if it does not it is invalid" (38). These types of nationalist sentiments were throughout the Black Arts Movement in art and theory. Those ideas paralleled with Myers optimal consciousness.

While Karenga was exploring the Black Aesthetic, Black scholar Addison Gayle, Jr. was fighting against the negative criticism from the dominate society. In Gayle's essay Cultural Strangulation: Black Literature And The White Aesthetic Gayle expresses the backlash that the Black aesthetic was receiving. Critics from The Saturday Review and the New York Review of Books discussed how Black Fire, edited by LeRoi Jones and Larry Neal "invoked the clichés of the social ideology of the "we shall overcome" years 
in their attempt to steer Blacks from "the path of literary fantasy and folly" (Gayle 39). White critics believed that there is "no Black aesthetic because there is no white aesthetic" (39). The false idea that all Americans are one dominated the critic's minds. Not only did whites criticize this new Black aesthetic, blacks did too! Black writer and scholar Ralph Ellison felt that sociology and art were incompatible mates when they were clearly linked together in the Black Arts Movement (39). Some of the criticism stated that "[t]o speak of a Black literature, a Black aesthetic, or a Black state, is to engage in racial chauvinism, separatist bias, and Black fantasy" (39). However Addison Gayle, Jr. provides documentation on how the white aesthetic has dominated literature within the society. Gayle mentions the Bible references of Black being inferior and white being superior as an example of the imperialistic nature of the white aesthetic (40). She states that Plato's two famous documents called The Symposium and The Republic, and how they differ from the Black ideas of aesthetics. The Republic discusses how the poet is an imitator of all that is beautiful versus a representation of society and an aid to assist the community (40). Gayle mentions, "[d]uring most of the history of the Western World, these aestheticians have been white; therefore, it is not surprising that, symbolically and literally, they have defined beauty in terms of whiteness" (41). She even mentions Shakespeare's plays Othello and The Tempest in reference to the characters Othello and Caliban, how their descriptions were always inferior to their white counterparts (42). She also mentions a book created in 1867 called Nojoque: A Question for a Continent that had chapters as blunt as "Black: A thing of Ugliness, Disease" and "White: A Thing of Life, Health, and Beauty" (43). In order to combat the ingrained racism and discrimination of a Black Aesthetic in our history she argues, 
The acceptance of the phrase "Black is Beautiful" is the first step in the destruction of the old tables of the laws and the construction of new ones, for the phrase flies in the face of the whole ethos of the white aesthetic... Black critics must dig beneath the phrase and unearth the treasure of beauty lying deep in the untoured regions of the Black experience--regions where others, due to historical conditioning and cultural deprivation, cannot go (46).

There was also an intellectual movement that was occurring as well, referring back to Africa for ideas on how to change the current situation of the black man. People were reading books by Frantz Fanon of Martinique, Julius Nyerere of Tanzania, Kwame Nkrumah of Ghana, and Amilcar Cabral of Guine-Bissau (Marable 105). Black students in universities began to fight administrations for black core courses. After students constantly expressed themselves through protest and even death, Black Studies programs were founded at San Franciso State University, Cornell, University of California Berkeley, Harvard, Princeton, and more (Painter 342).

At the same time Black women were becoming expressive about their own sentiments because they experienced both racism and sexism (338). Though Shirley Chisholm became the first Black women to be in the House of Representative in 1968, when she ran for president in 1972 she received little support from Black men because of the male chauvinism that existed (342). The book titled All the Women Are White, All the Blacks Are Men, But Some of Us are Brave: Black Women's Studies was published in 1982. Nonetheless organizations like The National Welfare Rights Organization and National Black Feminist Organization put Black women in roles to organize themselves (343). 
The Black Arts Movement was politically and socially conscious, actively rejecting the pressure to conform to just another commercialized unit. Singers like Nina Simone were singing about the black conditions while artist Dana Chandler's created a piece entitled Knowledge is Power: Stay in School (Karenga 472). The same thought provoking artistry that encouraged the Black spirit to rebel without restraint can be witnessed in the sounds of Arie, blunt edges of Walker, and the short-hand usage of Shange's play. When the ideas of Black Power were losing its ground in the 1970s due to government interference, the Black Arts Movement faded away as well.

\section{Hip-Hop, Culture, And Politics: The 1980s and Beyond}

After the Black Arts Movement, one of the main cultural explosions within the Black community was Hip-Hop emerging towards the end of the 1970s in the burroughs of New York like the Bronx and Brooklyn and going full throttle in the 1980s (Marable 225). It is commonly associated with rap music that has Jamaican origins, but the other elements of Hip-Hop are break dancing, graffiti and clothing (Painter 349). It has been described as an underground art form that "pulsated with the energy and aesthetic imagination of young African Americans who lived daily with police harassment, substandard education, poor housing, and unemployment" (Marable 227). Disc Jockeys (DJs) like Afrika Bambaata and Grandmaster Flash contributed to the break dancing competition and the scratching contest that built the Hip-Hop culture (Painter 364). Just like the Harlem Renaissance and the Black Arts Movement, the Hip-Hop Movement was expressed using art, music, literature, movies, and more.

Graffiti artist, Brett Cook, did a mural entitled Why Fight for a Crayon That's Not Our Color with text above it that said "[t]he worst part about us African-Americans 
isn't that we have to fight our ethnicity to be accepted by society. The worst part is that often [its] other black Americans that we fight with... Why are we so inclined to fight for a crayon that's not our color anyway" (349). In the mural two Black male figures fight over a white crayon. The artists from the 1980s and beyond, within the Hip-Hop culture, could voice their opinion directly on the walls in the inner city as Brett Cook did with graffiti. Cook made a comment on how Blacks lost their identity while trying to obtain the American dream, or the white dream (349). He wants the younger generation to remember their blackness which shows how the Black Arts Movement ideologies spilled over into the present.

In discussing this identity crisis that some Blacks were having post-Civil Rights scholar Painter acknowledges,

After the end of legalized segregation, the notion of authentic blackness became a preoccupation of the hip-hop generation. The need to define what constituted authentic--as opposed to inauthentic--blackness related to the increasingly visible diversity among people considering themselves African American ( 349).

This generation was all about defining themselves and critiquing those who were falling for the white dream disguised as the multicultural American dream.

During the 1980 s and beyond there was reclamation of Black History, the Black past that was not only in America, but Africa as well. These Blacks within this generation sought to celebrate the accomplishment of the Blacks in the past and heighten cultural nationalism as they continued to celebrate Black holidays like Kwanzaa (359). Blacks were studying African languages, wearing African clothing, and calling each other African American instead of Negro (359). A stamp was even introduced for Kwanzaa in 
1997 and Karenga wrote a book entitled Kwanzaa: A Celebration of Family, Community and Culture (359). Kwanzaa, a holiday once seen as a Black Nationalist holiday became an American holiday in which other cultures celebrated the teachings of those Afrocentric values ( 359). Afrocentrism is described as putting "black people at the center of historical narrative" (360). Afrocentrism was seen as controversial in the late 1980s and 1990s with the spread of Kwanzaa and books being published that defended the idea that Europe was greatly influenced by Egypt (360). The heightened interest in black culture was evident in academia, "By the mid-1990s there were some 380 academic AfricanAmerican studies programs and departments, at least 140 of which offered degrees" (361).

Black cultural tourism increased in the creation of Black museums that included The Martin Luther King, Jr., Center in Atlanta, Georgia, The Freedom Park/Kelly Ingram Park in Birmingham, Alabama, The Voters Rights Museum and Rosa Parks Museum in Montgomery! The struggle that the older generation was fighting for was finally manifesting, the dream of equal rights and Black progression seemed to be coming true (359). African Americans were also going back to West Africa to visit slave castles, places like Ghana and Senegal encouraged their travel (359).

In 1986 Martin Luther King, Jr.'s birthday became a federal holiday, marking monumental achievement in Black culture and history ( 359). There was also an open recognition to slavery that existed in the United States when the General Services Administration collaborated with the Schomburg Center of the New York Public Library and Howard University to "re-bury the remains of four hundred enslaved people in the African Burial Ground" (360). On top of the new burial ground was a sculptor called 
"Africa Rising" by Barbara Chase-Riboud that includes an abstract depiction of a slave ship, enslaved Africans, and Sarrtje Baartmann ( 360). This art was a functional piece for the new burial ground, a symbol of liberation finally.

Blacks were also noticed for their achievements. There was Tiger Woods, one of the first prominent Black golfers, Venus and Serena Williams, two Black remarkable women tennis players, Michael Jordon, a basketball hero, Michael Jackson, an iconic internationally known singer, Oprah Winfrey, famous television host, Denzel Washington and Halle Berry, first Blacks to win Oscars for best actor and actress, political activist Jesse Jackson runs for president, Toni Morrison winner of the Nobel Prize for Literature and the list goes on and on (361). There is an immense amount of racial pride for the African American community occurring. At the same time there were still ancient issues like skin-color within the black community. The image of beauty for a female was young, white, or light-skinned ( 363). Hence India. Arie sings, "I'm not the average girl in the video..." later became a counter narrative to this idea.

Hip Hop was still thriving, artists like N.W.A. (Niggaz with Attitude), Run DMC, and Ice Cube all made records that discussed the issues Blacks were experiencing in their community from the drug abuse to the police brutality (363). Graffiti art was seen everywhere from subway cars to inner city walls, it was the art of the street (363). There was also the entrance of the first female rappers that were highly successful like Salt ' $N$ ' Pepa (366). Movies were even a part of the Hip-Hop Culture. Some of the movies were New Jack City, Boyz N the Hood, Straight Outta Compton, and Menace II Society (366). In describing Hip-Hop, Painter states that "Rap music defies easy characterization, for its messages are varied and even conflicting" (366). Though there was rap music that 
discussed racial pride, Black history, and moral conduct, the inclusion of police brutality and graphic sex in the lyrics of the rap music made it controversial (365). Rap music was defined as numerous things " political, critical, culturally astute, hedonistic, social realist, degrading to women, homophobic, homoerotic, moralizing, feminist, materialistic, violent, black nationalist, entertaining, pornographic, and just plain funsometimes all at the same time" (367). There was even the inclusion of Lauryn Hill who is seen as a Neo-Soul and Hip-Hop artist; she won five Grammy Awards ( 367).

Literature in the 1980s and 1990s was changing as well. Black women authors dominated this period (Karenga 490). There was Alice Walker's The Color Purple, Toni Morrison's Beloved, Rita Dove's The Yellow House on the Corner, Pearl Cleage's What Looks Like Crazy On An Ordinary Day, and Gwendolyn Brook's books of poetry ( 491). There was also controversy over the negative depiction of men in Black books, yet men continued to write as well (491). There was August Wilson's plays Fences and The Piano Lesson, Henry Duma's Goodbye Sweetwater, Henry Louis Gates and Nellie Mckay, Norton Anthology of African American Literature, and more

(492). There was even an increase in literature criticism with Mari Evans' Black Women Writers: A Critical Introduction, Barbara Christian's Black Feminist Criticism: Perspectives on Black Women Writes, Fred Lee Hord's Reconstructing Memory: Black Literary Criticism (493). Another tendency of Black literature of this time period was its deviation from social engagement that was prominent in the Black Arts Movement. As Karenga states "there is a tendency for the authors to distance themselves from the long literary tradition of social engagement" (493). 
In describing contemporary art, one of the artists of this study Kara Walker serves as an example of the new attitudes of the visual artist of the 1980s and beyond. Walker deliberately plays with racist stereotypes in her silhouettes, it is stated that "[h]er pornographic imagery not only protests against but plays with racist myths of the black girl as a receptacle for white male fantasy and source of physical labor" (Bernier 193). She is a part of the contemporary African American artist that "rely similarly on satire, irony, caricatures and bathos" (193). However unlike the older generation who wanted to celebrate the freedom fighters, Walker is "a part of a new generation of artists which may not feel as compelled to dignify, aggrandize and monumentalize black culture as those of an earlier era but who are still determined to signify upon theories of 'history, truth, reality, and conscious subjectivity' (196). Walker produces contemporary artwork that is confrontational, uncensored, and critiques the older African American art tradition (209). Art in the 1980s and beyond introduced a lot of rebellious artist as Kara Walker wanted to "fight for aesthetic freedom in the face of black censorship" (210). Though she is discussed as representing the youngest generation of artist, she is still included with her predecessors David Hammons, and Howardena Pindell that "relish in being the 'bad guy' by refusing to serve up sanitized and acceptable representations of black bodies, cultures and lives" (220). It is the freedom to do and say what they want without consideration of what people think, which is endorsed in Kara Walker's statement to one of her nemesis, artist Betye Saar, "[y]ou look or you don't look. But I'll make it as long as I have to. The whole gamut of black people, whether by black people or not, are free rein in my mind" $(220)$. 
While artistically things were changing, there was also a shift politically as well. Whereas in previous years there were collaborative efforts to move the black community as a whole as seen in the Harlem Renaissance and the Black Arts Movement, in the 1980s and beyond there was an emphasis on the black individual (Painter 350). Policies like Affirmative Action that began in the ' 60 s were created to increase minorities in jobs and schools made it easier for African Americans to get a slice of the American pie. The piece of the American pie also included individuality and separation from the Black unit.

Affirmative Action is described as "various governmental and non-governmental policies aimed increasing the numbers of blacks, Latinos, Native Americans, and white women in institutions that have previously discouraged their presence" (350). The policy was introduced in the 1960s by John F. Kennedy, and due to these policies more minorities were able to get better jobs that were limited to white men and go to colleges (350). The ideas of affirmative action were to "compensate for past discrimination" $(350)$.

Though many African Americans supported it because they thought it encouraged "access to jobs and higher education and discourages racial discrimination," there were opposing opinions (351). Some believed that affirmative action was 'reverse discrimination' and allowed white colleagues to lose credibility for blacks in good jobs or higher institutions with the idea that it was only because of affirmative action and not good work ethic or scholarly achievement (352). With the 1980s also came the Reagan administration that was against the ideas of affirmative action, and though some blacks felt like it was an attack on the Civil Rights Movement, other Blacks looked at it as a "prospect of being respected as individuals, not stereotype[d] as members of a race" 
(352).

However Black Democrats were also very influential politically. Bill Clinton who came into office in 1993 was named the 'first black president' before Obama due to his popularity within the black community (354). 82 percent of the African American electorate voted for him (Marable 218). Also in the south, urban north, and west most of the black representatives elected were Democrats (Painter 354). Though he was heavily supported by black voters, black candidates for his administrations were denied positions and he was slow to react to the war in Rwanda (Marable 218).

In the 1990s the idea of reparations became more accepted due to the fact that Blacks were still in poverty, receiving poor healthcare, jobs, and housing (Painter 358). There was also a series of wars that occurred, the Gulf War of 1991 and the War of Iraq of 2003 (368). Unlike the war efforts previously, like the one in Vietnam, there was more of a visibility of black officers (368). At the same time, there were still Blacks who were against the war efforts (368).

Numerous racist acts also occurred in the '90s. James Byrd, a disabled middleaged black man was killed by three white men who "tied him to the rear of a truck, and dragged him to death on a rural road" (Marable 219). Also there were over 100 firebombings of Black churches in reminiscence of the 1963 church firebombing in Birmingham during the Civil Rights Movement (219). Research also showed that Blacks were getting higher interest rates when it came to home loans and were the first to be fired at major companies like Coca-Cola during the recession of 1990-1991 (221). Police brutality continued to surface with the emergence of the Rodney King Case, a Black man beaten relentlessly by white policemen of the Los Angeles police force (223). Abner 
Louima, a Haitian immigrant was terrorized after he was arrested and taken to a police station where he was "forced into a toilet, and police rammed a wooden stick from a plunger up his rectum" (224). Also Amadou Diallo, a Guinean immigrant was wrongfully shot 41 times (224). It did not matter your country of origin, if you had black skin, you experienced some sort of racism.

In 1994 there was the "Million Man March" in Washington, D.C that encouraged "spiritual atonement, greater personal responsibility and group solidarity among African American males" in spite of the public racism occurring (228). Three years later there was the "Million Woman March" in Philadelphia's Benjamin Franklin Park that promoted the" development and completion of independent schools" and a rites of passage center for Blacks "to ensure qualitative growth and development in black males and females approaching adulthood" (229). There was even the "Million Youth March" in 1998 (229).

Towards the end of the 1990s, the Clinton administration began to apologize for racial incidences that occurred in the United States. In May of 1997 Clinton apologized for the Tuskegee syphilis experiment that infected a hundred black men with syphilis starting in 1932 (234). In 1998 he expressed regret for "America's involvement in the trans-Atlantic slave trade" (234).

While there was a push for reparations due to slavery, there was also the "demands by African nations for debt forgiveness" (238). In 1999 there was the creation of the "African World Reparations and Repatriation Truth Commission" that filed "claims for restitution against international corporations, banks, and international agencies" (239). The United Nations, from 2000-2001 created a series of conferences that 
discussed racism and socioeconomic problems globally (239). There was also a "HipHop Summit” thrust forward by Hip-Hop Mogul Russel Simmons (240). For the first time you have the interaction with public policy makers and scholars like NAACP president Kweisi Mfume, Cornel West, Michael Eric Dyson, Manning Marable, Tricia Rose talking to Afrika Bambaataa, Kool Herc, Grandmaster Flash and the youth to promote voter education and registration while supporting social justice activities (240). Hip-Hop, specifically rap music served the radical component of the Hip-Hop Movement and it was derived from the West Indies via Jamaica just like Marcus Garvey during The Harlem Renaissance and Malcom X during the Black Power and Black Arts Movements.

The beginning of a new millennium came with new challenges. In September 11, 2001, Al Qaeda hijacked two planes and "struck and destroyed the World Trade Center in lower Manhanttan, and a third airplane crashed and destroyed a section of the Pentagon" (241). This act launched much turmoil in the United States and anything associated with Islam was under heavy scrutiny. Though African Americans were upset with the attack, they were also disturbed by the "national chauvinism and numerous acts of violence and harassment targeting individual Muslims and Arab Americans" (241).

In 2003 the War on Iraq began and African Americans according to poll opinions were the least in favor of it (242). The Congressional Black Caucus and the NAACP felt the war on Iraq was a "misuse of funds that were needed in black communities and poor neighborhoods" (Painter 368). At the same time in the past, it was Black groups like the NAACP that supported blacks involvements in the war in Vietnam in the 1960s and 1970s. Yet strives were still being made to honor the African American culture with the creation of the National Museum of African-American History and Culture in 2003 that 
was originally requested in 1915 by black Civil War Veterans (360). That museum was to be a part of the Smithsonian Institution (360).

A couple years later in 2005, Hurricane Katrina came and destroyed areas in Louisiana, Mississippi, and southwestern Alabama (Marable 250). New Orleans was hit the worst, and many African Americans of lower socio-economic standards suffered (251). While some people were able to evacuate from New Orleans, "residents who would be trapped inside the city to face the deluge would be poor and working class African Americans, who compromised nearly 70 percent of the city's population" (253). Ntozake Shange joined a host of other poets in reading their poetry to raise money for Hurricane victims in Mississippi (Bullock). Kara Walker did a whole visual graphic book dedicated to Hurricane Katrina called After the Deluge. India. Arie allowed her song called What About the Child available online for a $\$ 1$ in which proceeds were donated to children affected in Hurricane Katrina and Rita (lyricsfreak).

Through this brief journey, there were examples of how art has always been functional in the Black experience. The Harlem Renaissance artists encouraged Black art and its deviation from the status quo. The Black Arts Movement took it even further, using art as a weapon to create social change after the continuous racist attacks by the American society. While the Hip Hop Movement provided us with new artistic platforms to express social issues ranging from politics to education using graffiti and rap. Black art has and will always serve as a tool for change allowing Ntozake Shange, Kara Walker, and India. Arie to join an artistic legacy. 


\section{CHAPTER V \\ WHO ARE THEY?}

\section{Ntozake Shange}

The orisha Oya, a deity of the Yoruba in West Africa known for her "disastrous consequences", can be applied to many modern day performance artists especially artists like Ntozake Shange. "Oya speaks her mind," author Judith Gleason affirms in her book Oya: In Praise of an African Goddess. Gleason depicts Oya as wind, fire, and other manifestations (Gleason 1). In the aforementioned novel the turbulent encounters that occur when Oya is around create rivers like the River Niger (5). This weather goddess is quick tempered, and is known for her "transformation from one state of being to another" (2). She shows a side of femininity that is powerful and unapologetic. Orishas are archetypes of personalities, which is why some elements of Ntozake Shange can parallel with Oya. As stated in the chapter I Introduction, Oya has many manifestations such as wind, fire, the buffalo, and the River Niger (Gleason 2). Shange can dance like the wind and her words in her performances and books can create a fluid effect like the wind, which can be calm or chaotic. She also has many manifestations as a dancer, playwright, and scholar. She is hot like fire and can create a burning sensation in her audience, but can be cool as the River Niger; Shange's embodiment of Oya qualities is evident. These characteristics of Oya shows how traditional African influences are representative in the 
modern day Black culture in the United States. Even Ntozake Shange names has reference to cultural to ties to Africa being a Zulu name. Ntozake Shange embodies Oya's qualities. Shange maintains a fiery temperament that can create change. Her words are infused with feminine empowerment as well as chaos through her unorthodox use of the English language. Ntozake Shange's name means "she who comes with her own things" and "she who walks like a lion" (Anderlini 85). She personifies a female warrior and is unapologetic about her strength and femininity.

Her father Paul T. Williams was a surgeon and her mother Eloise Owens Williams was a psychiatric social worker and educator Her home was frequented with intellectuals like W.E.B. Du Bois and famous jazz musicians such as Miles Davis and other entertainers and prominent people such as Paul Robeson, Josephine Baker, and Cesar Chavez all of whom influenced her as an artist (Burke 183 ; Beauliu 786-787). Shange grew up learning about Paul Laurence Dunbar, Langston Hughes, Shakespeare and T.S. Elliot (Thompson 656). She also read Zora Neale Hurston who she considers to be her "literary foremother." This demonstrates how Black artists from the past impacted her works (Fisher 84). Zora Neale Hurston and Shange share a similarity in their usage of the English language which will be seen later.

In discussing her childhood, Shange remembers the family's Sunday afternoon variety show when her father would play the congas, while her mother read Shakespeare and the children sang and danced (Thompson 656). When she was a child she moved to St. Louis where she first experienced racism by the white children (Gavin 193). She felt alienated not only from school mates at the predominately white school, but from her parents who wanted the world to know that they were Black, rich, and proud (193). 
Though she was getting a cultural experience at home, she felt that she did not really have any artistic role models as a Black girl in school (Thompson 656). As she grew older and made it through school, she summed up her experience, "I had finished school, Black arts had taken on an incredible anti-female aura. All the men I knew were running around getting ready to die...I couldn't possibly sit up in nobody's kitchen forever baking nothing" (Gavin 193). In that one quote she has indirectly mentioned the Black Power and Black Arts Movements, Vietnam War, Black on Black crime, and the sexism experienced by Black women. At the age of 19 , she even tried to commit suicide due to a failed relationship. She attempted suicide a couple more times later due to challenges in her life (Thompson 656; Gavin 193). In 1971, after doing some soul searching, Shange realized her animosity towards her middle class upbringing. She also grew to appreciate the influences of the Black Power and Women's Liberation Movement. These forces and revolutions encouraged her to change her name to Ntozake Shange. She stated, "I had a violent, violent resentment of carrying a slave name; poems and music come from the pit of myself and the pit of myself wasn't a slave" (Gavin 194). After graduating from Barnard College in 1970 she received her Master's Degree in American Studies from the University of Southern California in 1973 (194). She intended to get her doctorate but once she realized how few Black women had Ph.Ds she felt that she would be even more isolated and decided not to pursue it (194). While in graduate school Shange worked as a war correspondent and jazz musician, while writing poems and choreographing dances (Beauliu 787). Upon receiving her degree she taught classes in African/African American Studies, Humanities and Women Studies at Mills College in Oakland, the University of California Extension in San Francisco, and Sonoma State 
College (Burke 183; Thompson 657). While teaching at Sonoma her work with artists like poets and dancers and teachers allowed her to further develop her knowledge about oppressive experiences of women (Thompson 657). There she was able to cultivate her ideas over a three-year span on womanhood working with courses such as Woman as Artist, Woman as Poet, Androgynous Myths in Literature, Women's Biography I \& II, and Third World Women Writers (Shange $\mathrm{x}$ ). The knowledge she gained from these courses contributed to her For Colored Girls Who Have Considered Suicide When The Rainbow Is Enuf, especially the piece called Sechita about a dance hall girl embodying a deity, slut, innocence and knowing ( $\mathrm{x}$ ). Shange was also a part of several dance companies such as the Third World Collective, Raymond Sawyer's Afro-American Dance Company, and the West Coast Dance Company where she performed poetry and movement that later would influence For Colored Girls Who Considered Suicide When The Rainbow Is Enuf(Fisher 84). In describing what dance did for her, she mentions, Knowing a woman's mind \& spirit had been allowed me, with dance I discovered my body more intimately than I had imagined possible. With the acceptance of my ethnicity of my thighs \& backside, came a clearer understanding of my voice as a woman $\&$ as a poet. The freedom to move in space, to demand of my own sweat a perfection that could continually be approached, though never known, waz poem to me, my body \& mind ellipsing, probably for the first time in my life (Shange xi).

Within this quote she mentioned the fusion of the sacred and secular through the spirituality she experienced while dancing. She also discussed the interpersonal relationship she had with herself, with her words, movement, and with mind and 
body.Shange's experience with the Halifu Osumare's The Spirit of Dance Troupe allowed her to explore herself more intimately, after dancing with them she began production of For Colored Girls Who Considered Suicide When The Rainbow Was Enuf (xii).

Ntozake Shange was highly aware of her position, of being a Black woman who experienced double prejudice, sexism and racism. Much of her work was influenced by the issue on women's rights yet she was honest and aware of the racism within the various strains of the women's movement. As stated by Delores P. Aldridge on the proximity between the Women's Liberation Movement and the Civil Rights Movement, "[t]he Women's Liberation movement following on the heels of the civil rights movement served as a catalyst for conscious-raising on women's issues" (Aldridge 157). Organizations like the National Organization for Women (NOW) were created to combat women's issues, and were modeled after the NAACP (415). On the other hand, the Women's Liberation Movement was predominantly white middle class women as stated "[a]lthough black women in civil rights inspired women's liberation in many ways, and although women liberationists were committed to fighting racism, nevertheless women's liberation was overwhelmingly white" (417). In discussing the lack of inclusion of the Black woman in these two critical movements, Aldridge mentions "neither has been particularly sensitive to the unique experience of women of African descent in America, on the continent or through the Diaspora" (Aldridge 158). Within the Civil Rights Movement existed a fair amount of sexism that Black women had to experience, African male activists publicly acknowledge expectations that women involved in the movement conform to a subservient role pattern. This sexist expectation was 
expressed as women were admonished to manage household needs and breed warriors for the revolution (159).

This male chauvinism that existed which suppressed the Black women's experience can be best described by writer Toni Cade Bombara, "[i]nvariably, I hear from some dude that Black women must be supportive and patient so that black men can regain their manhood" (159). The exclusion and indifference African American women experienced in these movements presented itself in Shange's work as a platform were their issues could be expressed openly. She used theatre to make a political statement and create a space for Black women voices.

Therefore her play For Colored Girls Who Have Considered Suicide/When the Rainbow Is Enuf which was influenced by these movements occurring almost simultaneously provided a connection point for being Black and being a woman. Ntozake Shange cleverly created a play about women, casting only women, and discussed minority women's issues. One critic describes the work of Ntozake Shange in the following, "In all her works, Shange suggests that black women should rely on themselves, and not on black men, for completeness and wholeness. She speaks for women of every race who see themselves as disinherited and dispossessed" (Thompson 657).

When creating the pieces, Shange worked at the Bacchanal, Ed Mock's Dance Studio, with assistance from the West Coast Dance Works during the summer of 1974 (Shange xii). She worked intimately with Paula Moss who assisted in her choreopoetry (xii). They began touring For Colored Girls Who Have Considered Suicide/When the Rainbow Is Enuf in Women's Studies Departments, bars, cafes, and poetry centers (xiii). 
The play was brought to the stages in 1974 (Thompson 656). She wanted to keep the performance organic which attests to her authenticity, and avoided institutions as a poet that she thought included producers, theaters, actresses, and sets (Shange xiv). Shange did not want to treat it as simply a commodity for entertainment; her performance had message for the spirit that she wanted to protect especially since it was her own creation. As the show gained in popularity, Shange resigned as director because she "acknowledged that the poems \& the dance worked on their own to do \& be what they were" (xiv). She gave the piece her authentic air and now it could breathe without her. She finally decided to take the show to those places that she originally avoided. Woodie King, Jr. produced the show for a workshop under Equity's showcase code at the Henry Street Playhouse. The play eventually made it to the Booth Theatre on Broadway in 1976 (xv).

It was a very influential and popular play running on Broadway 747 times and in 1977 it won an Obie Award (Gavin 193-194). Ntozake Shange was the second African American woman to have her play debut on Broadway after Lorraine Hansberry's $A$ Raisin In The Sun (Burke 184). For Colored Girls Who have Considered Suicide When The Rainbow is Enuf also won an Outer Critics Circle Award, Audience Development Committee (Audelco) Award, and a Mademoiselle Award, while the performance was also nominated for a Tony, Emmy, and Grammy Award (Beaulieu 787). She won another Obie in 1981 for her adaptation of Brecht's Mother Courage and Her Children.

Though she received great honor, she also gained criticism. The males discussed in her play were said to be one-dimensional and the females full-bodied individuals (Gavin 194). Her response was the following, "I was totally startled by the 
vociferousness of their response...I was coming out of this incredibly feminist environment in Oakland and then New York, and all of a sudden all these men were all upset. And I thought, this play had nothing to do with them! This was all about women!" (194).

In describing her work, "Shange's aesthetic is grounded in the affirmation that art is a tool. Art must do something other than act pretty" (194). Shange took a stance on the importance of being a minority woman and the lack of expression that existed to illustrate the experience:

What I'm getting at... is the ability to be in your woman's body....

A lot of black and Latin women have not been allowed to be inside themselves, to really feel what that's about. Cause we've been so busy being revolutionaries or being reactionaries, or being 'ladies' that we forgot about it (194).

Though For Colored Girls Who Considered Suicide When The Rainbow Is Enuf has been considered a play primarily for Black women she "touches upon problems such as rape, abortion, physical and emotional abuse, and infidelity, women across all cultures, ethnicities, and economic strata can relate to Shange's art and message" (195).

When it comes to her view on herself as an artist, she would rather not be called a playwright but a poet because she is "interested solely in the poetry of a moment/ the emotional \& aesthetic impact of a character or a line" (195). In describing her tools, "[n]onstandard spellings and punctuation make her language dance. Her words have been described as "unorthodox capitalization, punctuation and spelling, and the use of African American idioms, dialect, slang, and rhythms" (Thompson 657). Yet these dancing words are also creating a form or resistance to standard English that teaches "colored girls" to 
hate themselves (Beaulieu 789). She does not care for the European theatre using words like shallow, stilted, and imitative to describe it and stated, "for to long now afroamerican[s] in theatre have been duped by the same artificial aesthetics that plagued our white counterparts/ "the perfect play" as we know it to be/a truly european framework for a european psychology/cannot function efficiently for those of us from this hemisphere" (Gavin 195).

Her plays include spoken word, dance, music, and more unusual conventions that are seen in her choreopoem For Colored Girls Who Consider Suicide When the Rainbow Is Enuf. She is believed to have developed the choreopoem "an eclectic form of theatre, to protest the traditional linear dramatic form, symbolic of the Western patriarchy system" (195). It is also defined as an "art form that synthesized poetry with drama, dance, and music" (Beaulieu 787). Dance and music are just as influential in Shange's pieces "as they are to her spirit" (Gavin 195).

Later Shange did accept the term playwright, but with feminist sentiments of course. In her 1989 interview with the New York Times, “I'm a playwright. But I am a woman first. I am not a generic playwright. I am a woman playwright. And I would hope that my choice of words and my choice of characters and situation reflect my experience as a woman on the planet" (Burke 184).

Her work has been compared to that of Audre Lorde and Toni Morrison because it "creates discourse on the black female body that defies ideals and stereotypes of beauty repressing black women's looks and intelligence" (Beaulieu 788). She has been described by critics like Mary Deshazer as not only writer but a warrior while discussing how her work is fueled with Frantz Fanon's combat breath (Thompson 657). Ntozake Shange is a 
positive icon because she provides a healing space for women of color and positions herself within an Afrocentric perspective. Critics have stated that "Ntozake [represents] black women without compromising their integrity" (Gavin 193). Dona Richards expresses the importance of icons, because through them a culture can be inspired or degraded. Shange's work provides icons that are functional to the society and is an acknowledgement of, "[w]omen's creativity and wisdom are rendered into a radical language and style, creating linguistics spaces of resistance and empowerment for women of color. Recovery of female power and sensibility is not just play; it is a serious undertaking to redefine female subjectivity or identity in a sexist, racist culture" (Beaulieu 788)".

Kara Walker

Kara Walker is another artist that can be viewed through the context of African mythology and archetypes. Walker represents a female version of the trickster described in Pelton's The Trickster in West Africa. She stands in between the heavens on the earth with a pair of scissors and black paper. Just as a traditional trickster goes back and forth to heaven and earth "both as social enterprise and as divine gift," Walker treads the same road (Pelton 4). In describing the trickster, Pelton affirms: "Loutish, Lustful, puffed up with boasts and lies, ravenous for foolery and food, yet managing always to draw order from ordure..." (1). A viewer may see a silhouette by Walker and initially think chaos, but then notice the method to the madness.

Some of the common West African tricksters are Ananse of the Ashanti, Legba of the Fon, Eshu of the Yoruba, and Ogo-Yurugu of the Dogon (5). Walker, like these infamous tricksters, is "complex and intellectually provocative" (5). Kara Walker 
represents a younger generation of African American artists that builds on the foundation of Ntozake Shange's lethal art.

Kara Walker's art maintains a revolutionary spirit, she stated on one of her index cards from an exhibit, "I make art for anyone whose forgot what it feels like to put up a fight..." (McEvilley 53). Kara Walker's art is considered to be explicit, raw, and controversial. She has been thought to make "the white written text speak with black voice..." (Shaw 5). She uses literature and images of the antebellum South to impact her silhouettes. When describing her art, Kara Walker states, "The audience has to deal with their own prejudices or desires when they look at these images. So if anything, my work attempts to take those "pickaninny" images and put them up there and eradicate them" (103).

Born in 1969 in Stockton, California, her father was also an artist who taught painting at the University of the Pacific (Dixon 12). When she was a pre-teen, her father took a new professorship at Georgia State University in Stone Mountain, Georgia where the terrorist group the Ku Klux Klan was founded (12). Kara Walker had a hard time fitting into the new environment. The Black students felt she sounded like a white person because of her California background and the white students shunned her because of the color of her skin (12). Though isolated from her peers, it did not stop her from pursing her passion for art to which she had easy access because of her father.

When she attended the Atlanta College of Art, she purposefully resisted racial themes in the beginning because her professors assumed or thought that she would employ them. They were wrong because "she is not the type of woman that bows to the expectations of others" (13). However when she went to graduate school at the Rhode 
Island School of Design she began to embrace those racial themes that included black womanhood, American Chattel Slavery, interracial romance, and the fictions of the South (13). She began exploring ways in which she could interpret this period of the Antebellum South about which she was so fascinated by creating silhouettes made out of black paper. She also read authors like bell hooks, Michelle Wallace, and browsed through pornographic novels, for more inspiration and understanding of what she was trying to create.

Similar to an enslaved person, it was not until she left Georgia for Rhode Island that she could release the chains of artistic oppression and be free to explore themes that were both racial and sexual by creating the silhouettes. Walker attests that "In a way making silhouettes kind of saved me. Simplified the frenzy I was working myself into. Created the outward appearance of calm" (13). She uses the silhouette art form knowing that "it has historically been a weaker, more feminine form, one that might have been accessible to the nineteenth-century African American women artists" (20).

Walker also created a character to further embody her work. She created the persona of the Negress, placing her body, mind, and spirit into her art. When she was creating this alter ego she clarifies that she "was thinking along the lines of some of artist Adrian Piper's ${ }^{i}$ early performances, where she invented an identity for herself through her 'Mythic Being' in public arenas" (12). She looked at herself as the master of ceremony in her show that included the pickaninny, mammy, nigger wench, sambo, master, missus, uncle tom, and more racialized characters of the time period,

For me they become characters the moment I start working with them. Because they become mine in a way. So that when I encounter the much-contested African 
American tchotchkes ${ }^{\mathrm{ii}}$ and derogatory images, they don't have the power over me that they used to...Being an artist in control of characters that represent the social manipulations that blacks have under gone in this country at least, puts me in the position of being the controller or the puppet master of imaginary black people (18).

One character that she chooses to frequent her pieces is the "nigger wench." She found the characteristics of this subject from a pornographic novel called The Master's Revenge and she is described as a "young and pretty black girl whose function is as receptacle--she's a black hole, a space defined by things sucked into her, a 'nigger cunt'." A sent, an ass, a complication...She is simultaneously sub-human and super-human" (19). She exhibits an alternative role of the Black woman as not only to be seen as an animal, but a person who possess super powers. She uses the characters like the nigger wench in roles that allude to and defy the derogatory position placed on Blacks as seen in the pornographic novel for example.

Her silhouette installations are likened to an "epic scale of history painting, [with] the caustic bit of political satire, and the scopophilic draw of pornography" (13). Though she had been exploring these unconventional ideas during her early career, it was not until 1994 at the tender age of 25 that she gained recognition with her silhouette wall installation titled Gone: An Historical Romance of a Civil War as It Occurred Between the Dusky Thighs of One Young Negress and Her Heart at the Drawing Center in New York City (14). Soon after her exhibits of black silhouettes exploring racial and sexual themes of the Antebellum South, her work began to be seen around the world. Her art graced Paris, France; London, England; Sydney, Australia; Vienna, Austria, and was 
chosen to represent the United States as a sort of artistic ambassador at the Sixth International Istanbul Biennial in 1999 (16-17). She even created the opera safety curtain for Vienna, Austria during the 1998-1999 season (17). At times her silhouettes were accompanied by text that she had written such as Freedom: $A$ Fable a pop-up book that she created in 1997 (15). At the turn of the millennium, Walker was a successful young Black artist who used racial propaganda from the Antebellum South as her muse for creativity. This use proved profitable for her wall installations sold for well over six figures (17).

Gwendolyn Dubois Shaw, who wrote on Walker, stated that she "is an artist with the uncanny ability to make her audiences see the unspeakable" (9). She also believes that the reason that she has been criticized so much is because of the "broader culture's inability to come to terms with the past" (6). In the critic Sander L. Gilman's essay, Confessions of an Academic Pornographer, she explores the conversations in the art world about Walker's work being associated with pornography because of the racy cutout pictorials which Walker calls narratives. Kara Walker has been ridiculed for her art, and her achievements have been met with criticism from other Black artists who felt that she did not deserve the recognition she received. For example, in 1997 she received the sought-after MacArthur Foundation "genius" fellowship, but other African American artists, such as Betye Saar were appalled that she received the honor. Walker's work was charged with "making dirty pictures, or making pictures that pandered to racism" and also Saar believes that her work was "sexist and derogatory"(Sander 29). Walker was the youngest woman to receive the award and many established artists of the older generation did not appreciate her work getting recognized before theirs, they "felt that she had not 
paid her dues and that she did not realize the full impact of her work" (114). Her prime nemesis Betye Saar initiated a massive "letter writing campaign" to boycott the work of the young Kara Walker stating that "I have nothing against Kara except that I think she is young and foolish" (115). Saar felt that Kara Walker's work was "catering to the bestial fantasies about blacks created by white supremacy and racism" (McEvilley 53). She was even considered to be a surrogate to express the racist feelings of white people (53). That same year an older African American male artist whose work was less controversial received the MacArthur award and received no harsh feedback like Kara Walker experienced (114).

On the other hand, Henry Louis Gates believed that Walker's art was a "profound act of artistic exorcism" (McEvilley 56). Also the younger generation of Black artists were not as offended of her usage of irony, bestiality, miscegenation, ambiguity, sarcasm, eroticism, and more (56). Kara Walker explores the good, bad, and ugly vividly, causing people to see a side of history and mental interpretation that others choose to hide.

Betye Saar, an older African American artist, created The Liberation of Aunt Jemima in 1972 to empower the Black mammy stereotypes (Sanders 29). Some people did not understand how Saar could comment on Kara Walker when she too used stereotypical black images in her artwork too, her Aunt Jemima piece was created in the racially charged time period of the 1970s (116). Walker was also seen as a "sell out" for taunting black stereotypes, especially enslaved Africans in the faces of white men. These criticisms never made Walker put her scissors down. She kept cutting and in 1999 her exhibit in the Detroit Institute of Arts (DIA) was removed because of the complaints of the Friends of African and African American Art (Sanders 29). 
The effects of efforts to censor Walker continued. Her five panels called $A$ Means to an End: $A$ Shadow Drama in Five Acts were supposed to be included in the DIA exhibition titled Where the Girls Are: Prints By Women from the DIA's Collection (Shaw 103). The Friends of African and African American Art believed that it was "not an appropriate time for the display of the work... primarily because it's controversial and there's no clear art--historical position with respect to [Walker's] work" (105). Author Gwendolyn Dubois Shaw believes that the primary reason her work was removed from the DIA art exhibit was because there was not a qualified art historian or "culturally and critically sensitive curator" who could properly present her work to the public (112). Recently DIA has hired a curator who has the qualifications to explain and present the work of such controversial Black artists like Kara Walker (113). The DIA is an example of many museums that want to explore Black artist's work but lack a qualified curator to explore thoroughly the work of Black artist which prevents Black art from being seen (113).

Walker's constant repetition of the foulness of slavery with images of miscegenation, rape, death, and ambiguity makes some Blacks uneasy. These idiosyncrasies have been called out in publications like The International Review of African American Arts in which she responds to the hatred and unfair observation of her art in the following words, "It was quite embarrassing and strangely obtuse that two issues of a magazine supposedly devoted to unraveling the lure of stereotypical, racist imagery should rely so heavily on stereotypical racist imagery of the kind that blacks dole out among themselves" (Sanders 30). 
She has been likened to the younger generation of artist in the Harlem Renaissance like Langston Hughes and Zora Neale Hurston who choose to depict art that was not always seen favorably to the Black middle class (Shaw 115). One example of Hurston's controversy occurred during the Harlem Renaissance when author Richard Wright stated this about Hurston's Their Eyes Were Watching God, Miss Hurston voluntarily continues in her novel the tradition which was forced upon the Negro in the theatre, that is, the minstrel technique that makes the white folks laugh. Her characters eat and laugh and cry and work and kill; they swing like a pendulum eternally in that safe and narrow orbit which America likes to see the Negro live: between laughter and tears (116).

Walker experienced conflict just like her predecessor Robert Colescott whose painting Natural Rhythm: Thank You Jan Van Eyck was pulled from the University of Missouri-St. Louis in 1993 because of its depictions of a Black stereotypical image of a woman with pink lips (108). It was the Black students and administration that found his painting hung in a common area displeasing (108). In response to the actions he states, "...what happens is this: some African Americans see my painting and get upset. Then the curators get nervous...So if a black person complains, we must take it down because we are good liberals. But it's still censorship" (109). The work was created in the 1970s to not only explore the lack of the African or African American presence in early Western Art but to also "maintain a certain racial tension in the 1970s art world" (108). The work he made during that time period was "ironic and allegorical, satirical and sociological" (109). In 2004, Walker finally was able to show her work at a museum dedicated to African American culture, the Studio Museum in Harlem (123). 
Walker's work has been stated to have used primitive elements in exploring both the white and Black sentiments. In Thomas McEvilley essay, Primitivism in the Works of an Emancipated Negress, he explores how Kara Walker's work uses primitivism. In describing this he states,

A primitive culture, whether referring to pre-civilized or non-civilized societies, is viewed as being a lower degree of advancement than a civilized one. One's placement in the hierarchy is determined by who is making the judgment, and history provides numerous examples of two cultures meeting and each regarding the other as primitive relative to itself (54).

In Kara Walker's silhouette narratives both the Black and white people are culprits of violent acts towards each other. A viewer may have a hard time trying to figure out who is right and who is wrong, but this idea of showing both races as capable of inhumane acts provides more truth than what has been displayed in the American fabric. Africa has long been assumed to be a continent of darkness, stupidity, and ignorance. Africans in the Diaspora have been cut-out to be one-dimensional characters civilized only by the help of the white man. Under the European influence “...virtually the entire nonwhite world was included in the [primitive] category. Most societies deemed primitive in the colonial era had accepted a non-progressive, Neolithic, village style-culture led by a tribal "big man"; such societies had no definition of history and operated without an inner mandate of change" (55).

Through Walker's Black caricatures, there is a sense of primitivism, however she inverts the idea and shows white people doing acts of violence, rape, disgusting, and inhumane things also. As McEvilley states, "The primitivism they projected onto 
Africans and slaves in America came from inside themselves" (55). Kara Walker is showing a side of history in art that has been suppressed by myth of the "happy slave" and the "singing darky." These images are prevalent in the images and creativity of the Antebellum South. In her narratives, there is nothing happy, good, or entertaining about slavery. Kara Walker positions herself as a trickster in the art world playing games with the observer's eye and mind. You may think you see something and then it disappears into an even deeper level of a complex story about the master and slave relationship. Walker's trickster approach to her art is even seen in the way both Black and white people view her, "It is ultimately impossible to tell which side Walker is on. White people feel she's on the side of black culture yet somehow able to share their point of view too; black people feel she's on the side of white culture, though again able to see the opposite point of view (59)."

Instead of Walker keeping her images to herself, she shares them with the world, "Walker's images are indeed sexualized, confrontational, and racist, because the entire Western world shares these images in our waking dreams and nightmares" (31). So could the reaction that she receives for her provocative work is a manifestation of the fear of reality? Could it be the repression of sexuality in Western culture? This reality has been misconstrued in history with the idealism of the happy docile slave.

Sander's discusses the work of Jewish artists who use Jewish stereotypes that are anti-Semitic to reveal those images and create a new Jewish form of expression (31). Is Kara Walker's black paper silhouette also a tool to reveal those Black stereotypes that still affect the Black community today, to raise awareness of their existence by creating a new form of Black expression? Sanders asks the question, "Is Walker's art "too racist"? 
and mentions the chatter about whether or not she is "good for black people?"(31). However as Sanders paraphrases Julia Kristeva's book Power of Horror: An Essay on Abjection the idea of how being an image of other affects the Western world:

It is the imagery of that which we define as residing at the margins of Western "normality": the corpses, the amputee, the slave, the Jew. Evoking these images triggers our gut reaction, which repels, rejects, or repulsed. It confronts viewers with a clear representation of what we must abhor but always imagine that we are capable of being indeed might already be (32).

Kara Walker's work shows a side of America and even a mental capacity that seldom creeps to the surface. Are all of these putrid images she creates for the world just a figment of her delicate imagination? Maybe, "racist imagery has been repressed by both white and Black Americans, and she is forcing it back into the forefront of consciousness" (McEvilley 61). According to Sanders, "[Art] takes the dream narrative and images from our experience of the world and makes them resonate in the imaginary space of the creative. It is the "day residue," the visual experience of our lives, our history that provides the external forms with all their power, horror, and abjection" (33). How is Walker's work a form of optimal consciousness if she has so many critics who do not want to see her art work, and find it derogatory to Black people or has described her work as pornography?

Kara Walker is a silhouette artist whose work explores race relations in the Antebellum South. Her artwork breathes, defying the objectification process that happens in museums. When describing her work, curator Hamzo Walker affirms that she "More than engages history, Walker's work inhabits history. In this respect, the work itself is a 
form of role playing, a preposterous historical reenactment of which Walker is the narrator" (Walker 274). Her ability to manipulate history with her living silhouettes is a spiritual quality juxtaposed with the secular atmosphere of the museum. Though her work is contained, it is still free. In one of her exhibitions you will see quaint images of the Civil War, such as the glorification of the soldiers and their lifestyle usually depicted of soldiers proudly marching to battle and living on the wild frontier. Yet this proud moment is broken with a black silhouette figure shaped as the Black mammy, the pickanny, or another sambo doing something absurd like possibly being fondled by their white master. As an artist, she does not want anyone to forget that this time period of American expansion had another internal war going on; one that is not just between the North and South, but Black and White, Nigga and Ma'am, sir and boy, mistress and master. A hostile time period which she acknowledges has contributed to the formation of society as well. In describing her thought process when creating her art pieces, she keeps this statement in mind, "How do you make a representation of your world given what you are given?" (pbs). An important aspect of raising-consciousness is the acknowledgement of truth even when it is hard, and Walker definitely leaves no secrets.

Though she chooses harsh images for the eyes, her work can be seen as a form of encouragement to Black people. She shows a side of history that has not been thoroughly told adding her own mythology and creative spin to it. She creates caricatures of images seen on pancake boxes or rice products, and gives them weapons like table knives to kill the white master of oppression. She does not show Blacks in the antebellum South as only victims but as human beings who had agency over their situation as well. Those 
images alone can give a Black viewer a sense of empowerment. Slaves did not always play the passive role, they also killed!

W. E. B. Du Bois during the Harlem Renaissance "advocated art for racial uplift" (Shaw 28). He was a part of a magazine, The Crisis, founded by the NAACP, supported Black artists who contributed to the community (28). Visual art as racial encouragement can be seen in the Harlem Renaissance in the silhouettes which were drenched in African motifs. At the same time, though her work is speaking on racial issues, it is not going to always be accepted by the Black community as seen in her conflict with older Black artists. But just like in the spirit of Langston Hughes who just wanted the freedom to make art without the validation of anyone, Kara Walker can be seen the same way as demonstrated in Hughes' quote, "If white people are pleased we are glad. If they are not, it doesn't matter...If colored people are pleased we are glad. If they are not, their displeasures doesn't matter either. We build out temples for tomorrow, strong as we know how, and we stand on top of the mountain, free within ourselves" (31).

Kara Walker's work has been described as racialized pageants and minstrelsy, but intellectual Henry Louis Gates believes what she is doing is phenomenal and necessary for the people even though she is using the images of the sambos, coons, mammies, and jigaboos:

These artists are seeking to liberate both the tradition of the representation of the black in popular and high art forms and to liberate our people from residual, debilitating effects that the proliferation of those images undoubtedly has had upon the collective unconscious of the African American people, and indeed upon our artists themselves and their modes of Representation (36). 


\section{India. Arie}

In discussing the many functions of the common historian and story teller in an African society, author of Griots and Griottes states "[g]riots prompt people to immediate action by their words" (Hale 40). The smooth words that India. Arie sings with her guitar have the same ability to move one towards action. Many recognize the griot as a storyteller and musician but their roles were vast including a genealogist, advisor, spokesperson, interpreter, translator, musician, teacher, warrior and beyond (Gleason). As an advisor, the griot helped patrons, rulers, to name a few (24). In describing the music of the griot, Hale states "[t]he music the griot produces is in some ways the external manifestation of a highly complex and synergistic process surrounded by mystery" (36).

The youngest of the triad of artists, India. Arie holds the jewel to knowledge. She is the keeper of tradition. Within her songs are words that motivate, educate, and provide moral standards for the community. She takes what she has learned from her elders and gives it to the world. She stands on the shoulders of her ancestors who give her understanding.

India .Arie begins her first album, Acoustic Soul, giving gratitude to her ancestors before she enters into her songs, "This is in remembrance of our ancestors" (Acoustic Soul). In between her lyrics there are gifts of wisdom called interludes that you will find on all four of her albums. The interludes are just as beneficial as the songs. For example on her album Acoustic Soul, one of her interludes says, "the only thing constant in the world is change..." and that by itself may be just as healing to the listener as a whole song. Her music is usually positive and encouraging and is infused with core values such 
as family, relationships, spirituality, and love. There is an emphasis on the message when it comes to the lyrics of India. Arie, her words can be medicinal to the ears. Her music is usually classified as neo-soul.

Neo-soul is a "musical genre that fuses contemporary R\&B and 1970-style soul with elements of hip hop" (Nero). It was coined in the mid-1990s and has been described as "evocative yet poetic lyrics and a style that was strangely reminiscent of decades past" (Ayanna G 1). Kedar Massenburg of Motown Records is believed to have coined the phrase "Neo-Soul," though the sounds were already surfacing previously in the early 1990s with artist like Raphael Sadiq (Nero) The re-emergence of soul music in the 1990s is thought to be a reaction to the technological sounds introduced in the 1980 s and a longing for a more authentic music that resembled the stirring lyrics of Motown or the heart wrenching strum of the blues guitar (Ayanna G 1). It is soul music that is catered to the "attitudes and sensibilities" of today, yet also retains a "deeper message and meaning than other popular music" (Nero). Massenburg is also believed to have influenced the musical career of India. Arie through her first record deal at Motown. In 1995 D'Angelo's Brown Sugar, and Erykah Badu's Baduizm in 1997 continued to bring Neosoul to mainstream music in America (Nero). Though these artists have enjoyed "crossover" success, many neo-soul artists do not cross over because of their emphasis on artistic expression versus the pop cultural appeal (Nero). However some artists believed to have influenced mainstream music, while still maintaining their soulful qualities are artists like Lauryn Hill and following her, India. Arie. According to neo-soul critic Nero, some artists believe that their music cannot be classified as Neo-soul, because there is nothing new about what they are creating for the public (Nero). They would rather call 
themselves "soul musicians" and create albums like Jaguar Wright's Divorcing Neo to Marry Soul to further express her autonomy and self definition as an artist (Nero). Places such as Philadelphia have been considered the root of the Neo-Soul movement especially with its long history of Black music, "During the 1990s and today, a subsequent generation configured a new hybrid of soul with hip-hop. Musicians and producers like the Roots, Bahamadia, King Britt, Jill Scott, and James Poyser have made Philadelphia a center for a distinctive African-American club music that uses live instruments more than drum machines" (Hodos).

India. Arie has been classified as an integral part of Neo-Soul music. Her mother Joyce who was a fashion designer and soul singer, opened for legends such as Stevie Wonder and Al Green. Her father, Ralph Simpson, was a NBA player (askmen). India. Arie was named in honor of the peace activist Mahatma Gandhi from India since their birthdays were near each other (Waldron 60). India Arie Simpson was born October 3, 1975 and Mahatma Gandhi October 2, 1869. She grew up in southern Atlanta though she was born in Denver (Waldron 60). Her mother said that her middle name Arie was randomly created from her thoughts; India later found out that it meant Lion (60). Her name had both the elements of a roaring lion and the gentleness of a nonviolent peace activist. India. Arie followed her musical pursuit when she was a child by singing in the church and playing instruments such as the saxophone, clarinet, and trumpet (60). When reflecting on her high school years she remembers not being the "popular one," she had an old school spirit that would listen to Donny Hathaway instead of Bobbie Brown (Waldron, "Hit Singer" 64). 
It was not until she entered The Savannah College of Arts and Design that she was introduced to her signature instrument, the guitar, and she attested "It was the first instrument that I could sing with..." (Waldron 61). Her idea to pursue jewelry creation at the acclaimed school did not last long because music called to her heart more. She soon left Savannah College of Arts and Design and co-founded a collective for artists in Atlanta called Groovement/Earthseed, which was followed by a record deal with Motown (askmen). In 2001 she created her first album, Acoustic Soul. Her first single Video brought her to the forefront with the catchy hook, "I am not the average girl from your video, and I ain't built like a supermodel, but I learned to love myself unconditionally, Because I am a queen..." (Acoustic Soul). The lyrics spoke to her acceptance of herself in a world that emphasized artificial beauty standards. Video set the creative tone for India. Arie, Her songs that followed continued to spread words of encouragement, truth, and straddled the line of both sacred and secular music.

In describing Acoustic Soul, her first album she mentions, "My album is inspired by the power of words and knowing that the things you say are a motivational force. The more you say something, the more it creates the energy around you. The words that come from your mouth go into your ears. Speak words of beauty and you will be there" (Waldron 590).

India. Arie already had an understanding of Nommo, "the generative power of the spoken word" (Jackson and Richardson xiv). Nommo is originally from the Dogon people of Mali and means "word", it was incorporated in the African American experience in the 1960s by Molefi Kete Asante as a conceptual framework and a way to comprehend African American rhetoric, and communication in general (Jackson and 
Richardson 8). In the Dogon creation story, "nommo" was sent by their creator Amma to "complete the spiritual and material reorganization of the world and to assist humans in the forward movement of history and society" (8). They are also deities, the first beings of creation, and ancestors of human beings. India. Arie displays epic memory in her statement about the potency of words, using the power of Nommo with ease as she creates her lyrical and musical masterpieces.

Throughout Acoustic Soul and the rest of her albums, there are raindrops of positivity in each song with lessons to be shared. Her pure thoughts on music, "I had a dream that someone said: 'Artists help people stay in touch with their feelings.' I think music has the ability to heal, the ability to destroy, to teach. It's a very tangible/nontangible thing... it just goes. It's like pure energy that lives forever"' (India.Arie).

Within that quote she speaks of the fusion of the sacred and secular and the encouragement she feels as an artist, which are elements of optimal consciousness. The healing power of music can be seen in the function of traditional African Art, its use during slavery in the Americas, the Harlem Renaissance, the Black Arts Movement, and continues today. The ability to heal through music is usually categorized as spiritual in a Eurocentric worldview, but the sacred and secular experience of music is intertwined in her songs. For India. Arie, her music is spiritual, and she does not have to mention God in her songs for her audience to feel that transcendent experience as expressed in optimal consciousness. In illustrating the fusion of sacred and secular, the song Always in My Head is dedicated to her spiritual relationship with music. When describing her music she believes, "my music is very spiritual. I know how I live music. I sing all day. I think about what the healing power of sound is..." (LiveInBrazil). 
In a magazine interview she stated, "When I first started writing songs, I knew that I just wanted to say things that were uplifting, because if I was going to sing them over and over again, why not make it something that feels good to sing" (Strejcek). She pays homage to Stevie Wonder in her song Wonderful, which also gives adulation to her ancestors. Paying homage is another traditional function of African art. Stevie Wonder reciprocates the gratitude by mentioning, "A gentle genius lives in the mind, voice and hands of this woman", India. Arie (Waldron 62). Also her second album Voyage to India is named after one of Stevie Wonder's songs on A Journey, Secret Life of Plants.

Within an African centered approach to creativity music has the power to transform the consciousness of its people and India. Arie's music inspires many to do that, however a "Eurocentric controlled recording and distribution industry will not allow this to happen" easily (Richards 72). Capitalism plays a heavy role in creation of contemporary American music. For example, if an artist is not number one on the charts or her album is not platinum or gold; she has no value as an artist. As written by Mark Anthony Neal in Songs in the Key of Black Life: a Rhythm and Blues, The bottom line is that contemporary $\mathrm{R} \& \mathrm{~B}$ and the radio and video programmers responsible for making that music available to listeners and viewers remain trapped in a small box largely informed by hip-hop bottom and Blige-like histrionics with small traces of Luther and Whitney and enough tone deafness to have Clara Ward, Mahalia Jackson, and Sam Cook turn twice in their graves about every four and a half minutes (I could be talking about Ashanti, but let's be real: it ain't just her).

India. Arie was successful in selling albums because her first platinum plus album Acoustic Soul sold more than two million copies. Her second album Voyage to India 
(2002) won her two coveted Grammy Awards, and Testimony: Vol. 1, Life and Relationship (2006) was number one on the Billboard charts. Also for her last album, Testimony: Vol. 2 Love and Politics (2009), she won a Grammy for her rendition of Sade's Pearls in the best urban/alternative category (India. Arie).

Arie's journey was not an easy road to success. Though nominated for several Grammy's for her first album Acoustic Soul and her signature song Video, she did not win any of the 8 Grammy nominations. At the Grammy Award show in 2002 Alicia Keys won five Grammys, and though India. Arie was nominated for seven, she was "shut out completely" (Lammers). Some believe that India. Arie and Alicia Keys both represent Neo-soul music, yet Alicia Keys music caters more to pop cultural ideas and this style may be the answer to her more mainstream acceptance. Neo-soul is a genre of music that has an emphasis on meaning and message, Alicia Keys song Fallen that was in competition with India. Arie song Video, lyrics displayed nothing new when it came to what had already been created musically. Fallen lyrics were, "I keep fallin in and out of love with you..."; it was a song about a man and woman who are going through the common R\&B theme of relationship struggle. Other songs that were popular in 2001 that dealt with relationship struggle were Blu Cantrell Hit 'Em Up Style (Oops!), Shaggy It Wasn't Me, and Destiny Child's Emotion (2001 Billboards). In contrast India. Arie's song Video was one of the few songs that talked about a self love and inner beauty, a message that was definitely lacking in the music industry in 2001 .

Another factor in the 2002 Grammy selections is the role that image plays in the music industry. India. Arie has a dark-brown complexion with a slim slightly muscular build and dreadlocks who wears clothes that her mother made and played the guitar; 
whereas Alicia Keys is light-skinned and petite without a muscular build, who kept her naturally wavy hair in braids, and played the piano. The music in Fallen was inspired by Beethoven's Moonlight Sonata (Alicia Keys Fallen). There was nothing really innovative about Alicia Keys, both her music and lyrics were recycled. However, this did not stop her from winning five Grammys.

India. Arie was challenged after her Grammy loss, and took a different approach when creating her album Voyage to India .She realized that she had to go back to the little things, and not worry about the societal validation of her work as an artist. On that second album her song Little Things discussed how the joys of family and friends are more important in the world than the luxuries of life. It was affirmation to herself and her fans that nothing like an award should define or validate her. She eventually won two Grammy Awards in 2003, one for Voyage to India, the album and the other for the song Little Things.

In the mainstream music industry in America, she is considered opposite of the artists like Britney Spears and Lil Kim whose music is lathered in sexual innuendos, materialistic dreams, and individual sorrows. Her music is corrective, used to make people feel better and not cater to their egos.

In optimal consciousness, music or aesthetics that derives from Spirit captures an audience with their spiritual interaction experienced through their creative expression. The Nzuri Model explains that Black artists who incorporate the functions of an African centered art transcend geographical boundaries or any boundaries period, and this is demonstrated when India. Arie goes to Brazil. Though she cannot speak Portuguese, she is able to communicate with the people through her music. 
She is a UNICEF (United Nation's Children Funds) ambassador and activist for human health and human dignity, her song What About the Child has been used for UNICEF events (India. Arie). Her song She Is was created in honor of the current president of Liberia Ellen Johnson Sirleaf and her Beautiful Flower helped raise money for Oprah's school in Africa (India. Arie). India. Arie has also collaborated with actress Ashley Judd to raise money and awareness for AIDS in Africa (India. Arie).

Though she can be labeled as an alternative or Neo-soul artist, in an African worldview she is also considered an griot. As a griot, she is an "oral historian and musician", and on her songs you do not only find motivation, but history as seen in the lyrics of India's Song (Griot).She is an griot because she relies on the community and her experiences to create music. The community expects her to deliver her experience as a way of teaching and encouragement. India. Arie provides a rare example of a contemporary Black artist who has negotiated her rhythm within her own culture, and outside of her culture, into the mainstream music industry. She also now has her own record company called Soulbird which allows her total creative agency over her work and provides assistance for other artists (India. Arie).

Music has the power to transform the consciousness of its people and India. Arie's music achieves this. She is a global artist that is on a mission to change the world with her words and guitar. Many of her songs can be used to demonstrate optimal consciousness, yet this research discusses one "Video", along with her music video that accompanies it. India. Arie ends the background conversation of the triad of artist, now there will be analysis of how their work representative of optimal consciousness. 


\title{
CHAPTER VI
}

\begin{abstract}
ANALYSIS
By demonstrating how the works of Shange, Walker, and Arie are authentic, a fusion of the sacred and secular, and promotes positive interpersonal relationships---proof of optimal consciousness will be exhibited. As an artist, the knowledge accumulated assists me in my criticism of their artistry ${ }^{2}$ because of my shared creative experiences. As a patron, my responsibility is to promote understanding and appreciation of the artists by viewing or listening to their original works and responding in affirmation or questions (Welsh-Asante 15). With the collaboration of the interdependence of the artist, critic, and patron informed introduced by Welsh-Asante--this analysis uses optimal consciousness, an Afrocentric framework that allows healthy criticism of the creative expressions of Shange, Walker, and Arie. In return, the artists can use this feedback that can be beneficial to their work.
\end{abstract}

\section{AUTHENTICITY}

According to Linda James Myers's theory optimal consciousness, "[ $t]$ rue artisans feel empowered by what is within. Technicians replicate the externalized products of others" (Myers, Optimal Consciousness 181). This provides the foundational definition of authenticity with its emphasis on originality. The following works will be explored using an understanding of the definition and scope of authenticity that was abbreviated above

\footnotetext{
${ }^{2}$ See CV for list of the author's creative works.
} 
and explained in Chapter II: Shange's choreopoem For Colored Who Have Considered Suicide When The Rainbow is Enuf, Walker's silhouette narrative Gone: A Historical Romance of Civil War as it Occurred Between the Dusky Thighs of a Young Negress and Her Heart, and Arie's song "Video."

\section{Ntozake Shange's Choreopoem}

For Colored Who Have Considered Suicide When The Rainbow is Enuf expresses a story on womanhood, love, rape, and history, creatively intertwined in a fluid framework that uses poetry, prose, song, dance, and music collectively (Lester 9). It also provides one of the first platforms where black women could openly discuss their experiences uncensored. There are several women in the piece who are named after the colors in the rainbow. Each woman takes the audience on a journey of their life that is infused with memories that vary from joyful to horrid situations causing death. Most of the stories presented discuss women's interactions with men such as experiences of one losing her virginity to another's grief over her ex-boyfriend killing their kids for revenge. Another monologue exhibits a women's agency, as she sleeps with men and then leaves them for the pure joy of it. While another tale mentions a little girl's affair with a historical figure in a book--Toussaint L'Overture. The scenes are diverse enough in For Colored Girls Who Have Considered Suicide When The Rainbow Is Enuf that most women can find something to relate to which has contributed to its staying power today, almost 40 years later.

Since Shange wrote this herself, it is a testimony to the authenticity of it. This demonstrates the originality of the text that is based on her ideas. Shange even coined the framework of her creative idea as a choreopoem. Shange explains, "[a]s opposed to 
viewing the pieces as poems, I came to understand these twenty odd poems as a single statement, a choreopoem" (Shange xiv). In describing how she began the work she comments, "[i]n the summer of 1974 I had begun a series of seven poems, modeled on Judy Grahn's "The Common Woman", which were to explore the realities of seven different kinds of women. They were numbered pieces: the women were to be nameless $\&$ assume hegemony as dictated by the fullness of their lives" (Shange xii). Just like Grahn, Shange uses colors instead of proper names to deemphasize the individual and highlight the collective of women of color experiences.

Another instance of the authenticity of the piece is that the choreopoem is not inhibited by the structural standards of the English language or western theatre; she uses her own conventions. This is demonstrated from the beginning with the title For Colored Girls Who Have Considered Suicide When The Rainbow Is Enuf. One may notice the obvious misspelling of the word "enough" as "enuf". The title is not a complete sentence but more of a stream of consciousness. Also her context of rainbow expands to mean something more than simply the bright arch of multiple colors after it rains, but also a metaphor for the variety of these women's experiences. Throughout the work readers will find that the rules of the English language are purposefully neglected in order for her to have dominion of her authentic space.

The pieces in the poem are also autobiographical. Shange, who was a professional dancer, mentions in several of the monologues the characters moving to the music. Lady in Yellow dances to the Dells, Lady in Blue does the Salsa, and all the colors use creative body movements throughout the piece. For example Lady In Yellow says, "we danced doin nasty ol tricks..." (Shange 9). While lady in blue mentions, "so off I made it to this 
36 hour marathon dance con salsa con ricardo" (11). Most of the short stories have some type of dance movement in it. Shange even literally refers to herself in a monologue within the choreopoem by lady in green that famous phrase is "somebody almost walked off wid alla my stuff" describing how she felt after a man nearly left her with nothingemotionally and materially speaking. Lady in green declares, “I didn't bring anything but the kick \& sway of it, the perfect ass for my man \& none of it is theirs, this is mine, ntozke 'her own thing'/that's my name/now give me my stuff' (50). This provides the audience with a raw image of her; she does not hide behind an artistic shield, adding to the authenticity of the piece. The direct reference to herself in this piece illustrates the intimacy of the work to her own life, authentic. The monologue about Toussaint L'Ouverture shows a glimpse of Shange's childhood as a little girl who despises integrated schools in St. Louis and declares her love for books, "Toussaint waz layin in bed wit me next to raggedy ann, the night I decided to run away from my integrated home, integrated street, integrated school, 1955 waz not a good year for lil blk girls" (Shange 27). The girl in this monologue is 8 , exactly the same age Shange would have been in 1955 Also the title itself, For Colored Girls Who Have Considered Suicide When The Rainbow Is Enuf, reflects her own life since she had attempted suicide four times while in her mid-20's (Cordova). Also within the title there is a term of endearment that her grandmother use to call her, "pretty little colored girl", therefore she used "Colored Girls" in her title (Cordova). She continuously refers back to her own life experiences, validating the authenticity of her work. Her life is woven throughout the choreopoem and her art provides a framework. 


\section{Kara Walker}

Kara Walker's silhouette narrative entitled Gone: A Historical Romance of Civil War as it Occurred Between the Dusky Thighs of a Young Negress and Her Heart is inspired by the Margaret Mitchell novel Gone With the Wind, published in 1936 and produced as a movie in 1939 (Raymond 348). The novel takes place in 1861 and is described as a "mythologized depiction of the period as a genteel and benevolent agrarian society, permanently fixed in the American psyche, a distorted account of the American South" (Raymond 348). The book is known for its romanticized version of the antebellum South. This same twisted depiction of the South is seen in the nineteenth century painting "The Old Kentucky Home-Live in the South (Negro Life at the South)" 3 by Eastman Johnson, presenting what appears to be a normalized view of the happy slave. Yet it further expresses "the myth of a harmonious rural life while disguising the inhumane treatment endured by slaves..." (Raymond 348). On the other hand, Walker reveals truth in her work through her exaggerated images presented.

Her silhouette Gone: A Historical Romance of Civil War as it Occurred Between the Dusky Thighs of a Young Negress and Her Heart begins with a wet, swampy landscape (see appendix). It seems to be midday by the way the sun is displayed with a partial cloud covering it. There are two young white lovers in secrecy behind a tree that provides them with protection from observers. They are both dressed in clothing of the period. She has on a hoop skirt and by the extreme smallness of her waist, it is clear that a corset is underneath. The young lady wears a long -sleeved blouse, a sign of elegance. The epitome of beauty is even graceful in her attempt to kiss the young lad.

\footnotetext{
${ }^{3}$ Esaak, Shelley. "Eastman Johnson's Old Kentucky Home (Negro Life at the South), 1859". About. Web. August 2010.
} 
Her tresses are in a lovely ponytail and her hands make a delicate gesture, her boots are even fashionable. The lad is distinguished in his posture that is commanding; his chest protrudes to show his strength and power. The upper body is covered with a long jacket that is lightly embellished and an intricate fancy collar accents his attire. The cropped haircut is nice and neat, and he wears knee high boots in which his pants are neatly placed inside. Behind his back he holds a long sword in acknowledgement of his gentleman character to keep his love interest from violence. Everything is blissful in the marsh-like land, and you can see the sweetness of their romance. This is the antebellum South that is romanticized---the summer heat, sweet romances, the quaint couples, the natural beauty of the trees, and tall green grass.

However, there is more in Walker's silhouette narrative and optimal consciousness values the authentic, the truth. Though these images of the good life did occur during the antebellum South, there was another institution during this time period: slavery. As the nice young lady leans over to kiss the gentleman, you notice an extra pair of skinny legs hiding underneath her skirt. This is the beginning of Walker's construction of her interpretation of the forgotten world of slavery in these romanticized stories and portraits of the antebellum South. It appears to be a small scrawny slave child who is barefoot. It seems like the young mistress is getting satisfied orally by the slave who is underneath her dress, while attempting to kiss the gentleman simultaneously. Behind the gentleman, at the tip of his sword that also looks like an elongated phallus, there is another naked black slave-like image, that the appears to be female. The tip of the sword almost enters behind of the slave who is facing the opposite direction towards the water. This alludes to the sexual cunningness of the slave master and his mistress, and the 
exploitation sexually that occurred to the slaves. According to Walker's silhouette, it did not matter if it was the mistress of the master making those advances. Commonly, when sexual exploitation of the slave is mentioned, the white man was the culprit, however Walker's images illustrate white women exploiting as well.

The slave girl who is turned towards the water has two pig tails that are turned upward contouring to devil horns. While standing at the edge of the land where a body of water begins, she holds a dead bird tightly by the neck, illustrating that she is going to eat the chicken. At the same time the chicken neck also looks like a phallus, in which she could be partaking in sexual favors. The slave-like girl looks like she is groping a chicken which has also been associated with masturbation..."choking the chicken".

The first part of the silhouette narrative is my focus of the study, however the piece is full of thought-provoking images. The next image is even more vivid; there is a little white boy standing near the edge of a tall piece of land or hill with his hand reaching towards the sky while a little girl sucks his manhood. If you follow the little boy's hands towards the sky, you notice that he is reaching for an ambiguous slave human, man or female, that has an engorged penis. Right below that image, there is a pickaninny giving birth to two little babies carelessly. There is also a white man whose head is under the skirt of a black slave woman satisfying her orally, juxtaposing the first image with a slave under the dress of the white women doing the same act. With each image, you are introdcued to the twisted ideas of the South that were left out in the romanticized version; Walker's authentic world.

Kara Walker creates her own view of the antebellum south that is juxtaposed to popular belief. Just as the idea of the antebellum South's loveliness is exaggerated, she 
emphasizes the perception of black slaves being over-sexualized creatures, animals, and subhuman. That depiction was a truth of the time period that was ignored in the romanticized views of Gone with the Wind and Eastman Johnson painting "Old Kentucky Home (Negro Life at the South)".

Even the way Kara Walker creates her silhouettes reveals a degree of authenticity. She draws the images on the reverse side of the paper and then cuts it simply with a pair of scissors (Golden 47). It is her hard labor that creates the images into wonderful masterpieces. In describing why she cuts, Walker states, "I can't get my hands around technologically assisted fabrication, not yet...cutting feels more like drawing" (48). It gives her more freedom to be creative. She uses her hands and scissors to create these whimsical silhouette narratives that are displayed in prestigious museums around the world. She does not use the shield of technology within her work; she cuts out the middle man which pulls the audience closer to her work. With today's advances in technology, she could have easily used the latest art software to create and enhance her images, however she chooses not to--Walker did it herself, authentic!

Another aspect of her authenticity is seen in the titles and note cards of her artwork. When describing this feature of her work she mentions, "[n]arratives are very important to my work. I appropriate from many sources...frontispieces for slave narratives, authentic documents, as well as a novel are a great sort of artistic spectacle" (47). This demonstrates her process of finding the right text to accompany her figures in her artwork. A historical accuracy is manifested in her titles and note cards through the research that she does. For example the work that is being analyzed in this research, Gone: An Historical Romance As It Occurred Between the Dusky Thighs of a Young 
Negress and Her Heart is her own spin on the novel about the antebellum South Gone With The Wind and her fascination of the labels and roles of black women throughout history. Also just as Shange's title, Walker's title moves away from the conventions of the English language and uses a title that sounds more like a stream of consciousness or several run-on sentences put together.

Walker even has given herself an alter ego that she calls "the nigger wench" that embodies her own sentiments about history and the work that she does. Unlike Shange who states her name in her piece, Walker uses a character she created to embody some of her sentiments. While some might argue that this alter ego distances Kara from her work, the harsh realities that "the nigger wench" seeks to expose make her character seemingly more raw than perhaps the construction of Kara Walker as a popular artist would allow. In describing how she came about with the name "the nigger wench" she declares, There was so much identity-based art, and I had not really taken stock of where I was and who I am and who it is I'm looking to define me. It was always coming from outside sources. That's how the nigger wench came to have a name. She didn't have a clear identity, but as I pursued literature and cultural studies and essays, reading everything pertaining to black women, this characterization became clear (45).

Kara Walker references the book The Clansman through the character called the tawny vixen as one of her creative muses. She mentions how she was more interested in the black female figures throughout history that were "somewhat mischievous and evil" (45). She describes the tawny vixen as "catlike, trying to influence the powers that be 
with her wily ways..." and further explains "[i]t's a persistent stereotype, the black woman whose powers overwhelm the "good" and the "just" white people" (45).

\section{India. Arie's Song}

Within the analysis of authenticity for India. Arie's work, there are two media that are being explored—the song "Video" and the music video that accompanies it. Video was released in 2001 and quickly became a hit and the album Acoustic Soul went double platinum. The catchy phrase "I'm not the average girl from your video...," became an anthem for women learning to appreciate their inner beauty and asserting their individuality. Though India. Arie was known for her soulful lyrics in small circles, "Video" pushed her into mainstream even though her whole persona was the antithesis of popular culture. The song "Video" provides an intimate critique when it comes to authenticity, because she wrote the song based solely on her own experiences. Unlike Shange who wrote about a collaborative of women of color experiences or Walker who provides an historical framework to embody her creativity in the antebellum South; "Video" is all about India. Arie, her story, her feelings, no edits.

This is indicative of the frequency of the usage of "I" and "my", which directly speaks to the authenticity of the piece by literally referencing herself in her song like first artist Shange did in her choreopoem once. Not only does she use pronouns, but her name as well when she sings at the end of the song, "No matter what I'm wearing, I will always be India. Arie"(Acoustic Soul).

In her music video for "Video" Arie comes out of a house in a yellow sleeveless midriff-baring shirt. She wears a pair of blue jeans that are a bit flared with yellow sunflowers painted on them. For accessories, her ears are adorned with thin silver 
earrings and she wears a head scarf that is blue, brown, yellow, and orange that partially covers her lengthy dreadlocks. Her locks also go against social norms, when most images of black women portray straightened hair, either chemically or with a wig, she chose a natural hairstyle that has been associated with much controversy. On her arm are a few rustic silver bangles and a ring with a light brown jewel. She walks in some beige flat winter boots. Arie also has a netted large scarf that she wears on her neck and on her waist at times. Later on in the video her hair is adorned with a white flower. Her attire is full of natural tones like the yellow of the sun, white clouds of the sky, and green of the grass. She loves nature, and by her attire and later songs she expresses it. She has added her own individual touch to her garments, a stamp of her authenticity.

On the porch bench in the video, you see the words of her song lyrics "Video" on sheets of vanilla paper written in black cursive in reference to the originality of the piece. This is similar to Kara Walker's usage of scissors to cut her own silhouettes, her own effort. Her words are original, influenced by her own experience. Authentic is described as "higher refined energies directly from the spirit" that are seen through India. Arie's song lyrics (Myers, "Optimal Consciousness" 181).

She then puts her guitar on her back, and rides her red antique bicycle in the middle of the road on the yellow lines into town. This gesture shows that she goes her own direction; she rides in the middle of the street as the traffic goes in opposite directions beside her. She proceeds to what appears to be a vintage shop to buy some clothes. While outside looking on the racks, a group of supermodels were walking towards her. The women had on midriff-bearing tops, short skirts and shorts, and sexy and tight dresses. They were going to a music video audition in the same building of the 
vintage clothing store. While India. Arie was busy being an individual; the other women were auditioning to fit a stereotypical image of women that is accepted in the media. Arie's attire, by no means resembles what the other women are wearing. She goes to the video call and continued to flaunt her natural attributes while all the other women were trying to be sexy according to the standards of the society. The woman had to wear certain types of cloths, exhibit the latest hairstyles, and more. The theme of originality and individuality are continuously seen throughout the music video, revealing qualities of herself to the audience adding to the authenticity of the music video.

Popular music videos use women's bodies to attract viewers, most of the time women are almost naked and play the role of the male trophy, an expensive or cheap object. India. Arie refuses this role, by simply being herself and wearing her own creative garment.

Then she goes to stand on a billboard that says "India Queen Brand...Locally Grown with Acoustic Soul" which continues to attest to her originality. She has meshed her identity with her image, marketing to the world herself, no an object that has been created by the record companies. She also illustrates her name in the music video to let the viewers know that words that she sings are personal and intimate to her. The artistic shield is also removed in that instance revealing authenticity in her video.

Her song lyrics also show her authenticity. In the beginning of the song, she kindly removes the significance from her physical attributes, and states that she is informed from within and not by popular belief, "Sometimes I shave my legs and sometimes I don't, Sometimes I comb my hair and sometimes I won't, Depend on how the 
wind blows I might even paint my toes. It really just depends on whatever feels good in my soul" (Acoustic Soul).

Her direct reference to soul reveals her authenticity. That acknowledgment of her actions being spirit led by her soul (spirit) is representative of optimal consciousness. By rejecting the dominant society's notion of beauty, she accepts her own definition that is self-inspired. The chorus goes even further in her affirmation of herself, "I'm not the average girl from your video and I ain't built like a supermodel. But, I learned to love myself unconditionally Because I am a queen. I'm not the average girl from your video My worth is not determined by the price of my clothes. No matter what I'm wearing I will always be India Arie."

In the catchy chorus she tells her listeners that her body or appearance is not the prototype like the supermodel or video girls. In the video you can see this as you view the supermodel girls versus herself. She even affirms that she has learned to love herself unconditionally while living in a society that tells her she is not good enough. Not only does she love herself, she has pride and calls herself a "Queen." Through the nice harmony and guitar stroking, there is a rebellious woman challenging societal norms by first being true to herself.

The next stanza of the song further pushes this idea of her accepting herself in a world that openly rejects everything she stands for, an individual. She smiles and sings, “And I know my creator didn't make no mistakes on me. My feet, my thighs, my lips, my eyes; I'm lovin' what I see," acknowledging that she is perfect already without the alterations and add-ons and continuously affirms "I'm lovin' what I see." The description of the video provides some context and vivid imagery, but the song lyrics portray an even 
deeper depiction of the sincere message that she was trying to give the world. Then she directs the listener to do the same at the end of the song, "get in where you fit in...", showing her advocacy for individuality-create your own space!

\section{SACRED AND SECULAR}

The second criterion that is used in the analysis of Shange, Walker, and Arie's work is the fusion of the sacred and secular. Are these artists able to break away from the dichotomies that inform popular art? For example, can India. Arie's music transcend both popular and gospel music, and fit comfortably in the space that includes both? The fusion of the sacred and secular is the encouragement of the diunital of the spiritual and secular world. Myers believes that the fusion of these opposite components can provide a remedy to the negative effects the Eurocentric worldview has on the African mind. Myers further explains,

we must further break out of the bonds of conceptual incarceration imposed on intellectual imperialism of dominant culture, by no longer allowing the segmentation of ourselves, no longer allowing the segmentation of the so called sacred and secular. Not to make the sacred secular, but to acknowledge the sacred in the secular (same Source) and make the secular sacred (Myers, "Optimal Consciousness" 182).

Following is analytical criticism on how each artist is able to fuse the sacred and secular cleverly in their genre of art.

Ntozake Shange Choreopoem

In describing Shange's work and its connection to the fusion of the sacred and secular, Sandra Richards suggests that the combination of language, dance, and music 
creates mojos (Richards 3). There is no reference to a religion, or a specific god, but an acknowledgement of god as a higher power--one that is beyond the worldly hemisphere. In discussing the healing and spiritual element that occurred with this choreopoem Neal Lester confirms, Through the women's experiences with rejection, infidelity, and physical and psychological abuse, they--through a kind of spiritual though not a Christian rebirth--emerge triumphant, full of joyous independence and greater selfknowledge (Lester 7).

This quote displays the transformative element of the play within the womens' spirit. It shows how something as worldly as a play can have a spiritual element. Another element of the fusion of the sacred and secular is through Shange's use of Frantz Fanon's combat breath in her work (Richards 73 ). Combat breath can be likened to the struggle of the everyday on earth; in reference to Shange's work, it can be described as the "social and commitment to struggle...the fighting spirit" that is created from living in a constant state of subjugation (Richards 73). Scholar Sandra Richards puts the idea of combat breath in opposition of the divine qualities that emerge from pieces like For Colored Girls Who Considered Suicide When The Rainbow is Enuf, "[t]he diametric opposite of Shange's combat breath is the will to divinity whereby individual protagonists seek to transcend corporal existence in order to merge with natural, cosmic forces" (Richards 74).

However, according to Myer's conceptualization of optimal consciousness opposites can co-exist. The secular and sacred forces in Shange's work are not in opposition of each other but are fused together to create a whole experience. When 
Richards attests that Ntozake Shange's characters 'tend to feel that they must opt for one of knowledge over the other," it is more often the sacred and secular working simultaneously (Richards 74). Within the confinements of a Eurocentric perspective that dominates, it is easy to simply separate the sacred and secular instead of fusing them together.

The names of Shange's characters in the choreopoem also reveal aspects of the fusion of the sacred and secular. The women are not distinguished by common names, but by colors such as brown, yellow, purple, green, blue, and orange. The use of color is illustrative of a sacred element that parallels with the Yoruba views of performance. Dr. Morena Vega, also a priestess of the Yoruba tradition, discusses the importance of performance in sacred Yoruba traditions. Her performance theory is that art is more than just for entertainment, but it has a purpose to uplift, educate, and help transcend one to a spiritual realm, very similar to Linda James Myer's optimal consciousness. As Vega states,

Color's not color. Dance is not only dance, music is not only music. For some groups, it is more than music. Because if you're looking at the Caribbean, Latin America, Africa, it is a way of calling spirit ... popular expressions, they're all grounded in the spiritual context, coming from indigenous, traditional cultures (Burnham).

From that statement, one witnesses that there is always interconnectedness between the spirit and material worlds, something as simple as color has a major significance. 
Dr. Vega states in her article,"The Candomble and Eshu-Eleggua in Brazilian and Cuban Yoruba-Based Ritual”, "[t]he Yoruba and their descendents introduced an aesthetic vision that called the spiritual forces to earth through recitation of special prayers, performance of particular songs, dance colors, symbols and instruments" (Vega 154). Color, song, and dance are all used in the spiritual journey of For Colored Girls Who Have Considered Suicide When The Rainbow Is Enuf. In discussing the spirit of her poetry, she says, "[p]oems come on there own time: I am offering these to you as what i've received from this world so far" (Shange xvi). Her spiritual gift to us is her poetry. Also in the beginning of the piece, Lady in brown summons the black woman's voice in a way that opens the space for a spiritual experience "dark phrases of womanhood of never havin been a girl half-notes scattered without rhythm..." (Shange 3). It is the beginning of removing a curse with a black women's spell. Following this, each lady mentions a designation in the United States to show that there is some type of commonality among the women, summoning woman from everywhere to join this celebration of womanhood in a sacred manner (Shange 5). Lady in purple does a monologue about a prostitute named sechita and her dancing evokes a spiritual nature to the men in her audience as she is "perfomin the rites, the conjuring of men, conjuring the spirit..." (Shange 25). This is another monologue that exhibits a woman power, in her movements that are spirit led. Also sexuality and spirituality are usually two ideologies that are separated but sechita's dance is seen as a ritual dance, stirring the souls of the men. Towards the end of For Colored Girls Who Considered Suicide When the Rainbow is Enuf the women start to make discoveries that would lead to healing as Lady in yellow states, "it waz all I had but being alive \& bein a woman \& being colored is a 
metaphysical dilemma, I haven't conquered yet, do you see the point, my spirit is to ancient to understand the separation of soul and gender, my love is too delicate to have thrown back on my face" (Shange 45). She compares womanhood to a metaphysical or supernatural experience and even fuses the soul and gender, the sacred and secular.

At the end, all the women talk about what they were experiencing. Lady in blue discusses her healing process as "all the gods comin into me, layin me open to myself" (Shange 61). The laying of hands is a very spiritual action that is embodied significantly throughout the end of the play. It provides the transference of spiritual energy. For example, when at some churches, the preacher lays his hands on you, and at times you are filled with the Holy Ghost. The ultimate sign of the fusion of the sacred and secular is when the women take their worldly pain and turn it to a sacred and healing experience by saying "i found god in myself \& loved her, I loved her fiercly" (Shange 63). Through the experiences of these women, they are able to transcend the worldly affairs to a realm where they can reach deification.

\section{Kara Walker}

Within Kara Walker's silhouette narrative Gone: A Historical Romance of Civil War as it Occurred Between the Dusky Thighs of a Young Negress and Her Heart there is an illustration of the co-existence of the sacred and secular. In the water there is a black young lady whose body is shaped like a boat. She has been described as "a ghostly half woman, half boat figure drifting across a body of water..." (Raymond 355). The woman is described as half spirit/half boat; it is a depiction of the union of the material and spiritual world literally. The half ghost/boat woman points almost motherly to the black child-like creature as to tell it, not to do anything with the dead bird. The water that is 
near the slave-like child and the location of the half ghost/boat woman also symbolizes a spiritual essence. Water signifies the middle passage, loss, mystery, and fragmentation (Raymond 354). This idea is further endorsed,

In Walker's allusions to water, the Atlantic Ocean is the original sacrificial site where her characters engage in psychological and physical abuse in order to exorcize the horrors of the contaminated waters that feed the collective ancestry of Europeans, Africans, and Americans (Raymond 355).

The idea of water as a representative of a sacrificial and sacred site of the slaves-a place of exorcism---provides a spiritual /sacred element to water that is fused with the secular function of it. Exorcism is the removal of evil spirits; water provides a place for this to occur, while providing a place for purification of the souls simultaneously. Scholar Henry Louis Gates expresses that the work of Walker demonstrates how "the black object has become the black subject in a profound act of artistic exorcism" (Wagner 93). The whole image of the beautiful antebellum South becomes haunted with the images of the slaves inside the picture. This haunted experience is a spiritual component, her work has the ability to reach the spirit of the viewers and cause an "emotional internalization" just as For Colored Girls Who Considered Suicide When The Rainbow Is Enuf did for its audience members. Also just like Shange's choreopoem, Walker's images combine sexuality and spirituality in the explicit scenes between the whites and slaves. For example the slave-like girl who is holding the chicken or "choking the chicken" (signifying masturbation) can also be performing a spiritual ritual with the chicken blood over the water (see appendix). The fusion of sexual and spiritual connotation is evident. 
Walker also alludes to the spiritual guidance that she receives from her work in this following comment,

My cousin has this joke which he transferred to me in which he tells the ghosts to "shut the fuck up while I'm working." But now I have decided to not let them be quiet and to engage the potential ghosts, so I'm not sure if it's just my own psychosis or if they actually hold the answer (Golden 49).

Her verbiage on interaction with the spirits when creating her material silhouettes is a fusion of the sacred and secular. She discusses how while she is creating art in the material world she is assisted by a ghost of the spiritual world.

\section{India. Arie's Song}

Arie's music video and song for "Video," also demonstrates the fusion of the sacred and secular. Towards the end of the music video, India. Arie walks in between the orange trees where she sees an elderly man picking an orange. Upon seeing her he puts one in her hand while she sings, "I was given a life learn lesson I was sent to share with ya'll..."(Acoustic Soul). The orange symbolized the knowledge that the older man was passing down. Elders are living representatives of ancestors and are considered very spiritual beings, sacred. The orange is usually seen as a fruit that someone eats, but in "Video" it becomes an emblem of food for the soul contributing to the fusion of the sacred and secular along with the living ancestor.

Also two lines within her song Video reference spirituality, "It really just depends on whatever feels good in my soul" and "What God gave me is just fine" (Acoustic Soul). This song openly speaks about spirituality in a song about self. Within this song she discusses how she is not going to conform to what a woman should be and create her own 
identity that is spirit led. Though these incidences are subtle, they are powerful indicators of the fusion of the sacred and secular. It is illustrated within the short music video and song that is only about three minutes and forty-six seconds.

When India. Arie traveled to Bahia, Brazil she also mentions the spiritual element of her music,

One of the main reasons I wanted to come to Bahia...Bahia is very spiritual, my music is very spiritual and I know how I live music...I sing all day...I think about it all day...I think about what the healing power of sound is... What it has been in my life...What more I can learn about it...And here spirituality is very infused in everything it seems...And for that reason, I am here...(India. Arie in Brazil).

Within that quote she mentions several things that eludes to the fusion of sacred secular in her music. She discusses how the grounds of Bahia, material, are in fact spiritual, which enhances her own spiritual experience while there. Arie mentions the ritualistic way that she sings, "everyday". In the video she also mentions her song called India's song was written in appreciation of her and how the ancestors helped her grow (India Arie in Brazil). Her life is a living testament of the fusion of the sacred and secular.

\section{POSITIVE INTERPERSONAL RELATIONSHIPS}

The last criteria of optimal consciousness that will be discussed are positive interpersonal relationships. This allows everything to have "the potential to be on one positive accord" (Myers, "Optimal Consciousness" 182). Interpersonal relationship is defined as "the relational context of interaction and the type of expectations that communicators have with one another" (Interpersonal Relationships). Myers gives an 
example of an interpersonal relationship as, "[t]he call/response pattern so common to all aspects of Afrocentric communication emerges from this relationship between the communicator, the communicated and the listener/receiver" (182). When experiencing the work of Shange, Walker and Arie the audience is experiencing the same thing, which allows them to be on one accord simply by knowing the basic role of the communicator/artist. The artist expects the audience to view, listen, or receive their art and the audience wants the artist to give them something to experience. The positive interpersonal relationship can come from knowing the basic roles the communicator has with the audience. They are not limited to exchanges among people, but can also refer to the relationship between words and dance in Shange's For Colored Girls Who Have Considered the Rainbow When The Rainbow is Enuf or the interaction between the silhouette and the history in Walker's Gone: A Historical Romance of Civil War as it Occurred Between the Dusky Thighs of a Young Negress and Her Heart or the relationship one has with self in Arie's song "Video."

The positive interpersonal relationship that Myers places the "highest value" on has different manifestations in the work that these artists present (182). Yet the idea of the interpersonal relationship is the same: What are the roles of the communicator, and how do the audience interact with it? 


\section{Ntozake Shange's Choreopoem}

Robbie McCauley, a performance artist and scholar who was one of the first actors who performed in for colored girls who have considered suicide when the rainbow is enuf, discusses the potency of the relational interaction in the choreopoem,

The form demands that the performer have an organic, physical relationship to the words and images of the poems/narratives...In order to perform Shange's text, the Actor has to personalize her relationship to it...And, of course, there is a physical life in the text. The actor deals with inner rhythms in giving voice to text.

Shange's work demands that the inner rhythms be physicalized (Lester 4).

Within this brief statement Robbie McCauley has mentioned several interpersonal relationships and the roles within them. The relationship between the performer and the performance (words, images, dance). The actor communicates the performance through the words, images, and dance. However in order for the actor to communicate it effectively, the actor has to have an intimate relationship with the performance through personalization of the creative piece. There is a negotiation that exists between the voice and the text to find the "inner rhythm," and the totality of the performance can be physicalized after the communicated and the communicator understand their roles. This allows a positive interpersonal relationship to occur.

Most of the monologues in For Colored Girls Who Have Considered Suicide When The Rainbow Is Enuf discusses the interpersonal relationships between men and women, from the perspective of women. Lady in Yellow tells a story about the excitement and nervousness of losing her virginity to a boy named bobby and she states "by daybreak i just cdnt stop grinning" (Shange 10). Lady in Red discusses the frustration of 
loving a man who does not love her, "without any assistance or guidance from you, I have loved you assiduously for 8 months 2 wks \& a day" (13). All of the ladies have a part in the monologue that mentions being raped by a male friend, as Lady in Red notes "we cd even have me over for dinner \& get raped in our own houses by invitation a friend" (21). Also Lady in Blue is sadden by a relationship with a lost child through abortion, "get them steel rods outta me, this hurts me" she says when describing the process (22). A story is told about a woman who ritually seduces men and sends them home after the conquest by Lady in Purple (33). Lady in Blue discusses the sadness she feels with herself about being alone in Harlem (38). You find the residue of a cheating man who almost ruined good friendship and a black girl heartache (42-43). If you ever been in a relationship with a man and experienced some type of hardship, you can find it in for colored girls who have considered suicide when the rainbow is enuf. It is the ability of each scene to relate to a diverse group of women that causes audience members to cry and shout for joy. As a patron of the choreopoem, there was witness to how the performance moved the crowd to tears or moments of happiness, it reached the soul affirming the artist work.

\section{Kara Walker's Silhouette Narrative}

The fact that viewers are uncomfortable with Walker's images shows that they have received a message from Walker's silhouette narrative. An uncomfortable reaction could still be considered a positive interpersonal relationship because it gives the communicator feedback. In describing the responses to her work it is acknowledged that "Walker's art cultivates...complex and discomfiting subjection of viewers to a radically destabilizing form of consciousness" (Wagner 93). 
Walker is the communicator and her silhouettes are infused with symbols and history that are communicated. The viewers receive or internalize what Walker has communicated. Myers state "[in] mainstream America, the feedback loop connecting all three is all too often short-circuited, not realizing the value and efficiency of the total interplay..." The value and efficiency of the total interplay is what creates the positive interpersonal relationship. It as an acknowledgement of the multiple "roles that the communicator and listener play as the dialogue continues." Myers continues by attesting, "[i]f the conversation is to be the best possible, both must actively participate."

Walker calls to the viewers through her images and expects you to respond. We have to open ourselves to the experience, to the total interplay and not "restrain ourselves" cause "we are (then) segmenting the process and cannot receive full benefit..." This is why Linda James Myers reminds us to "[l]earn to be free..." In her response to jazz, but relevant to other creative entities, she says "clap when you feel it, acknowledge the spirit, otherwise it will leave you..." (Myers, "Optimal Consciousness" 182).

Through this your consciousness is raised or elevated by fully engaging in this positive interpersonal relationship. When discussing how she was led to a particular style after modernism, Walker indicates her previous experience with art "to thinking about time and history--how we perceive history, how we romanticize history, and at the same time when life and art merge and converge around those conflicts" (Golden 45). Hence Walker is the listener/receiver and history is the communicator and the silence is communicated. 


\section{India. Arie's Song}

As she is walking out her house, viewers notice a glimpse of her back pocket on her blue jeans that says, "Love Yourself." The idea of "loving yourself" will be referenced throughout the whole video. The interpersonal relationship one has with oneself is highly endorsed in her song. The communicator, India. Arie, has directly told her audience what she wants them to do, "Love Yourself." The following lyrics emphasizes this idea of having a positive relationship with yourself,

So get in where you fit in and go on and shine,

Free your mind, now's the time,

Put your sulk on the shelf,

Go head and love yourself

'Cause everything's going be alright (Acoustic Soul).

However, the song was first and foremost about her feelings. How she was able to come and accept the beauty that she possess. While India. Arie is singing to the audience she is simultaneously singing to herself, representing another aspect of the interpersonal relationship in the song "Video". Also the words have its own connection with the artist and the audience that can vary depending on the person experience. Then there is also the fact that India. Arie is a musician, who plays the guitar as she sings "Video" exhibiting a link between her instrument and herself. The interpersonal relationship can be viewed in several ways, depending on how you view it. Shange, Walker, and Arie all exhibit aspects of interpersonal relationships in their art forms, and still others can be revealed. 


\section{CHAPTER VII}

\section{CONCLUSION}

Shange, Walker, and Arie's artistic inventions all manifest optimal consciousness in distinctive ways. The previous chapters demonstrated how selected examples from their work showed authenticity, the fusion of the sacred and secular, and positive interpersonal relationships- the three criteria for optimal consciousness. While exploring these three artists, there were also several other findings that were revealed beside gender and race. Shange, Walker, and Arie have interesting parallels when it comes to their names, backgrounds, relationships to history, and societal reactions. There were even similarities within the cultural movements studied--Harlem Renaissance, Black Arts, and Hip Hop Movement. Therefore, in additional to optimal consciousness this chapter includes unexpected topics that merit mention both in relation to the present topic and that could be furthered explored for future research.

\section{EXTENDED FINDINGS}

Interestingly, all three rebellious artists come from black middle to upper-class families. The artists of the Harlem Renaissance, and the Black Arts Movement, also came from black middle to upper-class backgrounds. They all deviated from their social norms to create their own identity. Ntozake Shange complained about growing up in black middle class and having to go to integrated schools; Kara Walker used black stereotypes that were offensive to the black middle class; while India. Arie chose to be an individual 
regardless of the wealth of her family. It may appear ironic that these popular artists' deviations are the result of their experiences in the black middle class, considering the majority of Blacks would be classified as lowerclass. However the importance of education, consciousness, and critical thinking and their relationship to income should be considered.

Shange, Walker, and Arie also were also all challenged by society. Ntozake Shange's creation of the choreopoem was scrutinized because of its nontraditional structure. The way she wrote the English language in For Colored Girls Who Considered Suicide When The Rainbow Is Enuf was not standard English which caused criticism. She also received harsh reviews because of her negative depiction of men. Kara Walker was banned from several museums. She was verbally attacked by older black artists. She also was ostracized from some black communities for using black stereotypes as her images of choice. India. Arie did not receive any Grammys initially; though she was nominated several times for her song Video that was immensely popular. Alicia Keys took home top honors that year, whose sound and appearance was the opposite of and more popular than India. Arie. This event, however would challenge and inspire Arie's work.

All three of these black women artists changed their name in some form. Ntozake Shange's original name was Paulette L. Williams. India. Arie added a period behind India and dropped her last name Simpson. Kara Walker created an alter ego called The Negress. Also both India. Arie and Ntozake Shange have the word lion inscribed in their name. Arie means lion, and Ntozake Shange signifies one who walks like a lion and brings her own things. 
Linda James Myers expresses that the work can be authentic and still make a profit because "[t]ruth always sells" (Myers, "Optimal Consciousness" 28). Shange, Walker, and Arie are all true to their art forms and are successful not only creatively but financially. Ntozake Shange's play For Colored Girls Who Have Considered Suicide When The Rainbow Is Enuf is still in production while she continues to write books and other plays that are well attended. Matter of fact Tyler Perry is currently making a production of For Colored Girls Who Have Considered Suicide When The Rainbow Is Enuf that is supposed to be released November 2010 (movieinsider). Perry will write, direct, and produce a film version of the well-renowned choreopoem (itzkoff). It will have some the leading African American woman actresses like Whoopi Goldberg, Janet Jackson, and Phylicia Rhasad (lee). Many wait to see if Perry adaptation can match the potency of the play, I guess we shall see.

Kara Walker's silhouettes are shipped all around the world to distinguished museums, and she continues to do local exhibits, write books, and even experiments with film. India. Arie has won several Grammys and has her own record label. These artists did not replicate what was already done; they took their original ideas and made a living.

Though they all represent different artistic vehicles, they all use words. Shange uses poetry while Walker's titles and note cards are full of language, and Arie has her song lyrics. Both Walker and Shange used inventive forms for their artwork. Shange called her form the choreopoem that is comprised of poetry, music, and dance. Walker's work has become known as a silhouette narrative that tells a story.

The work or life of the artists also represented other elements of optimal consciousness. One aspect of optimal consciousness is defining your own reality. Shange 
and Walker defined their own reality by creating their own art form for their creative production. India. Arie defined her own reality by staying true to herself even when she did not win any of the Grammy nominations she got for her song "Video." She went back into the studio and wrote a song called Little Things that discussed how it is family, friends, and cotton that she adores and not the glimmer and glamour of the world.

Along with the discovery of the artist, shedding light on the importance of the Hip Hop Movement to Black culture was also rewarding. Historically the Harlem Renaissance and the Black Arts Movement as cultural movements have received much attentions from researchers studying Black culture- however the Hip Hop movement in which I experienced has also contributed greatly to Black culture. The Hip Hop Movement is also noteworthy in its intersection between art/race/politics/gender and others. Also all these cultural explosions coincided with a war. The Harlem Renaissance began on the heels of World War I. The Black Arts Movement occurred during the Vietnam War, while the Gulf War and the War on Iraq were only some of the wars that co-existed with the Hip-Hop Movement. War seems to also create a space for historical issues with race. My research also provided data that showed how Carribbean immigrants contributed immensely to black nationalism in America.

\section{FUTURE RESEARCH}

Since all these artists are still living, personal interviews with Ntozake Shange, Kara Walker and India. Arie would enhance the study. Since there was difficulty finding information about Neo-Soul music in reference to India. Arie, more extensive work on this genre of music is necessary. Also investigating other black female artists and how they are representative of optimal consciousness like black female playwright Suzan-Lori 
Parks could add to this study because of her incorporation of history, race, class, and gender in her plays. Also now that For Colored Girls is a motion picture created by Tyler Perry, it provides me with more analytically data if I wanted to revisit this research again.

\section{OVERALL EXPERIENCE}

The idea for this research was based on supposition. I knew that the art of India. Arie's work could possibly represent elements of optimal consciousness, but Ntozake Shange and Kara Walker were artists about whom I was not as familiar. I thought that Kara Walker would be the hardest artist to find information about, however I was unaware of her popularity. She had many books and articles written about her making her one of my favorite artists to discover. It also helped that I had access to the $21 \mathrm{c}$ museum in downtown Louisville that housed one of her silhouette exhibits.

To bring three black women artists representing different genres and time periods to the surface in my study was exciting. I learned so much about their unique lives. I even fell in love with history again while reading about the Harlem Renaissance, the Black Arts Movement, and the Hip-Hop Culture. I am happy to be able to have provided a narrative for three talented black women artists whose work represents optimal consciousness.

I am glad to mention that my work is interdisciplinary in nature. I discuss black history, black women history, hip hop, politics and more making it a study that can be beneficial to many. 


\section{REFERENCES}

Addison, Gayle Jr. "Cultural Strangulation: Black Literature And The White Aesthetic". The Black Aesthetic. Ed. Addison, Gayle Jr. New York: Doubleday \& Company, Inc. 1971. 39-46.

Aldridge, Deloris P. "Womanist Issues in Black Studies: Toward Integration Africana Womanist into Africana Studies". Giri So. Ed. Dr. Martin. Louisville: Gray's College Bookstore, 2007. 157-166. Print.

Anderlini, Serena. "Drama or Performance Art? An Interview with Ntozake Shange." Journal of Dramatic Theory and Criticism. Fall 1991: 85-98. Print.

Ani, Mariamba. Yurugu: An African-Centered Critique of European Cultural Thought and Behavior. Trenton: African World Press, 1994. Print.

Asante, Molefi Kete. "Location Theory and African Aesthetics." The African Aesthetic: Keeper Of the Traditions. Ed. Kariamu Welsh-Asante. West Port: Greenwood, 1 1994. 53-62. Print.

Ayanna G. What is Neo-Soul?? 2006. 25 Feb. $2010<$ http://www.associatedcontent.com/ article/66349/what_is_neosoul.html?cat $=33>$.

Baxandall, Rosalyn and Linda Gordon. "Second-Wave Feminism." A Companion to American Women's History. Ed.Nancy E. Hewitt. Malden: Blackwell Publishing, 2002. 414. Print.

Beaulieu-Ann, Elizabeth, ed. Writing African American Women: An Encyclopedia by and about Women of Color. 2 vols. West Port: Greenwood Press, 2006. Print.

Bernier, Celeste-Marie. African American Visual Arts, From Slavery to the Present. C Chapel Hill: The University of North Carolina Press, 2008. Print.

Bullock, Ken. "Poets and Writers Organize Benefit for Katrina Victims." The Berkeley Daily Planet. The Berkeley Daily Planet, 23 June 2006. Web. 23 June 2006.

Burke, Sally. "American Feminist Playwrights: A Critical History". New York: Twayne Publishers, 1996. Print. 
Burnham, Linda Frye. "Listening for the Lexicon of Cultural Shift." Communityarts. Web. March 2010.

Cordova, Jill Cox. "Shange's 'For Colored Girls' Has Lasting Power." Cnn. 21 July 2009 Web. August 2010.

Dixon, Annette. "A Negress Speaks Out, The Art of Kara Walker". Kara Walker, Pictures From Another Time. Ed. Annette Dixon. Ann Arbor: The University of Michigan, 2002. 11-17.

Fisher, James. "Boogie woogie landscapes": The dramatic/poetic collage of Ntozake Shange".Contemporary African American Women Playwrights, A Casebook. Ed.Phillip C. Kolin. New York: Routledge, 2007. 83-98. Print.

Gavin, Christy. "Ntozake Shange." African American Women Playwrights, A Research Guide.Ed. Christy Gavin. New York: Garland Publishing, INC, 1999. 193-243. Print.

Gilman, Sander L. "Confessions of an Academic Pornographer." Kara Walker: My C Complement, My Enemy, My Oppressor, My Love. Ed. By Phillipe Vergne. Minneapolis: Walker Art Center, 2007. 27-36/ Print.

Gleason, Judith. Oya: In Praise of an African Goddess. San Francisco: Harper, 1992. Print.

Hale, Thomas. Griots and Griottes: Masters of Words And Music. Bloomington: Indiana University Press, 1998. Print.

Hodos, Jerome. The Philadelphia Sound. Asanet. July/August 2005 Web. March 2010

Hughes, Langston. "The Negro Artist and the Racial Mountain". The Black Aesthetic. Ed.

Addison, Gayle Jr. New York: Doubleday \& Company, Inc., 1971. 175-181. Print.

Ife, Zadia. "The African Diasporan Ritual Mode." The African Aesthetic: Keeper Of the Traditions. Ed. Kariamu Welsh-Asante. West Port: Greenwood, 1994. 31-51. P Print.

Jegede, Dele. "Art for Life's Sake: African Art as a Reflection of an Afrocentric Cosmology." The African Aesthetic: Keeper of the Traditions. Ed. Kariamu Welsh Asante. West Port: Greenwood 1993. 237-247. Print.

Karenga, Maulana. Introduction to Black Studies. Los Angeles: University of Sankore Press, 2002. Print. 
Lammers, Tim. Alicia Keys Wins 5 Grammys. Indychannel. 27 Feb. 2002. Web Mar. 2010

Lester, Neal A. Ntozake Shange: A Critical Study of the Plays. New York: Garland Publishing, 1995. Print..

Mayfield, Julian. "You Touch My Black Aesthetic and I'll Touch Yours". The Black Aesthetic. Ed. Addison, Gayle Jr. New York: Doubleday \& Company, Inc., 1971. 24-31. Print.

McEvilley, Thomas. "Primitivism in the Works of an Emancipated Negress." Kara Walker: My Complement, My Enemy, My Oppressor, My Love. Ed. Phillipe Vergne. : Walker Art Center, 2007. 53-61. Print.

Myers James, Linda. "The African American Aesthetic As Optimal Consciousness". The African Aesthetic: Keeper Of the Traditions. Ed. Kariamu Welsh-Asante. West Port: Greenwood Press, 1993. 21-29. Print.

Myers James, Linda. Understanding an Afrocentric World View: Introduction to an Optimal Psychology. Iowa: Kendall/Hunt Publishing Company, 1993. Print.

Neal, Larry. "Some Reflections On The Black Aesthetic". The Black Aesthetic. Ed. Addison, Gayle Jr. New York: Doubleday \& Company, Inc. 1971. 13-16.

Nero, Mark Edward. What is Neo-Soul?. About. Web. March 2010

Painter, Nell Irvin. Creating Black Americans: African-American History And Its M Meanings, 1619 to The Present. New York: Oxford University Press, 2007. Print.

Pelton, Robert. The Trickster in West Africa: A Study of Mythic Irony and Sacred Delight. Berkeley: University of California Press, 1980. Print.

Raymond, Yasmil. "Maladies of Power: A Kara Walker Lexicon.” Kara Walker: My Complement, My Enemy, My Oppressor, My Love. Ed. Phillipe Vergne: Walker Art Center, 2007. 347-370. Print.

Richards Marimba, Dona. "The African Aesthetic and National Consciousness." The African Aesthetic:Keeper of the Traditions. Ed. Kariamu Welsh-Asante. West Port: Greenwood, 1994. 63-82. Print.

Richards, Sandra L. "Conflicting Impulses in the Plays of Ntozake Shange". Black American Literature Forum. St.Louis: St. Louis University, 1983. 73-78. Print.

Sander, Gilman L. "Confessions of an Academic Pornographer." Kara Walker: My Complement, My Enemy, My Oppressor, My Love. New York: Walker Art 
Center. 27-36.

Shange, Ntozake. For Colored Girls Who Considered Suicide When the Rainbow Is Enuf. New York, Scribner Poetry, 1977. Print.

Shaw, Gwedolyn Dubois. Seeing the Unspeakable: The Art of Kara Walker. Durham: Duke University Press, 2004. Print.

Strejcek, Ginger. Voyage to India. Seasonmagazine. Winter 2002. Web. March 2010

Swindell, Warren. "Aesthetics and African American Musical Expression." The African Aesthetic: Keeper of the Traditions. Ed. Kariamu Welsh-Asante. West Port: Greenwood, 1994. 175-194.Print.

Takaki, Ronald. A Different Mirror, A History of Multicultural America. New York: Little, Brown And Company, 1993. Print.

Thompson, Betty Taylor. "Ntozake Shange". The Oxford Companion To African American Literature. Ed. Andrews, Foster, Harris. New York: Oxford University Press, 1997.656-657. Print.

Vega, Marta Moreno. "The Candomble and Eshu-Eleggua in Brazilian and Cuban Yoruba-Based Ritual." Black Theatre: Ritual Performance in the African Diaspora. Philadelphia: Temple University Press, 2002. 153-166. Print.

Wagner, Anne M. Kara Walker: "The Black-White Relation." Kara Walker: Narratives of a Negress. Ed. Ian Berry. MIT Press edition, 2003. 91-101. Print.

Waldron, Clarence. "Why India. Arie Is Not Your Average New Girl Singer". Jet. $28 \mathrm{~J}$ Jan. 2002: 58. Print.

Waldron, Clarence. "Hit Singer India. Arie..." Jet. Oct. 2002: 61. Print.

Walker, Kara. "Gone: An Historical Romance of Civil War as it Occurred Between the Dusky Thighs of a Young Negress and Her Heart." Kara Walker: Pictures From Another Time. Ed. Annette Dixon. Anne Arbor: The Regents of the University of Michigan. 51. Print.

Walker, Kara. Art: 21-Stories (Interview). Pbs.Web. March 2010

Walker, Hamzo. "A Mind is a Terrible Thing to Waste (Kara Walker)". Witness to Her Art. Ed.Daniella Rossell and Eau de Cologne. New York: Center for Curatorial Studies, 2 2006. Print.

Wallace, Michele. "Then Enigma of the Negress Kara Walker." Kara Walker: Narratives of a Negress. Ed. Ian Berry: MIT Press edition, 2003. 175-179. Print. 
Welsh-Asante, Kariamu. “ The Aesthetic Conceptualization of Nzuri”. Giri So. Ed. Dr. M Martin.Louisville: Gray's College Bookstore, 2007. 158-177. Print.

Danny Harris (Producer), \& Alan Carter (Director). 2003. India. Arie Live In Brazil [Motion Picture] United States: Tall Pony Productions, Inc.

India. Arie, S. Sanders, C. Broady (2001). Video. Acoustic Soul [CD]. United States: Motown Record Company.

“Top 100 Hits of 2001/ Top 100 songs of 2001”. Musicoutfitters. Web. March 2010.

“Alicia Keys”, Fallen Free Sheet Music. 8notes. Web March 2010

"India.Arie". Headlineentertainment. Web. March 2010

India Arie. Lyricsfreak. Web. March 2010

"Types of Interpersonal Relationships". Novaonline. nvcc. Web. March 2010

"India Arie". Askmen. Web. 2010

"India.Arie Bio". Indiaarie. Web March 2010

"The Griot and African American Poets". Sweet Chariot, the Story of the Spirituals. Web. March 2010.

"Aaron Douglas's Magisterial Aspects of Negro Life." Exhibitions.nypl. Web. March 2010.

"For Colored Girls." Movieinsider. Web. October 2010

"Tyler Perry To Repaint Ntozake Shange's 'Rainbow"' .Dave Itzkoff. Nytimes. Web. October 2010

"A Writer's Struggle, On and Off Page. Felicia R. Lee. Nytimes. Web. October 2010 
APPENDIX A

http://wso.williams.edu/orgs/trivia/mutter/supers/art/image110.jp

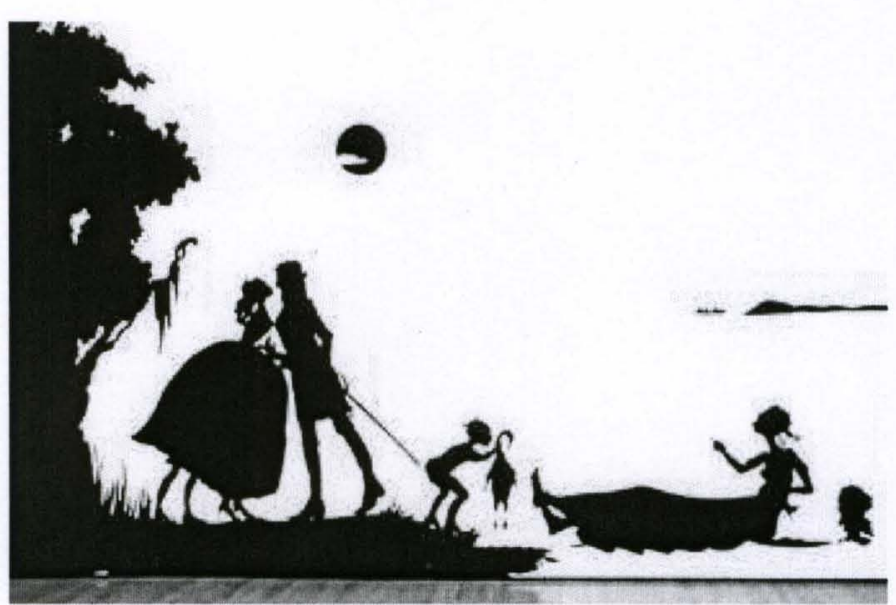


http://www.vestar.com/photos/2008/apr/30/38034

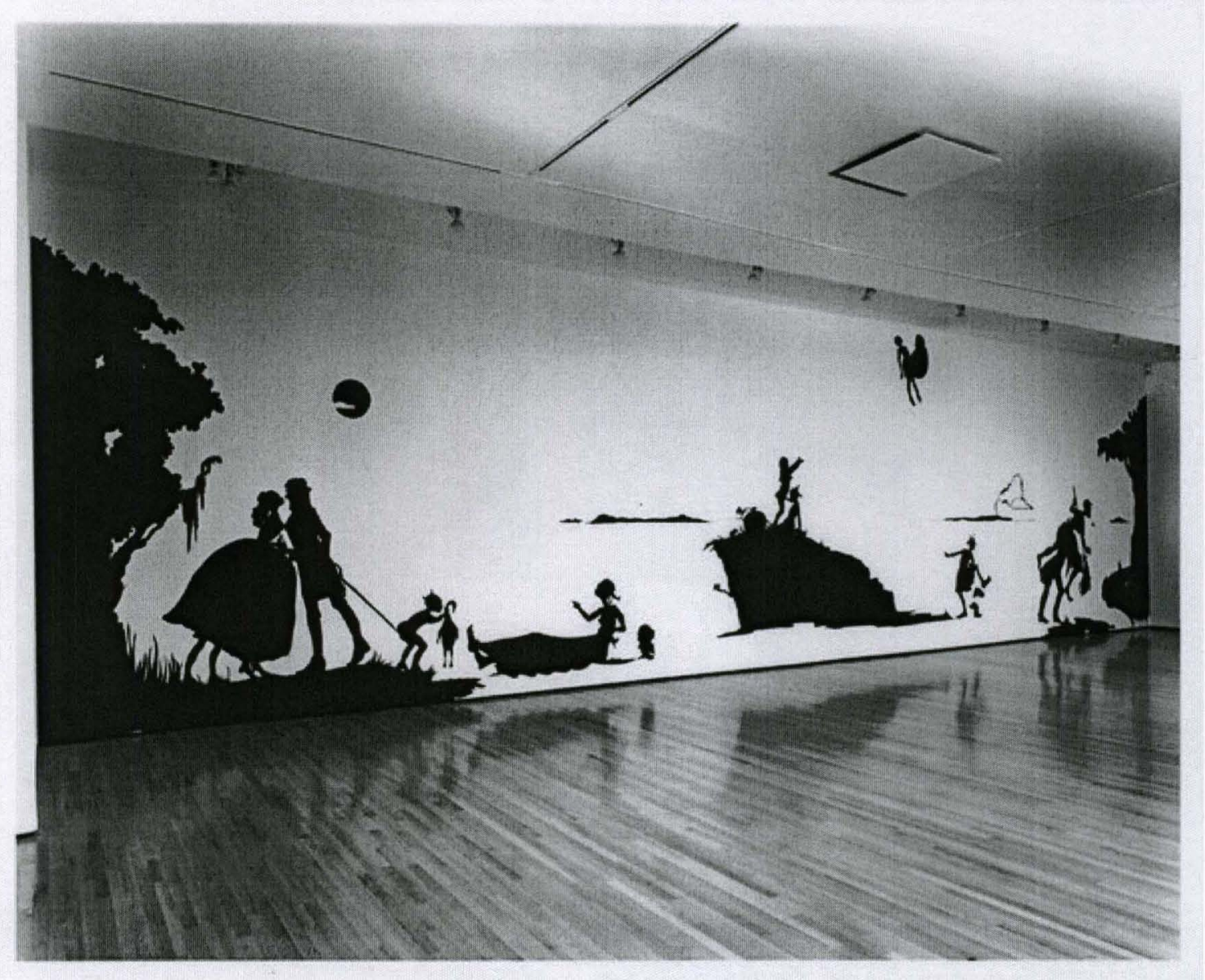




\section{APPENDIX B}

VIDEO (Acoustic Soul) By: India. Arie

Sometimes I shave my legs and sometimes I don't Sometimes I comb my hair and sometimes I won't

Depend on how the wind blows I might even paint my toes

It really just depends on whatever feels good in my soul

\section{(Chorus)}

I'm not the average girl from your video and I ain't built like a supermodel

But, I learned to love myself unconditionally Because I am a queen

I'm not the average girl from your video My worth is not determined by the price of my clothes

No matter what I'm wearing I will always be the india arie

When I look in the mirror and the only one there is me

Every freckle on my face is where it's supposed to be

And I know our creator didn't make no mistakes on me

My feet, my thighs, my lips, my eyes; I'm lovin' what I see

(Chorus)

I'm not the average girl from your video

and I ain't built like a supermodel

But, I learned to love myself unconditionally

Because I am a queen

I'm not the average girl from your video

My worth is not determined by the price of my clothes

No matter what I'm wearing I will always be the india arie

Am I less of a lady if I don't wear pantyhose? My mama said a lady ain't what she wears but, what she knows

But, I've drawn a conclusion, it's all an illusion, confusion's the name of the

game

A misconception, a vast deception
Something's gotta change

but,Don't be offended this is all my opinion

ain't nothing that I'm sayin law

This is a true confession of a life learned lesson I was sent here to share with

y'all

So get in where you fit in go on and shine

Clear your mind, now's the time

Put your salt on the shelf

Go on and love yourself

'Cuz everything's gonna be all right

(Chorus)

I'm not the average girl from your video and I ain't built like a supermodel

But, I Learned to love myself unconditionally

Because I am a queen

I'm not the average girl from your video

My worth is not determined by the price of my clothes

No matter what I'm wearing I will always be the india arie

Keep your fancy drinks and your expensive minks

I don't need that to have a good time

Keep your expensive car and your caviar

All I need is my guitar

Keep your Kristal and your pistol

I'd rather have a pretty piece of crystal

Don't need your silicone I prefer my own

What God gave me is just fine

(Chorus)

I'm not the average girl from your video

and I ain't built like a supermodel

But, I learned to love myself unconditionally

Because I am a queen

I'm not the average girl from your video

My worth is not determined by the price of my clothes

No matter what I'm wearing I will always be india arie 
For Colored Girls Who Have Considered

Suicide When The Rainbow Is Enuf...

Lady in red

i sat up one nite walkin a boardin house

screamin/cryin/the ghost of another

woman

who waz missin what I waz missin

I wanted to jump up outta my bones

$\&$ be done wit myself

Leave me alone

\& go on in the wind

It waz too much

I fell into a numbness

Til the only tree I cd see

Took me up in her branches

Held me in the breeze

Made me dawn dew

That chill at daybreak

The sun wrapped me up swingin rose light everywhere

The sky laid over e like a million men

I waz cold/I waz burning up/ a child

\& endlessly weavin garments for the moon

Wit my tears

I found god in myself
\& I loved her/ I loved her fiercely (Shange 63) 


\section{CURRICULUM VITAE}

NAME: Tiffany Caesar

ADDRESS: 8822 Meadowview

Houston, Texas 77037

DOB: Houston, Texas - April 16, 1985

EDUCATION

\& TRAINING: B.A., English

Truman State University

2003-2008

AWARDS: University of Louisville, Master's of Pan-African Studies

Full Scholarship and Graduate Assistant Stipend 2008-2010

\section{Anne Braden Institute For Social Justice Research, Graduate Assistant}

I assisted in office management, facilitated tours, helped organize and create social justice programs.

October 2008: created and performed "Granny Told Me..." a performance piece that explores Louisville activist Anne Braden and Civil Rights in Louisville

April 2009: Created program entitled Examining the Historical Status of Girls in China in collaboration with the Crane House

November 2008/2009: Anne Braden Memorial Lecture: Helped create and organize a series of events around the guest speaker Barbara Ransby in 2008 and Mike Honey in 2009

November 2009: ACLU Youth Activist Conference at Kentucky State University, performance and lecture

February 2010: Performed "Granny Told Me..." and discussed how performance is used in the community outreach initiative at the Anne Braden Institute at the Shelbyville Conference in a workshop entitled "Building Bridges Between Academy and Community, Research and Action, for Social Justice"

March 2010: "Before You Go To Lunch..." A Commemoration of the $50^{\text {th }}$ Anniversary 
of the Civil Rights Sit-Ins, a program that includes a 10 minute play I wrote about the Civil Rights Sit-Ins in which historian Dr. Hudson also provided a historical background of the movement.

\section{Locust Grove Musuem, Intern}

January-May 2009: Locust Grove Museum: Assisted by helping administration incorporate the African American Slave experience in the museum by creating two short historical plays.

\section{Saturday Academy, Program Assistant}

September 2010- : help create programs for a community outreach program that teaches the community every Saturday on various topics ranging from black history to religion.

\section{Teaching Experiences}

November 2008: Delivered lecture in Dr. Njoku's Ancient African Civilization, topic: Social Institution

November 2008: Co-Taught one class period in Dr. Adam's Introduction to PanAfrican Studies, topic: Black Literature

February-March 2009: Co-Taught and Assisted Dr. Carew with her class entitled African Americans in the American Media topic: Stereotypical Images in the Media and Theatre

May 2009: Co-Taught Dr. Martin's course Introduction to Pan-African Studies topic: Sociology and Creative Production

August-December 2009: Co-Taught Dr. Martin's course Introduction to Pan-African Studies topic: Sociology and Creative Production*

\section{Other}

April 2009: SIRAS Conference-Presented my research entitled-India. Arie Black Aesthetics Revisited Through A Contemporary Artist at Kentucky State University

July 2009: Study Abroad: Trinidad and Tobago

\section{Publications}

"It Doesn't Quite Translate... The Relationship Between Africans and African Americans on the Truman State University Campus", The McNair Scholarly Review 2007 


\section{Professional Development and Performance}

“Granny Told Me...” Fall 2008- : Louisville, Kentucky

An original performance piece created for the Anne Braden Institute For Social Justice.

Research to discuss the significance of local activist Carl and Anne Braden through the eyes of a young student. It was performed at the following venues:

- The Anne Braden Institute For Social Justice Research

- University of Louisville: class entitled Women in American Culture

- The Frazier Museum : Civil Rights Teach-In (Performance accompanied by lecture and activity)

- ACLU Youth Activist Conference : Civil Rights-Teach-In

- Dosker Manor Retirement Home

- Brown Middle School

- First Unitarian Church

- Shelbyville Campus- Teaching and Learning Workshop "Building Bridges Between Academy and Community, Research and Action, for Social Justice: The Anne Braden Institute"

\section{An Afternoon of Freedom and A Dream of Freedom, York and Bishop: Locust Grove} Museum Spring 2009: Louisville, Kentucky

I helped administration highlight the African American slave experience by creating two historical plays for museum theatre. I also performed in it and assisted as the director of the performance under Dr. Lundeana Thomas. They were performed at these following events:

- The 18th Century Thunder Reenactment by professional actors

- Antebellum Louisville Conference Muhammad Ali Center

Vagina Monologue Spring 2009: Louisville, Kentucky

- I performed the piece called "The Little Coochi Snoorcher That Could"

“We Is We...” Summer 2009: Trinidad and Tobago

- Directed and Co-Wrote a performance for the University of West Indies in Trinidad that discussed students from the University of Louisville study abroad experiences.

Cornered in the Dark Fall 2009: Louisville, Kentucky

I participated in an original choreopoem by performance artist Lenelle Moise that 
discussed women abuse presented at the following locations:

- Take Back The Night Program, University of Louisville

- Jefferson Community and Technical College

Martin Luther King Day Celebration Spring 2010: Louisville, Kentucky

I performed in a theatrical pageant about famous black people in Kentucky as Alice Dunnigan famous African American journalist, written and directed by Dr. Lundeana Thomas.

"Before We Go To Lunch..." A Commemoration of the Civil Rights Sit-In Spring 2010: Louisville, Kentucky

A program in which I wrote, directed, and performed a 10 minute play about the Civil Rights Sit-ins. It will be followed by historical perspective from Dr. Hudson.

TRAINING:

2003-2008-BA in English

2008- Master's in Pan-African Studies with Graduate Certificate in African American Theater

Classes/Workshops: Actor's Workshop 2010- at the University of Louisville by ZanSawyer Dailey

Acting, Performance and Community 2010- the University of Louisville by Dr. Amy Steiger

\section{SPECIAL SKILLS:}

I have experience in taking history and using it to create performances used for public history in venues like museums and schools. I have taught several classes in the PanAfrican Studies department at the University of Louisville, with special interest in cultural productions. 